IZA DP No. 7171

Is Self-Esteem a “Double Edged Sword"?

Self-Esteem and the Onset of Adolescent Sexual Activity

Marta Favara

January 2013 


\title{
Is Self-Esteem a "Double Edged Sword"? Self-Esteem and the Onset of Adolescent Sexual Activity
}

\author{
Marta Favara \\ ISER, University of Essex \\ and IZA
}

\author{
Discussion Paper No. 7171 \\ January 2013
}

IZA
P.O. Box 7240
53072 Bonn
Germany

Phone: +49-228-3894-0

Fax: +49-228-3894-180

E-mail: iza@iza.org

\begin{abstract}
Any opinions expressed here are those of the author(s) and not those of IZA. Research published in this series may include views on policy, but the institute itself takes no institutional policy positions. The IZA research network is committed to the IZA Guiding Principles of Research Integrity.

The Institute for the Study of Labor (IZA) in Bonn is a local and virtual international research center and a place of communication between science, politics and business. IZA is an independent nonprofit organization supported by Deutsche Post Foundation. The center is associated with the University of Bonn and offers a stimulating research environment through its international network, workshops and conferences, data service, project support, research visits and doctoral program. IZA engages in (i) original and internationally competitive research in all fields of labor economics, (ii) development of policy concepts, and (iii) dissemination of research results and concepts to the interested public.
\end{abstract}

IZA Discussion Papers often represent preliminary work and are circulated to encourage discussion. Citation of such a paper should account for its provisional character. A revised version may be available directly from the author. 


\section{ABSTRACT \\ Is Self-Esteem a "Double Edged Sword"? Self-Esteem and the Onset of Adolescent Sexual Activity}

Self-esteem has been conceptualized as a "social vaccine". The belief is that high selfesteem can inoculate young people, against vulnerability to a wide range of social illnesses. This study gives a contribution in the understanding of the causal relation between selfesteem and sexual behaviour among American adolescents. I analyzes the impact of different levels of early self-esteem on a wide set of risky sexual behaviours. I use data from the National Longitudinal Study of Adolescent Health and I take into account the endogeneity of self-esteem using instrumental variables methods and measuring self-esteem before sexual initiation. I find that self-esteem over a certain threshold' is a protective resource for girls, delaying the onset of sexual activity, reducing the number of occasional sexual partners and increasing the likelihood of having protected sexual encounters.

JEL Classification: I12, J13, O51

Keywords: self-esteem, adolescent's sexual behaviour, Add Health, instrumental variable model

Corresponding author:

Marta Favara

Institute for Social \& Economic Research (ISER)

University of Essex

Wivenhoe Park

Colchester, Essex CO4 3SQ

United Kingdom

E-mail: mfavar@essex.ac.uk

\footnotetext{
* I would like to thank Cheti Nicoletti and Mark Bryan for the extensive discussion, John Ermisch and Pr Gustafsson for their valuable comments and the participants at ISER PhD seminars and at the Health, Development and Inequality Conference (Darmstad, 2010) for their helpful suggestions. All mistakes are the author's only responsibility.
} 


\section{Introduction}

The high number of unintended teen pregnancies and the prevalence of sexually transmitted diseases (STDs) among American adolescents have led to a number of sexual health programs. Sexual initiation is considered a crucial step to adulthood because of the risky choices it can involve. Teenage sexuality has become a major area of policy concern after many studies show that adolescents who have sex before sixteen are less likely to use contraceptives and more likely to contract STDs and become teenage parents.

Risky sexual behaviours are often a manifestation of deprivation and poverty. Previous studies have found significant associations between early sexual activities and family characteristics such as disadvantaged socio-economic background, low parental education, large household size and unstable family environment (Kahn et al., 1988; Miller and Moore, 1990; Pick and Palos, 1995). Furthermore, it has been observed that scarce family resources are associated with low self-esteem (Amato and Chiltree, 1986; Alexander, 2001; McLoyd 1990; Caspi and Elder, 1988; Whitbeck et al., 1991). This study suggests selfesteem as an important channel through which family characteristics and within-family relationships influence sexual behaviour.

This chapter recognises that self-esteem can be simultaneously cause and effect. Branden argues that "the level of our self-esteem influences how we act, and how we act influences the level of our self-esteem. [...] Causation flows in both directions" (Branden, 1994, pp.4). Although a consistent part of literature focused on self-esteem as a social product, i.e. as a consequence of social influences, the association between self-esteem and juvenile deviant behaviour has also been explored (McGee and Williams, 2000). Even so, the influence of early self-esteem on the onset of adolescent sexual activity has not received as much attention as it deserves.

This chapter takes the previous research a stage further deepening our understanding of the role of self-esteem in adolescent sexual initialization. The purpose of this investigation is to analyze the impact of different levels of early self-esteem on a set of risky sexual behaviours which I will call "sexual outcomes": premature sexual initiation, number of sexual partners during adolescence, use of condom and birth control methods and the likelihood to be affected by STDs.

To the best of my knowledge, previous research documents the association between selfesteem and sexual behaviours using cross-sectional data and they are unable to test a causal relation between self-esteem and sexual outcomes. In order to disentangle the reverse causality issue I use instrumental variable models and longitudinal data from the National Longitudinal Study of Adolescent Health (Add Health) specifically designed to study American adolescents' health and risk behaviours. 
This chapter tests the hypothesis that both very low and very high level of self-esteem might increase the likelihood to engage in risky behaviours. Some psychologists and social scientists debunked the myth of self-esteem as an "all-purpose social vaccine" recognizing that young people with very high self-esteem are more likely than others to engage in risky behaviours (Emler, 2001; Baumeister, 1996; Baumeister et al., 1996). They conclude that both high self-esteem and exceptionally low self-esteem might be harmful and they highlight the benefits of moderation.

Taking that into account, I test the presence of a non-linear relationship between selfesteem and sexual outcomes. The first hypothesis I test is that children with high selfesteem are healthy and more prudent adolescents in term of sexual attitude. In this sense, self-esteem acts as a protecting resource. The second hypothesis is that extremely high or low levels of self-esteem may act as risk enhancing factors. In this case, selfesteem may be a "double edged sword". Too much self- esteem might negatively affect adolescent sexual behaviour. The chain of causality may run through a variety of routes: extremely high levels of self-esteem may lead young people to underestimate the dangers or to overestimate their own abilities to deal with risky situations, increasing sexual transgression.

Additionally, I seek to understand whether and to what extent the relationship between self-esteem and sexual onset varies across ethnic groups and gender. Empirical evidence suggests that black adolescents adopt riskier sexual behaviour relative to their white counterparts. Traditionally, it is attributed to the disadvantaged socio-economic position of black population in most western societies. Many studies show considerably higher self-esteem scores among blacks compared with whites and similarly boys have higher selfesteem than girls. However, high levels of self-esteem within black male population have been found to be positively correlated with the likelihood of engaging in risk behaviour. I investigate if there are gender and ethnic differences in the way that self-esteem affects sexual behaviour and partly contributes to this diversity, after controlling for an extensive set of confounding factors.

In short, three are the innovative contributions of the present investigation. First, it analyzes comprehensively the causal pathway between early self-esteem and a wide set of later sexual outcomes among race and gender-specific subgroups of adolescents. Second, it tests the hypothesis that both very high and low levels of self-esteem enhance the probability to engage in risky behaviours. Finally, the use of longitudinal data and the adoption of instrumental variable methods to deal with the reverse causality issue and self-esteem endogeneity allow moving a step further in identifying causality. 


\section{Background}

According to data from Centers for Disease Control and Prevention, in 2007 almost half of U.S. students enrolled in 9th-12th grade reported having had sexual intercourse. Sexually active adolescents are known to be at risk of unwanted pregnancy and of contracting a number of sexually transmitted diseases including HIV infection (Bingham, 1989; D'Augelli et al., 1993). Despite encouraging downward trends, United States is one of the Western industrialized nations with the highest incidence of teenage pregnancy. More than 30 percent of teenage girls in the U.S. have already become pregnant by the age of 20 (Kirby, 2007). Early motherhood is associated with worse educational and occupational attainments, lower income, and marital instability. ${ }^{1}$ Children of teenage parents face poorer infant health, lower academic achievement, higher risk of socio-emotional problems, and a greater probability of becoming teen parents themselves. Furthermore, children of teen mothers are a third more likely to be born prematurely and more likely to be underweight (Geronimus and Korenman,1993; Francesconi, 2008; Conde-Agudelo et al., 2004; Chen et al., 2007; Levine et al., 2001). Low birth weight and premature birth raise the probability of a number of adverse conditions, including infant death and mental retardation.

Each year, there are approximately 12 million new cases of sexually transmitted diseases $(S T D s)$ in the United States (American Social Health Association, 1998). STDs prevalence is 30 percent higher for blacks than for whites (Centers for Disease Control and Prevention, 2000a). In 2000, 15-19 year-old black males had a rate of gonorrhea that was about 20 times the rate of white males in the same age group (Centers for Disease Control and Prevention, 2000b). Chlamydia rates among African American males ages 15 to 24 were 12 times higher than rates among young white males. HIV infection is also more prevalent among black male adolescents than among whites (Centers for Disease Control and Prevention, 2002). There are reasons to think that the high rate of unintended pregnancy and STDs are due to irresponsible behaviours, sexual promiscuity, and insufficient

\footnotetext{
${ }^{1}$ However, many empirical studies fail in ascertaining causality because they inadequately account for confounding factors and teenage pregnancy endogeneity (Ashcraft and Lang, 2006). They do not take into account that teen mothers are usually more likely to have disadvantaged socio-economic background which might imply both a higher probability to become pregnant as adolescent and poor outcomes, such as educational failures or unemployment.
} 
or inappropriate use of contraceptive methods.

To reduce the incidence of teenage pregnancy and STDs, many proposed interventions emphasize the factors influencing adolescent behaviour. According to this approach, interventions should be directed to change adolescents' aspirations, increase the intention to use contraceptive methods, enhancing self-efficacy of condom negotiation and condom use (Santelli et al., 1999; Salazar et al., 2005). Salazar and colleagues suggest that a factor "[...] that may influence female adolescent sexual behaviour is the concept of self" (Salazar et al., 2005, pp.415). They find a significant relation between self-esteem and a set of determinants of safer sexual behaviour (i.e. condom attitudes, perceived barriers to condom use, peer norms, self-efficacy of condom use negotiation) once controlling for a set of covariates. Higher self-esteem positively correlates with the negotiating power over condom use and leads to less risky sexual conduct.

The debate on self-esteem and adolescent risky behaviour has been informed mainly by the sociological and psychological literature. However, a recent branch of the economic literature has been interested in studying the role of the "Big Five" personality traits for economic outcomes. ${ }^{2}$ Although self-esteem is not one of the Big Five traits and most of research on self-esteem is carried on without referring to the Big Five taxonomy, selfesteem has been recognized as closely related to them and in particular to "neuroticism" (Judge et al. 2002; Judge and Hurst, 2007). ${ }^{3}$

Several studies suggest that personality traits predict a variety of outcomes including educational attainments, labour market outcomes and risky behaviors. ${ }^{4}$ For example Heckman et al. (2006) find that self-esteem and locus of control measured during adolescence are as powerful as cognitive abilities in predicting adult earnings. Moreover, they find that personality factors for men affect the probability of daily smoking more than cognitive factors and the opposite is true for women. Similarly, Cunha et al. (2010) show that personality traits are relatively more important in predicting criminal activity than

\footnotetext{
${ }^{2}$ The "Big Five" factors of personality (openness, conscientiousness, extraversion, agreeableness, neuroticism) are five broad domains or dimensions of personality identified to describe human personality. The Big Five have been defined as the longitude and latitude of personality, by which all traits may be categorized (Costa and John, 1992).

${ }^{3}$ Neuroticism is defined as a chronic level of emotional instability and proneness to psychological distress (Costa and McCrae, 1992).

${ }^{4}$ See the evidence collected in Almlund et al. (2011) and Borghans et al. (2008)
} 
cognitive traits are. Further, Conti and Heckman (2010) suggest that personality and health status measured during adolescence explain more than 50 percent of the difference in poor health, depression, and obesity at age 30. For male, personality traits and health endowment are more predictive than cognitive skills while for women they are equally predictive.

In the sociological literature, self-esteem has been conceptualized as a "social vaccine". The belief is that high self-esteem can inoculate people, especially young people, against vulnerability to a wide range of social illnesses. Past research studies found that prior low self-esteem is predictive of subsequent reports of a range of "health-compromising" behaviours in youth such as substance abuse, smoking, unprotected sex, criminal behaviours, early sexual activity, early pregnancy, eating problems and suicidal ideation, juvenile delinquency, personality disorders and psychological depression (McGee and Williams, 2000; Wells and Rankin, 1983). In this sense, self-esteem is a protective factor (Friedman, 1989; Zimmerman et al., 1997). It both prevents and protects against risks but also enhances "the psychological resources on which individuals may draw to deal with stressful situations" (Longmore et al., 2004).

Most previous studies provide simple correlations between outcome variables and selfesteem, controlling for other covariates, and it is not clear whether self-esteem is primarily the cause or the effect of a list of correlated outcomes (Lehrer et al., 2006; Robinson and Frank, 1994; Spencer et al., 2002; Salazar et al., 2005).

A number of studies have found that sexually active adolescents are more likely to suffer from depression and low self-esteem than peers who delay first intercourse (Spencer et al., 2002; Orr et al., 1989). Indeed, early sexual activity and multiple sexual partners often end up with the dissolution of a romantic relation and unintended pregnancy or sexually transmitted infection (Larson et al., 1999; Joyner and Udry, 2000; Meier, 2007; Ayduk et al., 2001, Grello et al., 2003, and Davila et al., 2004). These events influence mental health in the transition from adolescence to adulthood (Meier, 2007; Hallfors et al., 2005; Rector et al., 2002).

Conversely, few studies look at self-esteem as a determinant of adolescent sexual behaviour (Salazar et al., 2005; Robinson and Frank, 1994). Among these studies, Jessor and Jessor 
(1975) using longitudinal data collected for high school students found that higher levels of pre-existing self-esteem were predictive of the transition to sexual activity for boys. Spencer and colleagues (2002), using data collected longitudinally, show that girls who scored low on the self-esteem measure and boys who scored high on self-esteem are more likely to initiate coitus during the subsequent year.

Early empirical studies documented significant gender and racial sexual behaviour differences among teenagers (Zelnik et al., 1981). Theoretical explanations of gender differences in the onset of sexual activity tend to emphasize biological and physical development differences, differences in social control and parental supervision for males and females and differences in risk aversion and in the higher opportunity cost of being sexually active for girls than for boys (for example, in terms of unintended pregnancy).

Together with gender, ethnicity is another central factor in explaining the initiation of sexual activity and a number of other sexual outcomes. Although this difference is diminishing, more recent studies confirm that race still has a significant effect on the age at voluntary sexual initiation and the number of partners (Ku et al., 1993). Blacks are more likely than adolescents of other races to have multiple partners (Anderson and Dahlberg, 1992; Durbin et al., 1993; Smith, 1991) and to initiate sexual activity earlier (Coker et al., 1994; Hofferth et al. 1987; Kinsman et al., 1998). One possible explanation is the disadvantaged economic position of black population and a set of circumstances that are associated with race (single-parent families, lower parental education, and poor education performance of the child) and with early sexual intercourses and risky sexual attitudes (Furstenberg et al., 1987; Dryfoos 1990; Newcomer and Udry 1987). Another possible explanation reflects the presence of culture-specific sexual norms and socially recognized values in motivating the timing of sexual initiation and in regulating adolescent sexual behaviour in general. Differences between blacks and whites in the optimal perceived scheduling of life course events are well documented as well as it is recognized that blacks have more tolerant attitudes about early childbearing, weakening the deterrent to teenage sexual activity (Smith and Udry, 1985; Coker et al., 1994; East, 1998). 


\section{Data and variables}

\subsection{Sample description}

The data used in this study come from the first three waves of the National Longitudinal Study of Adolescent Health (Add Health). Add Health was specifically designed to study adolescents' health and risk behaviours.

Data were gathered from interviews with children at home (the in-home questionnaire) and at school (the in-school questionnaire), interviews with children's step or biological parents and with school administrators. The home questionnaire contained a young person section and a main parent section. The preferred parental respondent was the biological mother or other female guardian (step mother or grandmother) rather than the biological or step father or other male family members. ${ }^{5}$ In 85 percent of the cases, the main parental respondent is the biological or the step mother.

Data was collected in 80 high schools in the United States. Most were then matched with a junior high or middle school from the same community, bringing the total number of participating schools to 132, including 90,118 students in total. For these children only data gathered from interview at school are available. From the student rosters of these 132 schools, a random sample of 20,745 students enrolled in grades 7-12 were interviewed at home in 1994-95 (Adolescent Health Wave I). The Wave II was conducted approximately one year later and it consists of interviews with 14,738 of the Wave I respondents. Interviews with 15,170 Wave I respondents were completed at Wave III. The Wave III sample consists of Wave I respondents who could be located and re-interviewed six years later. ${ }^{6}$ Interviews were conducted in 2001-2002 when the sample was aged 18-26.

In the present study variables concerning self-esteem, family background, child's characteristics and within-family relationships come from Wave I and Wave 2, while information about sexual outcomes comes from Wave III. These data are available only for those participants interviewed both at home and school.

\footnotetext{
${ }^{5}$ According to previous studies, mothers are generally more familiar than fathers with the schooling, health status, and health behaviours of their children.

${ }^{6}$ It results in a 77.4 percent response rate.
} 
I restrict the sample considering only those respondents that have never had a sexual intercourse before in order to avoid potential reverse causality between self-esteem and the sexual behaviour. Doing this, I exclude from the analysis 25 percent of Wave 1 respondents. Compared to those adolescents who are still virgin, those having sex before the first interview had sex for the first time earlier (14.2 years old vs. 17 years old), are more likely not to use contraceptive (for example, 67 percent of them against 57 percent never or just occasionally use condom) and, being 1.5 years older, had sex with almost double the number of partners (11 versus 6$)$. On average they come from a poorer socioeconomic background (they have lower household income, low educated parents, they are more likely to live in a single headed household) and they have lower self-esteem, which might be either a cause or a consequence of the early sexual initiation.

Since it makes sense to define the dummy variables for whether a child have been diagnosed with at least one STD, uses birth control methods and uses condoms only for children who are already sexually active, I exclude from my sample all those adolescents who are still virgin at Wave 3 (about 11 percent). I use this restricted sample also when considering the number of sexual partners and the age at first sexual intercourse. ${ }^{7}$ The final sample counts about 5,700 white and black adolescents having information on sexual outcomes and with a measure of self-esteem available before sexual initiation (Table 1). ${ }^{8}$

In this section I describe the variables used and I present some weighted descriptive statistics of the final sample by gender and ethnic group. ${ }^{9}$ In the last column of each table I report results from two sample t-tests for a difference in means between the two subsamples compared. The composition of the sample considered for the present analysis is showed in Table 1. The panel A of Table 1 reports the mean and standard deviation of

\footnotetext{
${ }^{7}$ Arguably, this truncation might generate selection bias given that the decision to have sex or to delay the sexual debut may depend upon characteristics which are not randomly distributed across the population. The adolescents who are still virgin when last observed are on average almost one year younger, they have significantly higher self-esteem, higher income but they are more likely to have low educated parents and live in a single-headed household. I did some sensitivity analysis to check for potential selection bias controlling in the model estimated for the predicted probability to lose virginity before age 17 (and 18) and in most of the cases the results are qualitatively similar.

${ }^{8} \mathrm{I}$ also tried to identify pairs of siblings for which the in-home questionnaire was available. However, because of the reduced number of sibling pairs included in the dataset and the numerous missing data, I ended with a small size sample which makes any kind of analysis impossible.

${ }^{9} \mathrm{I}$ use grand sample longitudinal weight specifically designed to adjust for the Add Health sample design, which intentionally oversampled some population subgroups (http://www.cpc.unc.edu/projects/addhealth/data/guides/weights.pdf).
} 
the age and ethnic composition for the subsample of boys and girls. Similarly, the mean and standard deviation of the age and the gender composition are reported by ethnic group in panel B of Table 1. In the other tables I report the mean and standard deviation of the sexual outcomes by gender (Table 2, Panel A) and by ethnic group (Table 2, Panel B) and the same statistics for self-esteem (Table 3, Panel A and B). Table 4 shows all the control variables used in the multivariate analysis as described below.

\subsection{Outcomes variables}

I study adolescent sexual behaviour measured by five outcome variables: age at first sexual intercourse, number of sexual partners ever had, use of birth control methods, use of condom, and the likelihood to be diagnosed with at least one STD in the past year (Table 2). ${ }^{10}$ The set of outcome variables was constructed using information from in-home child questionnaires in Wave III.

The first outcome variable is the age at first sexual intercourse. This information is contained in all waves' questionnaires. In case of missing data in Wave III, I use information from Wave II when available. The second outcome variable is a measure of adolescent sexual promiscuity, defined as the number of sexual partners had. The third outcome variable is a measure of the risk of contracting a STD. The dependent variable takes value 1 if the male partner never or only occasionally used a condom in the past year and 0 otherwise. ${ }^{11}$ The fourth outcome variable is a dummy for whether any form of birth control or pregnancy protection has been used in the past 12 months. ${ }^{12}$ It takes value 1 if the adolescent and his/her partner never or only occasionally used them and value 0 if they protected themselves in most or all occasions. The last variable is a dummy variable taking value 1 if he/she has been diagnosed with at least one STD in the past 12 months and value 0 otherwise.

On average, there are no significant differences in the age of sexual initiation between boys

\footnotetext{
${ }^{10}$ See Appendix A1 for the specific questions used in the present analysis to depict adolescent sexual outcome.

${ }^{11} \mathrm{I}$ also considered a measure of the number of STDs contracted in the past 12 months.

${ }^{12}$ Birth control methods include: birth control pills, implant, depo provera, diaphragm, emergency contraception or the morning after pill, natural family planning, female sterilization and condom.
} 
and girls (Table 2, Panel A). Most of the adolescents had their first sexual intercourse between 15-18 years. At 15 years old 23 percent of the female population has already experienced sexual intercourse (against 19 percent of male population) and 83 percent of girls and 81 percent of boys had sex before age 18 .

Concerning the number of sexual partners, girls are less promiscuous than boys: on average by the age of 18 girls and boys have had sex with the same number of sexual partners (3-4 partners), but by the age of 22 boys report a higher number of sexual partners than girls (4-5 partners for girls and 5-6 partners for boys) (see Table 2, Panel A).

Differences between boys and girls are more evident looking at the contraceptive use. Females had riskier sex in the past year than boys (see Table 2, Panel A). In 62 percent of cases their partners never or only occasionally used a condom (against 52 percent of interviewed boys). Compared to boys, girls are diagnosed with STD more frequently: 15 percent of them (against 4 percent of boys) had at least one STD in the past year.

Rates of sexual activity vary considerably by ethnicity (Table 2, Panel B). Blacks start having sex earlier than white adolescents (24 percent of black adolescents start at the age of 15 against 20 percent of white adolescents and 88 percent of blacks versus 80 percent of white adolescents have the first sexual intercourse before age 18) and by the age of 22 they have had sex with a larger number of partners.

Black adolescents adopt a riskier sexual behaviour than white boys: 37 percent never used birth control methods (against 26 percent of whites) and 16 percent of them has contracted at least one STD during the last 12 month period (against 8 percent of whites). Blacks are more prudent only in the use of condoms: 52 percent of them always or in most of occasions use condoms, compared to 39 percent of whites (see Table 2, Panel B).

\subsection{Self-esteem}

As a measure of self-esteem, I follow Rosenberg (1965) Self-Esteem Scale (RSE), which is the most popular and utilized measure of self-esteem. The RSE is usually based on 
10 items. The Add Health study administered 2 of the 10 questions typically used to derive these 10 items (statement 1-2, as listed below), and it also includes four additional questions (statement 3-6, as listed below) which can provide good proxies of other RSE items (Bankston and Min Zhou, 2002). Specifically, children in Add Health are asked to report how much they agree with each of the following statements:

1. I feel that I have a number of good qualities;

2. I have a lot to be proud of;

3. I like myself just the way I am;

4. I feel socially accepted;

5. I feel I am doing everything just about right;

6. I feel loved and wanted.

Responses can take the following values: "strongly agree" $(=4)$, "agree" (=3), "neither agree nor disagree" $(=2)$, "disagree" $(=1)$, or "strongly disagree" $(=0)$. I created a single scale from these items scores ranging from 0 to 24 . Several empirical studies confirm the reliability of RSE as measured by Cronbach's alpha. ${ }^{13}$ The scale generally has a Cronbach's alpha in the range of 0.77 to 0.88 for various samples (Rosenberg, 1986). The Cronbach alpha coefficient for the 6 -items scale used in this study is 0.84 , indicating a high level of reliability.

On average, boys have higher self-esteem than girls (Table 3, Panel A). The percentage of girls with self-esteem below the 25 th percentile in the sample is one third higher than the percentage of boys (36 percent against 23 percent, respectively). On the contrary 24 percent of boys (against 17 percent of girls) are on the top of the self-esteem distribution (i.e. with self-esteem above the 75 th percentile).

\footnotetext{
${ }^{13}$ The Chronbach's alpha is a statistic commonly used as a measure of the reliability of a psychometric instrument. It indicates how well the linear combination of a set of items measures a single latent dimension. It is computed as the ratio of the variance of the observed total test scores, and the variance of each component. It takes a value which approaches to 1 in the case of perfect reliability. Generally an alpha equal to or higher than 0.70 is the most common rule of thumb signalling the reliability of the index computed. Higher values of alpha are more desirable (Chronbach, 1946 and 1950).
} 
On average, black children have higher self-esteem than white children. Looking at the extreme values of the self-esteem distribution, 18 percent of white children against 24 percent of blacks have high self-esteem (above the 75th percentile), while 33 percent of white children against 24 percent of black children have low self-esteem (below the 25th percentile).

Considering that self-esteem is the product of reflected appraisals (how one is viewed or evaluated by society), self-perception, and social comparison, one would expect that disadvantaged and minority groups in a society experience lower levels of self-esteem (Rosenberg and Pearlin, 1978). Past theories about racial segregation and discrimination suggested that people segregated and rejected by their society have lower self-image and self-confidence. Thus, the expectation is that the social order should reflect individual self-assessments. Nevertheless, consistent with previous empirical studies these descriptive statistics show that black children, belonging to families with lower socio-economic profiles, have higher self-esteem than whites. A number of theories, including those related to self-protection and misidentification, have been offered to explain these findings (Crocker et al., 1991). Rosenberg and Simmons (1972) find that socio-economic status seemed to have a relationship with white children's self-esteem, but not with blacks'. They argued that "black children have little awareness of how low their socioeconomic status in society really is".

\subsection{Control variables}

I consider a wide set of control variables which I define below, including family socioeconomic background, household composition, parenting style, religion, child demographic characteristics, school attainment and health (Table 4). As for self-esteem measure, all variables regarding the child's background comes from Wave I.

\section{Family socio-economic characteristics}

Family income is the amount of household income reported by the main parent in the parent questionnaire and it is used as a continuous variable. Additionally, I control for 
household size as an indicator of the economic resources available to each individual in the household.

The presence of economic stressors in the family is measured by a dummy variable which takes value 1 if the respondent parent reports having problems or not enough money to pay bills and 0 otherwise.

Parental education is a categorical variable measured as the highest educational level achieved by the mother or the father; it takes value from 0 for those who did not get a high school diploma, 1 for those who got some secondary education but did not graduate and 2 for those who graduated or pursue in post-secondary education. Among blacks 9 percent of parents (against 5 percent for whites) have less than high school qualification (Table 4, Panel B).

As a measure of occupational status, I use the main parent's employment status which takes value 1 if the parent reports being employed full time and 0 otherwise. In our sample, on average, 60 percent of main parents are employed full time, while 40 percent of them have either a part-time job, are unemployed or are out of the labour force.

Previous studies found that family disruption affects both adolescent sexual behaviour (Miller and Bingham, 1989; Thornton and Camburn, 1987; Young et al., 1991) and selfesteem (Bachman, 1970; Rosenberg, 1965; Thomas et al., 1974). Adolescents from intact two-parent families delay the start of sexual activity relative to those in disrupted families (Laumann et al., 2000; Meschke and Silbereisen, 1997; White and DeBlassie, 1992; Miller and Moore, 1990; Thornton, 1991). A possible explanation could be the general loss of control in single-parent families related with lower level of parental supervision, monitoring and the provision of a less stable environment which is indirectly connected with a lack of parental rules or transmission of values.

Children who live in single-parent families show more behavioural problems and lower self-confidence (Dorbusch et al., 1985; Fergusson et al., 1986; Luster and McAdoo, 1994; Steinberg, 1987). These findings could be explained by the economic deprivation often experienced in single-mother families (Conger et al., 1994; Duncan et al, 1994; Elder and Caspi, 1988; Hashima and Amato, 1994), but also by the importance of paternal presence 
in the children's socialization process (Teachman et al., 1998; Cooksey and Fondell, 1996).

In my model, family structure is categorized as a single-parent family, two-parent family or no residential parent family (with no parent living in the household). On average, 28 percent of children have only one parent. This rate is much higher for blacks (45 percent) than for whites (21 percent).

\section{Child characteristics}

As an indicator of child cognitive skills I use the mean grade obtained in maths, science and history collected in Wave 1 and referring to the most recent grading period. In order to minimize the missing values and reduce inconsistencies, I use information from both questionnaires the in-home and in-school questionnaire. I recoded the response category from 4 (corresponding to grade "A") to 1 (corresponding to grade "D or lower") and I create a variable which is equal to the mean of the three test scores and takes values between 1 and 4 .

As an indicator of child health, I include a dummy variable capturing who has poor physical health condition and any learning or physical disabilities. Additionally, I consider two indicators for obesity and underweight based on the Body Mass Index (BMI) cut-off points set by the World Health Organization (WHO) and Centers for Disease Control and Prevention. I distinguish between teenagers and adults over 20 years old and define as obese an individual in his twenties with a BMI higher than 30, or a teenager who has a BMI equal to or greater than the 95th percentile of the BMI distribution among children of the same sex and age. I adopt an analogous method to define those being underweight and I consider as underweight an adolescent with a BMI less than 18.5 or a teenager with a BMI value less than the 5th percentile. The BMI is based on self-reported values of height and weight of respondents in Wave I.

A measure of personality attractiveness was obtained using the interviewer's rating of personality attractiveness. ${ }^{14}$ The interviewer gives a score that goes from 1 ("very unattractive") to 5 ("very attractive").

\footnotetext{
${ }^{14}$ See Appendix A1 for the wording of this question to interviewer
} 


\section{Parenting style}

Some previous studies prove that the family engagement and the presence of communicative parents delay adolescent sexual experience (Inazu and Fox, 1980; Zelnick et al., 1981). I use different indicators for parenting style in order to capture various dimensions of the child-parent relationship as suggested by Ornelas et al. (2007). For all the indicators used, the Chronbach's alphas pass the common rule of thumb and are in line or higher than the alpha coefficients computed for analogous indexes (Ornelas et al., 2007).

I include a measure of parental engagement based on the time that the mother and father spend with their children, talking about personal problems, or simply telling each other what they have done during the day. For instance, children were asked if they go to shop with their parents, if they play sports together and if they talk about things the children do at school. The indicator is the sum of 11 items, taking values from 1 to $11 .{ }^{15}$

The child's perception of the level of cohesion in the household is measured through the sum of three items: how much he/she feels understood, how much attention the family pays him/her, and how often they have fun together. The scale goes from 3 to 15, where 15 indicate the highest level of family cohesion. ${ }^{16}$

Further, a seven-item measure of parental monitoring has been introduced to assess the presence of close monitoring and supervision by parents. These items include the freedom let to the child choose his/her bedtime, curfew times during the weekend, the people he/she associates with, what to wear, which television programmes and how often to watch and what to eat. The adolescent answers these questions with either yes (corresponding to value 1 ) or no (corresponding to value 0). Summing up the seven items, I obtain a variable taking values from 0 (very close monitoring) to 7 (no monitoring at all). ${ }^{17}$

Finally, I define two variables to measure the intensity and the quality of parent-child communication. It has been proven that communication on specific sexual related issues help him/her to develop responsible sexual behaviour. Communication is the means of

\footnotetext{
${ }^{15}$ The alpha reliability coefficient for this variable pass the common rule of thumb and it is higher (0.73) than the alpha coefficient for analogous indexes (Ornelas et al., 2007).

${ }^{16}$ The reliability of this variable is 0.79 in line with what was found by Ornelas et al. (2007).

${ }^{17}$ The alpha reliability coefficient is 0.64 which is in line with the 0.61 alpha found by Ornelas et al.(2007).
} 
transmitting values and norms which could affect later decisions. I define two variables to indicate to what extent parent and child talk about sexual issues and the parent's ability/attitude to talk about what in some cases is considered an embarrassing topic.

The first variable is a seven-item measure including information on how often the parent and child talk about having sexual intercourse, birth control methods, the negative or bad things that would happen in case of unwanted pregnancy, the dangers of getting a STD, the negative or bad impact of having sex, on the child's social life and the moral issues of not having sexual intercourse. ${ }^{18}$ The variable obtained summing together these questions has a range from 7 to 28 .

The second variable is an indicator of the parent's ability to talk about sex and birth control and it is obtained summing up two measures: to what extent the parent would be embarrassed to talk about it and how difficult it would be for him/her. Both questions come from the child questionnaire. The variable obtained ranges from 2 to 10 with 10 corresponding to the easiest communication on this topic. ${ }^{19}$

Another source of values and norms is religion. Some researchers have suggested that religious involvement is associated with the delay of sexual intercourse and decreases the number of partners (Billy et al., 1994; Day, 1992; Thornton and Camburn, 1987). I consider the child's religiosity measured by self-reported attendance of religious and importance given to religion (henceforth called religion salience). The first one takes value 0,1 or 2 if in the past 12 months the child has never, monthly or weekly attended a religious service, respectively. The second one takes value 0,1 or 2 if the child reports that the religion is respectively not important, fairly important or very important. ${ }^{20}$

\footnotetext{
${ }^{18}$ The responses fall under 5 categories: "not at all", "somewhat", "a moderate amount", "a great deal", the last one corresponding to the highest value. The alpha reliability coefficient is 0.90 .

${ }^{19}$ The alpha reliability coefficient for this indicator is equal to 0.78 .

${ }^{20}$ See Appendix A1 for more details about the religious services attendance and religion salience variables definition.
} 


\section{Econometric method}

The main objective of this chapter is to estimate the effect of self-esteem on the five sexual outcomes as defined in the previous section. Each of these outcomes $Y_{i}$ is a function of a polynomial expression of order 3 in self-esteem and a vector $\mathbf{X}_{i}$ of exogenous regressors:

$$
Y_{i}=\alpha_{0}+\alpha_{1} S_{i}+\alpha_{2} S_{i}^{2}+\alpha_{3} S_{i}^{3}+\boldsymbol{\beta} \mathbf{X}_{i}+u_{i}
$$

The non linearity of self-esteem can be theoretically explained by the discordant effect of self-esteem on an adolescent's sexual outcomes depending on the level of self-esteem achieved.

In attempting to estimate the causal effect of self-esteem on adolescent sexual behaviour, ordinary linear regression might produce biased and inconsistent estimates because selfesteem might be endogenous. The endogeneity problem arises if self-esteem is found to be correlated with the error term $u_{i}$. Such correlation occurs either because of relevant explanatory variables omitted in the model or for the presence of reverse causality between the sexual outcome observed and self-esteem. ${ }^{21}$ Concerning the first issue, there might be omitted (time-constant) preferences or family background characteristics which affect both self-esteem and adolescent sexual behaviour. For example, it has been found that children of teen mothers are at higher risk of becoming teen parents themselves than children born to older moms (Maynard, 1996).

Further previous studies on adolescent sexual behaviour suggest that self-esteem might be either the cause or the effect of various risky sexual behaviours, such as early sexual initiation or unprotected sexual intercourses. The endogenity bias due to the reverse causality problem is overcome thanks to longitudinal data which allow measuring selfesteem before sexual initiation. The other explanatory variables are either time constant or measured at the same time as self-esteem.

In this chapter an instrumental variable approach (IV) is used to explicitly address the endogeneity of self-esteem due to unobservables (Bowden and Turkington, 1984; Greene, 2000). ${ }^{22}$ The IV strategy consists of finding an exogenous source of random variation in

\footnotetext{
${ }^{21}$ See Wooldridge (2002), Ruud (2000) for a discussion on the different sources of endogeneity.

${ }^{22}$ The endogeneity of self-esteem is tested using the Durbin-Wu-Hausman test in the case of continuous
} 
self-esteem. This exogenous variable is known as instrument and has to be correlated with self-esteem but otherwise unrelated to the outcome of interest. The ideal instrumental variables predict self-esteem and have an impact on sexual outcomes only through selfesteem.

The instrumental variable approach jointly models the outcome $Y$ and the endogenous variables, $S, S^{2}$ and $S^{3}$ in the following way:

$$
\begin{aligned}
Y_{i} & =\alpha_{0}+\alpha_{1} S_{i}+\alpha_{2} S_{i}^{2}+\alpha_{3} S_{i}^{3}+\boldsymbol{\beta} \mathbf{X}_{i}+u_{i} \\
S_{i} & =\gamma_{1}+\boldsymbol{\delta}_{1} \mathbf{Z}_{i}+\boldsymbol{\rho}_{1} \mathbf{X}_{i}+v_{i 1} \\
S_{i}^{2} & =\gamma_{2}+\boldsymbol{\delta}_{2} \mathbf{Z}_{i}+\boldsymbol{\rho}_{2} \mathbf{X}_{i}+v_{i 2} \\
S_{i}^{3} & =\gamma_{3}+\boldsymbol{\delta}_{3} \mathbf{Z}_{i}+\boldsymbol{\rho}_{3} \mathbf{X}_{i}+v_{i 3}
\end{aligned}
$$

where $\mathbf{Z}$ is a set of instrumental variables such that $E\left(\mathbf{Z}_{i}, u_{i}\right)=0, E\left(\mathbf{Z}_{i}, S_{i}\right) \neq 0$ and the error terms $u_{i}, v_{i 1}, v_{i 2}$ and $v_{i 3}$ are allowed to be correlated.

In this application the endogenous variable $S$ is continuous and I treat the outcome variables either as continuous or binary. ${ }^{23}$ In the case of continuous outcome $Y$ is the actual outcome and I estimate the model using a two-stage least (2SLS) squares estimation. ${ }^{24}$

In the case of a binary outcome $d, Y$ is the unobserved latent variable belonging to the real number space which takes positive values if $d=1$ and strictly negative values otherwise. In this case, I estimate a probit model with endogenous regressors using maximum likelihood estimator (Wooldridge, 2002).

The condition $E\left(\mathbf{Z}_{i}, u_{i}\right)=0$ is usually called the exogeneity condition and imposes the mean independence of the instruments with respect to $u_{i}$. If an instrument is not exogenous (or invalid), the IV estimator is inconsistent given that the instruments are not able to

dependent variable. It tests whether the IV estimation provides coefficients that are significantly different than those provided by OLS estimation. If the null hypothesis (no systematic difference between IV and OLS estimates) is rejected (and the instruments used are valid) then the IV estimation provides unbiased results. Similarly, in case of binary model estimated by maximum likelihood, a Wald test is used to test whether the correlations between the error term in the main equation (1) and the ones in equations (2)-(4) are zeros (Wooldridge,2002). If the null hypothesis is rejected then OLS provides unbiased results.

${ }^{23}$ For simplicity, the count variables "number of sexual partners" and "number of STDs" are treated as continuous.

${ }^{24}$ Since equations (2)-(4) have the same set of regressors, the OLS estimation of the three equations estimated separately is identical to the feasible generalized least square of the system of equation. 
localize the exogenous variation in the endogenous regressor. The condition $E\left(\mathbf{Z}_{i}, S_{i}\right) \neq 0$ is usually called the relevance condition and requires the endogenous regressor and the instruments to be sufficiently correlated.

The validity of instrumental variable models depends on the ability to identify at least as many exogenous and strong instruments as endogenous variables (Wooldridge, 2002). An instrument is a strong instrument if it is a relevant explanatory variable in the self-esteem equation. The use of invalid or weak instruments lead to larger biases than in the case of OLS estimation (Stock et al, 2002; Hahn and Hausman, 2003).

The exogeneity condition can be tested using an overidentification test as proposed by Sargan (1958). ${ }^{25}$ The relevance condition can be tested in several ways, but the most common test is the first stage $F$-statistic developed by Stock and his colleagues (Stock and Staiger, 1997; Stock et al., 2002; Stock and Yogo, 2002). The F-statistic tests the hypothesis that the coefficients on the instruments in the first stage equations (equations 2-4) are significantly different from 0. Stock and Yogo (2002) suggest an F-statistics higher than 10 as an acceptable threshold to consider the instrument used, relevant. ${ }^{26}$

\section{The choice of instruments}

In social psychology, social comparison and reflected appraisal process, i.e. how we imagine other people see us, are considered fundamental in the development of self-esteem. The research for relevant instruments is based on the idea that social interaction has often been hypothesised as an important component of the child development and subsequently of his/her emotional health. It is widely agreed that during childhood family and school are the two main channels of socialization. Children compare themselves with the peers with whom they spend most of the time with, that is, their brothers, sisters and their schoolmates.

\footnotetext{
${ }^{25}$ In the case of probit models with endogenous regressors an overidentification test is not available for maximum likelihood estimation. Therefore, I estimate these models using the two steps estimation procedure suggested by Amemiya-Lee-Newey (Amemiya, 1978; Newey, 1987; Lee, 1992) and test for overidentification using the Sargan test.

${ }^{26}$ The bias which rises in case of weak instruments is inversely related to the $F$-statistic of the regression of the endogenous explanatory variable on the instruments (Hahn and Hausman, 2003). Since there is no test for weak instrument for endogenous probit model, I run the same specification using a 2SLS model to check that the instrument used is not weak.
} 
For the present analysis I restricted the search of relevant instruments to comparisons within the schoolmates' sample. This choice is due to limited number of siblings' pairs and the presence of numerous missing data that made impossible any kind of robust analysis using the siblings' sample.

I consider the differences in personality attractiveness between the adolescent and his/her schoolmates. More specifically I consider a dummy variable that takes value 1 if the child is more attractive than the average of his/her schoolmates, and 0 otherwise. Attractiveness is a measure of the interviewer's assessment of the respondent's personality attractiveness (Rosenberg et al., 1989). Having an unattractive personality may be highly correlated with self-esteem and it may have a direct effect on sexual outcomes. I hypothesize that being relatively more attractive than schoolmates' average have an effect on sexual outcomes only through self-esteem's mediation at least once controlled for adolescent's attractiveness.

Furthermore, I use an additional instrument which is the child's concern with his/her subjective physical attractiveness. It is widely agreed that being overweight affects sexual outcomes both directly, considering that obese people can be judged less attractive by potential sexual partners, and indirectly, having a negative impact on self-esteem (Biro at el., 2006). I control for the direct impact including "being obese" (or underweight) in the set of explanatory variables. The indirect effect can be considered using a measure of what can be defined as "subjective obesity". What really matters in terms of effects on self-esteem is the "self-image at mirror" or in other words, how you see yourself. Note that the subjective idea about obesity is the result of "peer group judgments to stereotypes attached to fat, average, and thin body" (Lawson, 1980). So this condition captures indirectly an element of peer interaction.

To obtain a measure of subjective obesity I construct a dummy variable that takes value 1 if two conditions occurred: 1) the child answers the question "How do you think of yourself in terms of weight?" saying "slightly overweight" or "very overweight" and 2) he /she reports to be trying to lose weight or to stay the same weight. The first condition alone is not enough. It is necessary to attach a personal judgment of being obese or overweight. For this reason the second condition seems particularly important. One person could be 
aware of being overweight but it may not represent a problem at all and thus it may not affect self-esteem in anyway. It seems reasonable to think that if being/seeing oneself obese represents a problem, the adolescent answers affirmatively the question "Are you trying to lose weight, or stay the same weight".

Finally, I define an additional instrument looking at the child-parent relationship. A number of longitudinal studies have documented that children and adolescents who enjoy emotionally close relations with their parents report better psychological health in adulthood (Bachman, 1978; Block, 1971; Snarey, 1993; Wallerstein, 1985; Roberts and Bengtson, 1996) and develop a greater self-esteem than other children (Barber and Rollins, 1990; McLeod and Shanahan, 1993). The argument here follows the classic symbolic "interactionist view of self-concepts as a social product and as reflexive phenomenon" (Mead, 1934; Blumer, 1969). Self-image is shaped by reflected appraisal; the appraisal from parents represents an important factor in how children and adolescents evaluate themselves.

I define a five-item measure of mother's support to assess the quality of the child-mother relation and the presence of warm and supportive parenting. These items measured how often the mother is warm and loving toward the child, the degree to which the mother encourages him to be independent or talks to him to make him understand why something is wrong; the last two items concern the child's satisfaction about his/her relationship with his/her mother and about the way they communicate. Each item is measured on a 5 -points scale. I sum them together and a high score indicates high maternal support. ${ }^{27}$

Using this indicator I identify those adolescents who are exceptionally supported and loved by their mothers, defining a dummy variable equal to one if the indicator for mother's support is higher than the average and 0 otherwise. Mother's support results to be highly correlated with adolescent's self-esteem and do not have any direct effect on sexual outcomes. $^{28}$

Finally, to strengthen the validity of my instruments, I control for a wide set of variables that may possibly be correlated with both self-esteem and sexual outcomes.

\footnotetext{
${ }^{27}$ The alpha reliability coefficient for this variable is 0.96 .

${ }^{28}$ Whitbeck et al.(1993) argue that the effects of parenting on adolescent sexuality are largely indirect through their influence on children's psychological well being.
} 


\section{Results}

Descriptive analysis showed that after controlling for socio-economic background, family and child characteristics, sexual outcomes of girls and boys and whites and blacks are still different. For this reason, I present the results separately by gender and ethnicity. ${ }^{29}$

At the bottom of each table (Table 5-9) I report either the Durbin-Wu-Hausman or the Wald test for self-esteem exogeneity and various diagnostic tests for weak instruments and over identification problems. ${ }^{30}$ Where self-esteem results to be exogenous I report either the OLS or probit estimates, otherwise the IV estimates are reported. In this last case, at the bottom of each table I report the instruments used in the estimates. Finally, I test the null hypothesis that the polynomial expression of order 3 in self-esteem is not statically different from zero. If the hypothesis cannot be rejected I repeat the same test for the polynomial expression of order 2. If in both the cases the null hypothesises are accepted, I estimate a linear model in self-esteem.

\section{Age of sexual debut}

In Table 5, I report the results for the age of sexual debut. I consider separately boys and girls, and the four possible combinations of gender (boys and girls) and ethnicity (black and white). ${ }^{31}$ In all models self-esteem is endogenous and needs to be instrumented.

There is strong evidence of the importance of self-esteem for some of the sub-samples considered. Significant differences emerged across ethnic groups and gender. According to the results reported in the first column of Table 5, self-esteem reduces early sexual intercourses among girls. However, as is clearly visible from the curve reported in panel A of Figure 1, this is the case for about 41 percent of the girls, those in the very bottom of the self-esteem distribution (1st percentile) and those with a self-esteem higher than the median value (from 60th percentile and beyond). ${ }^{32}$ Conversely, for self-esteem values

\footnotetext{
${ }^{29}$ Due to the relatively small sample size of black adolescents, some caution is recommended in interpreting the results found for blacks.

${ }^{30}$ Complete results of instrumental variable estimation are fully reported in the Appendix, Table A2-A6.

${ }^{31}$ Full results are presented in Table A2 in Appendix.

${ }^{32}$ The curve reported in Figure 1 as the other figures reported in this section are based on predictions computed using the estimated coefficients holding all control variables at their mean values. For example, the curve reported in panel A of Figure 1 shows the predicted age of sexual debut for an "average" girl.
} 
higher than 1st percentile and lower than the 60th percentile the curve becomes convex. It means that an increase in self-esteem decreases the age of sexual debut.

In the second and third column of Table 5, I report results obtained estimating separately a model for whites and blacks girls. Self-esteem turns out to be relevant just for white girls. This is similar to what was found when white and black girls were considered together. The self-esteem has a delaying effect for those adolescents with the lowest level of self-esteem and for 36 percent of white girls on the top of the self-esteem distribution (see Figure 1, Panel B). ${ }^{33}$ Again, for intermediate level of self-esteem (or in other words in about 63 percent of the cases) an increase of self-esteem contributes to earlier sexual initiation.

Within boys, self-esteem has no effects on the age of the first sexual intercourse as reported in the last three columns of Table 5. The estimated coefficient for black boys turn out to be negative even though it is not statistically different from zero. ${ }^{34}$ This indicates that for black boys an increase of self-esteem, if any, has an anticipating effect on their sexual debut.

\section{Number of sexual partners}

Most of the previous empirical works found that high self-esteem males and females have a significantly greater number of sexual partners than low self-esteem adolescents. Walsh (1991) argues that "any kind of behaviour that carries with it the risk of rejection requires a certain level of self-confidence that accompanies higher self-esteem". Thus, the number of sexual partners is expected to be higher for children with self-esteem over a "certain threshold" and particularly among males "who generally initiate any sexual activity" (Walsh, 1991).

Results reported in Table 6 confirm previous findings only for black boys. ${ }^{35}$ Self-esteem is a strong predictor of the number of sexual partners among girls, white girls and black boys. It acts as a protective factor for girls (and white girls in particular) while it has the

\footnotetext{
${ }^{33}$ The Panel B of Figure 1 shows the predicted age of sexual debut for an "average" white girl, i.e. computed using the estimated coefficients and holding all control variables at their mean values.

${ }^{34}$ Note that the polynomial terms of self-esteem are jointly insignificant and for these reason they are dropped.

${ }^{35}$ Full results are presented in Table A3 in Appendix.
} 
opposite effects for black boys.

In more details, an increase of self-esteem reduces the number of girls' sexual partners in general (first column, Table 6) and, as displayed in Figure 2, it has the same effects on 65 percent of white girls' subgroup (second column, Table 6) ${ }^{36}$ Conversely, for those white girls in the top 35th percentile of self-esteem distribution, the effect of self-esteem turns out to be positive. However, any potential risk enhancing effects of self-esteem for this group is very low. In fact, in correspondence of the 65th percentile, the curve becomes almost flat as the low value of the squared self-esteem term's coefficient suggests. It means that on average self-esteem still has a protective effect of reducing girls' sexual promiscuity.

Conversely, the number of sexual partners is an increasing function of self-esteem for black boys (last column, Table 6). The coefficient for self-esteem is positive (0.498) and the effect is, in absolute value, stronger than the average effect of self-esteem for girls (-0.228). Notably, self-esteem is positively correlated to the number of sexual partners even considering black and white boys together, but in this case its coefficient is not statistically different from zero (fourth column, Table 6). These findings are in line with what was reported above on the effect of self-esteem on the age of sexual debuts. Also in this case, self-esteem has a protective effect for part of the girls but not for boys.

\section{Probability of being diagnosed with STDs and number of STDs diagnosed in} the past year

Descriptive statistics reported in Table 2 shows that 15 percent of females have been diagnosed with at least one STDs in the last 12 months against 4 percent of males. In Table 7 (Panel A) I report the estimation results for the probit model for being diagnosed with at least one STD in the past 12 months. ${ }^{37}$ The Wald test cannot reject the null hypothesis of the exogeneity of self-esteem, meaning there is no sufficient evidence to consider self-esteem as an endogenous variable in the analysis. In Table 7 (Panel B) the model for the number of STDs diagnosed in the past 12 months is estimated using IV

\footnotetext{
${ }^{36}$ Figure 2 shows the predicted number of sexual partners for a white girl holding all control variables at their mean values.

${ }^{37}$ Full results are presented in Table A4 (Panel A) in Appendix.
} 
method for those subgroups of individuals for whom the Durbin-Wu-Hausman test rejects the null hypothesis of exogeneity (boys and girls), and using OLS otherwise (white and black boys and girls). ${ }^{38}$

In none of the models estimated (and regardless of the methods used) self-esteem has a significant effect on the likelihood to be diagnosed with at least one STDs in the past year and on the incidence of STDs diagnosed. ${ }^{39}$

\section{Use of condom: risk of contracting STDs}

In Table 8 I report the estimation results for the probit model for contraceptive use. ${ }^{40}$ The dependent variable takes value 1 if in none or only in some sexual intercourses in the past year he/she and his/her partner used condom and 0 if on most or all occasions they used it. In all models, except the one estimated for black girls (third column, Table 8), the Wald test confirms that self-esteem is exogenous suggesting that probit estimates might be consistent and more efficient.

Looking at results for girls (first and third column, Table 8), the likelihood of never (or just occasionally) using a condom is a decreasing function of self-esteem. That means that an increase of self-esteem among girls (and especially among black girls) decreases the probability of never or only occasionally using condoms. This is more relevant considering that among black girls the probability of contracting a STD is double than that for white girls (16 percent and 8 percent, respectively).

Once again, self-esteem has the opposite effects on boys acting as a risk enhancing factor (fourth column, Table 8). However, this is the case just for 20 percent of boys (Figure 3). ${ }^{41}$ Looking at the curve reported in Figure 3, notice that just for those boys who have self-esteem lower than the 20th percentile, any additional increase of self-esteem increases the probability of never using a condom.

\footnotetext{
${ }^{38}$ Full results are presented in Table A4 (Panel B) in Appendix.

${ }^{39}$ The sample used for these two estimations is the same used for all the other analysis. I also estimated the same model excluding children who did not have any sexual intercourse in the previous 12 months and the results do not change.

${ }^{40}$ Full results are presented in Table A5 in Appendix.

${ }^{41}$ Figure 3 displays the predicted probability of never or just occasionally use condom for an "average" boy.
} 


\section{Occasional use of birth control methods: risk of unintended pregnancy}

Table 9 reports the estimation results for the probit model for the use of birth control methods. ${ }^{42}$ The dependent variable takes value 1 if they never or just occasionally use any kind of birth control method. This variable can be considered as a proxy of the risk of unintended pregnancy. ${ }^{43}$ Self-esteem is found to be endogenous for black girls and IV estimates are reported (third column, Table 9).

Similarly to what was found for the use of condoms, the most interesting results are again for girls. The negative self-esteem coefficient for black girls indicates that self-confident girls are more likely to have protected sexual intercourses. As before, considering that the occurrence of unintended pregnancy is higher for black girls this result seems to be particularly relevant for policy implications.

Finally, self-esteem does not seem to have significant effect on boys' decision to use (or make their partner use) any contraceptive methods.

\section{Conclusions}

The results of this study show that self-esteem plays a significant role in explaining adolescents' sexual behaviour and gender differences in the considered sexual outcomes.

Self-esteem turns out to be a strong protective factor especially for girls and within the white subgroups. Girls with higher self-esteem have been found to delay the first sexual intercourse, to have fewer sexual partners and to be more likely to use birth control methods and contraceptives than low self-confident girls. This last effect is particularly strong for black girls. This makes the finding even more interesting and relevant given that the incidence of teenage pregnancy and the probability of being infected with STDs is higher within this subgroup. Self-confident girls are more likely to have protected intercourses because they make their partners use condoms and/or they use birth control

\footnotetext{
${ }^{42}$ Full results are presented in Table A6 in Appendix.

${ }^{43}$ Note that 7 out of 8 of birth control methods (birth control pills, implant, depo provera, diaphragm, emergency contraception or the morning after pill, natural family planning, female sterilization, condom) proposed by the interviewer can be used only by females.
} 
methods more frequently. On the contrary, a low level of self-esteem raises the probability to never or only occasionally use condoms.

However, self-esteem might be a "double edged sword". In some cases a certain amount of self-esteem is required in order to make any marginal increase of self-esteem effective in protecting the adolescent against potentially risky behaviours. In other cases, a higher level of self-esteem contributes to enhance the probability of engaging in risky behaviours.

For example, self-esteem contributes to delay the sexual debut of those girls who are above the 60th percentile of the self-esteem distribution; otherwise it has the opposite effect. Conversely, self-esteem reduces sexual promiscuity for those girls who are below the 65th percentile of the self-esteem distribution, while it has the opposite effect for those with high self-esteem, i.e. those who are above the 35th percentile. However, in both cases the protective effect of self-esteem has been found to be stronger than the risk enhancing effect, which is in fact quite low.

Notwithstanding, in most of the cases self-esteem does not affect boys' behaviour. However, when it has an effect, it is opposite of what was found for girls. Self-esteem does not promote responsible sexual behaviour, especially among black boys who are more likely to have a higher number of sexual partners and unprotected sexual relations.

Further research may be done in the direction of studying self-esteem as a determinant of the female negotiating power within a couple, for example concerning the use of contraceptive methods. Furthermore, it might be interesting to introduce other indicators of psychological well-being or personality traits and investigate the role of expectations, aspiration and economic opportunities to explain adolescent sexual behaviour. 


\section{Tables and Figures}

Table 1 Gender and ethnic composition of the sample

Panel A

\begin{tabular}{|c|c|c|c|c|c|}
\hline \multirow[b]{3}{*}{ Variable } & \multicolumn{2}{|c|}{ Girls } & \multicolumn{2}{|c|}{ Boys } & \\
\hline & \multicolumn{2}{|c|}{$N(3,192)$} & \multicolumn{2}{|c|}{$N(2,543)$} & t test \\
\hline & Mean & Std. Dev. & Mean & Std. Dev. & p-value \\
\hline Age (wave1) & 14.27 & $(0.047)$ & 14.50 & (0.057) & $(0.001)$ \\
\hline Age (wave3) & 21.19 & $(0.048)$ & 21.45 & $(0.057)$ & $(0.001)$ \\
\hline White & 0.70 & $(0.015)$ & 0.77 & $(0.015)$ & $(0.001)$ \\
\hline \multicolumn{6}{|l|}{ Panel B } \\
\hline & \multicolumn{2}{|c|}{ White } & \multicolumn{2}{|c|}{ Black } & \\
\hline & \multicolumn{2}{|c|}{$N(4,085)$} & \multicolumn{2}{|c|}{$\mathrm{N}(1,598)$} & t test \\
\hline Variable & Mean & Std. Dev. & Mean & Std. Dev. & p-value \\
\hline Age (wave1) & 14.37 & $(0.046)$ & 14.36 & $(0.055)$ & $(0.882)$ \\
\hline Age (wave3) & 21.31 & $(0.047)$ & 21.30 & $(0.057)$ & (0.899) \\
\hline Female & 0.54 & $(0.018)$ & 0.62 & $(0.019)$ & $(0.001)$ \\
\hline
\end{tabular}

Note: Average values; standard deviation in parentheses. T-test for differences in mean ( $\mathrm{p}$-value reported in the last column) 
Table 2 Sexual outcomes by gender

Panel A: Sexual outcomes by gender

\begin{tabular}{|c|c|c|c|c|c|}
\hline \multirow[b]{3}{*}{ Sexual outcomes } & \multirow{2}{*}{\multicolumn{2}{|c|}{$\frac{\text { Girls }}{\mathbf{N}(3,192)}$}} & \multicolumn{2}{|c|}{ Boys } & \multirow{3}{*}{$\begin{array}{l}\text { t test } \\
\text { p-value }\end{array}$} \\
\hline & & & \multicolumn{2}{|c|}{$N(2,543)$} & \\
\hline & Mean & Std. Dev. & Mean & Std. Dev. & \\
\hline Average age sexual debut & 16.86 & $(0.042)$ & 17.11 & $(0.051)$ & $(0.343)$ \\
\hline Having sex before age $15,(\%)$ & 0.23 & $(0.009)$ & 0.19 & $(0.010)$ & $(0.001)$ \\
\hline Having sex before age $18,(\%)$ & 0.83 & $(0.008)$ & 0.81 & $(0.009)$ & $(0.019)$ \\
\hline \multicolumn{6}{|l|}{ Number of sexual partners } \\
\hline By the age of 18 & 3.50 & $(0.668)$ & 3.89 & $(0.923)$ & $(0.735)$ \\
\hline By the age of 22 & 4.95 & $(0.139)$ & 5.85 & $(0.189)$ & $(0.000)$ \\
\hline \multicolumn{6}{|c|}{$\begin{array}{l}\text { Use of Contraceptives: never or just } \\
\text { occasionally used (in the past } 12 \text { months) }\end{array}$} \\
\hline Condom & 0.62 & $(0.011)$ & 0.52 & $(0.013)$ & $(0.000)$ \\
\hline Any birth control methods & 0.30 & $(0.010)$ & 0.28 & $(0.011)$ & $(0.779)$ \\
\hline \multicolumn{6}{|c|}{ Diagnosed STDs (in the past 12 months) } \\
\hline Diagnosed with at least one STD & 0.15 & $(0.007)$ & 0.04 & $(0.005)$ & $(0.000)$ \\
\hline Number of STD diagnosed & 0.19 & $(0.011)$ & 0.09 & $(0.018)$ & $(0.000)$ \\
\hline \multicolumn{6}{|c|}{ Panel B: Sexual outcomes by ethnic group } \\
\hline & \multicolumn{2}{|c|}{ White } & \multicolumn{2}{|c|}{ Black } & \\
\hline & \multicolumn{2}{|c|}{$N(4,085)$} & \multicolumn{2}{|c|}{$N(\mathbf{1 , 5 9 8})$} & t test \\
\hline Sexual outcomes & Mean & Std. Dev. & Mean & Std. Dev. & $\mathrm{p}$-value \\
\hline Age sexual debut & 17.09 & $(0.040)$ & 16.66 & $(0.052)$ & $(0.000)$ \\
\hline Having sex before age $15,(\%)$ & 0.20 & $(0.008)$ & 0.24 & $(0.013)$ & $(0.013)$ \\
\hline Having sex before age $18,(\%)$ & 0.80 & $(0.008)$ & 0.88 & $(0.009)$ & $(0.000)$ \\
\hline \multicolumn{6}{|l|}{ Number of sexual partners } \\
\hline By the age of 18 & 3.70 & $(0.694)$ & 3.30 & $(0.803)$ & $(0.706)$ \\
\hline By the age of 22 & 5.13 & $(0.131)$ & 5.83 & $(0.219)$ & $(0.006)$ \\
\hline \multicolumn{6}{|c|}{$\begin{array}{l}\text { Use of Contraceptives: never or just } \\
\text { occasionally used (in the past } 12 \text { months) }\end{array}$} \\
\hline Condom & 0.61 & $(0.010)$ & 0.48 & $(0.015)$ & $(0.000)$ \\
\hline Any birth control methods & 0.26 & $(0.008)$ & 0.37 & $(0.015)$ & $(0.000)$ \\
\hline \multicolumn{6}{|c|}{ Diagnosed STDs (in the past 12 months) } \\
\hline Diagnosed with at least one STD & 0.08 & $(0.005)$ & 0.16 & $(0.011)$ & $(0.000)$ \\
\hline Number of STD diagnosed & 0.11 & $(0.009)$ & 0.26 & $(0.028)$ & $(0.000)$ \\
\hline
\end{tabular}

Note: Average values; standard deviation in parentheses. T-test for differences in mean (pvalue reported in the last column) 
Table 3 Self-esteem by gender and ethnic group

Panel A: self-esteem by gender

\begin{tabular}{cccccc}
\hline & \multicolumn{2}{c}{ Girls } & \multicolumn{2}{c}{ Boys } \\
\cline { 2 - 6 } Self-esteem measurements & \multicolumn{2}{c}{$\mathbf{N}(\mathbf{3 , 1 9 2})$} & \multicolumn{2}{c}{$\mathbf{N}(\mathbf{2 , 5 4 3})$} & \multicolumn{1}{c}{ t test } \\
\hline Self esteem (SE) & Mean & Std. Dev. & Mean & Std. Dev. & p-value \\
0-25th quintiles & 18.42 & $(0.082)$ & 19.61 & $(0.073)$ & $(0.000)$ \\
25-50th quintiles & 0.36 & $(0.010)$ & 0.23 & $(0.010)$ & $(0.000)$ \\
50-75th quintiles & 0.26 & $(0.009)$ & 0.26 & $(0.010)$ & $(0.928)$ \\
75-100th quintiles & 0.22 & $(0.009)$ & 0.26 & $(0.010)$ & $(0.000)$ \\
& 0.17 & $(0.008)$ & 0.24 & $(0.010)$ & $(0.000)$ \\
\hline
\end{tabular}

Panel B: self-esteem by ethnic group

\begin{tabular}{cccccc}
\hline & \multicolumn{2}{c}{ White } & \multicolumn{2}{c}{ Black } & \\
\cline { 2 - 6 } Self-esteem measurements & \multicolumn{2}{c}{$\mathbf{N}(\mathbf{4 , 0 8 5})$} & \multicolumn{2}{c}{$\mathbf{N}(\mathbf{1 , 5 9 8})$} & t test \\
Self esteem (SE) & Mean & Std. Dev. & Mean & Std. Dev. & p-value \\
0-25th quintiles & 18.71 & $(0.069)$ & 19.57 & $(0.102)$ & $(0.000)$ \\
25-50th quintiles & 0.33 & $(0.009)$ & 0.24 & $(0.013)$ & $(0.000)$ \\
50-75th quintiles & 0.26 & $(0.008)$ & 0.25 & $(0.013)$ & $(0.400)$ \\
75-100th quintiles & 0.22 & $(0.008)$ & 0.28 & $(0.013)$ & $(0.000)$ \\
& 0.18 & $(0.007)$ & 0.24 & $(0.013)$ & $(0.000)$ \\
\hline
\end{tabular}

Note: Average values; standard deviation in parentheses. T-test for differences in mean (pvalue reported in the last column). Quantiles refer to the whole sample of boys and girls and Whites and Black. 
Table 4 Control variables: by gender (Panel A)

Panel A: explanatory variables by gender

\begin{tabular}{|c|c|c|c|c|c|}
\hline \multirow[b]{3}{*}{ Explanatory variables } & \multirow{2}{*}{\multicolumn{2}{|c|}{$\begin{array}{c}\text { Girls } \\
\mathrm{N}(3,192)\end{array}$}} & \multicolumn{2}{|c|}{ Boys } & \multirow{3}{*}{$\begin{array}{l}\mathbf{t} \text { test } \\
\mathrm{p} \text {-value }\end{array}$} \\
\hline & & & $\overline{\mathbf{N}}$ & 543) & \\
\hline & Mean & Std. Dev. & Mean & Std. Dev. & \\
\hline \multicolumn{6}{|l|}{$\begin{array}{l}\text { Family socio-economic } \\
\text { characteristics }\end{array}$} \\
\hline Income & 48.54 & $(1.435)$ & 50.28 & $(1.558)$ & $(0.411)$ \\
\hline Household's size & 4.55 & $(0.033)$ & 4.42 & $(0.034)$ & $(0.005)$ \\
\hline Parent full-time job & 0.59 & $(0.011)$ & 0.60 & $(0.012)$ & $(0.484)$ \\
\hline Economic stressor & 0.82 & $(0.009)$ & 0.85 & $(0.009)$ & $(0.019)$ \\
\hline \multicolumn{6}{|l|}{ Parents'education } \\
\hline Less than high school & 0.07 & $(0.006)$ & 0.05 & $(0.005)$ & $(0.000)$ \\
\hline High school/Some college & 0.55 & $(0.011)$ & 0.51 & $(0.013)$ & $(0.047)$ \\
\hline College graduate (or over) & 0.38 & $(0.011)$ & 0.44 & $(0.013)$ & $(0.000)$ \\
\hline \multicolumn{6}{|l|}{ Household composition } \\
\hline No residential parents & 0.04 & $(0.004)$ & 0.03 & $(0.004)$ & $(0.021)$ \\
\hline Single parent & 0.29 & $(0.010)$ & 0.27 & $(0.011)$ & $(0.118)$ \\
\hline Both residential parents & 0.67 & $(0.011)$ & 0.71 & $(0.011)$ & $(0.020)$ \\
\hline \multicolumn{6}{|l|}{ Parenting style } \\
\hline Family cohesion (3-15) & 11.23 & $(0.054)$ & 11.48 & $(0.060)$ & $(0.002)$ \\
\hline Parental monitoring $(0-7)$ & 5.02 & $(0.034)$ & 5.04 & $(0.037)$ & $(0.703)$ \\
\hline Family engagement (1-11) & 3.96 & $(0.037)$ & 3.60 & $(0.042)$ & $(0.000)$ \\
\hline $\begin{array}{l}\text { Communication about sex is } \\
(7-28)\end{array}$ & 18.21 & $(0.107)$ & 16.65 & $(0.128)$ & $(0.000)$ \\
\hline $\begin{array}{l}\text { Ability to talk about sex is } \\
\text { 10) }\end{array}$ & 8.28 & $(0.037)$ & 7.77 & $(0.046)$ & $(0.000)$ \\
\hline \multicolumn{6}{|l|}{$\begin{array}{l}\text { Child demographic } \\
\text { charactheristics }\end{array}$} \\
\hline Age & 21.19 & $(0.048)$ & 21.45 & $(0.057)$ & $(0.001)$ \\
\hline Ethnicity: Black & 0.30 & $(0.015)$ & 0.23 & $(0.015)$ & $(0.001)$ \\
\hline \multicolumn{6}{|l|}{ School attainment } \\
\hline Grade (1-4) & 2.92 & $(0.017)$ & 2.75 & $(0.020)$ & $(0.000)$ \\
\hline \multicolumn{6}{|l|}{ Health and attractiveness } \\
\hline Poor health* disability & 0.01 & $(0.002)$ & 0.01 & $(0.002)$ & $(0.966)$ \\
\hline Underweight & 0.06 & $(0.005)$ & 0.05 & $(0.005)$ & $(0.082)$ \\
\hline Obese & 0.04 & $(0.004)$ & 0.03 & $(0.004)$ & $(0.043)$ \\
\hline Attractive (2-10) & 7.42 & $(0.034)$ & 6.99 & $(0.035)$ & $(0.000)$ \\
\hline \multicolumn{6}{|l|}{ Religion attendance } \\
\hline Never & 0.09 & $(0.007)$ & 0.12 & $(0.008)$ & $(0.003)$ \\
\hline Once per month & 0.41 & $(0.011)$ & 0.42 & $(0.012)$ & $(0.556)$ \\
\hline Once per week or more & 0.50 & $(0.012)$ & 0.46 & $(0.012)$ & $(0.021)$ \\
\hline
\end{tabular}

Note: Average values; standard deviation in parentheses. T-test for differences in mean ( $\mathrm{p}$-value reported in the last column) 
Table 4 Control variables: by ethnic group (Panel B)

Panel B: explanatory variables by ethnic group

\begin{tabular}{|c|c|c|c|c|c|}
\hline \multirow[b]{3}{*}{ Explanatory variables } & \multirow{2}{*}{\multicolumn{2}{|c|}{$\begin{array}{c}\text { White } \\
\mathbf{N}(4,085)\end{array}$}} & \multicolumn{2}{|c|}{ Black } & \multirow{3}{*}{$\begin{array}{l}\text { t test } \\
\text { p-value }\end{array}$} \\
\hline & & & & ,598) & \\
\hline & Mean & Std. Dev. & Mean & Std. Dev. & \\
\hline \multirow{2}{*}{\multicolumn{6}{|c|}{$\begin{array}{l}\text { Family socio-economic } \\
\text { characteristics }\end{array}$}} \\
\hline & & & & & \\
\hline Income & 53.66 & $(1.336)$ & 36.20 & $(1.112)$ & $(0.000)$ \\
\hline Household's size & 4.41 & $(0.025)$ & 4.72 & $(0.055)$ & $(0.000)$ \\
\hline Parent full-time job & 0.57 & $(0.009)$ & 0.66 & $(0.015)$ & $(0.000)$ \\
\hline Economic stressor & 0.87 & $(0.007)$ & 0.74 & $(0.014)$ & $(0.000)$ \\
\hline \multicolumn{6}{|l|}{ Parents'education } \\
\hline Less than high school & 0.05 & $(0.004)$ & 0.09 & $(0.009)$ & $(0.000)$ \\
\hline High school/Some college & 0.55 & $(0.010)$ & 0.48 & $(0.017)$ & $(0.000)$ \\
\hline College graduate (or over) & 0.40 & $(0.010)$ & 0.43 & $(0.017)$ & $(0.066)$ \\
\hline \multicolumn{6}{|l|}{ Household composition } \\
\hline No residential parents & 0.02 & $(0.002)$ & 0.08 & $(0.008)$ & $(0.000)$ \\
\hline Single parent & 0.21 & $(0.008)$ & 0.45 & $(0.015)$ & $(0.000)$ \\
\hline Both residential parents & 0.77 & $(0.008)$ & 0.47 & $(0.015)$ & $(0.000)$ \\
\hline \multicolumn{6}{|l|}{ Parenting style } \\
\hline Family cohesion (3-15) & 11.30 & $(0.047)$ & 11.46 & $(0.076)$ & $(0.075)$ \\
\hline Parental monitoring (0-7) & 5.10 & $(0.029)$ & 4.84 & $(0.047)$ & $(0.000)$ \\
\hline Family engagement (1-11) & 3.79 & $(0.034)$ & 3.85 & $(0.054)$ & $(0.368)$ \\
\hline $\begin{array}{l}\text { Communication about sex } \mathrm{i} \\
(7-28)\end{array}$ & 16.96 & $(0.096)$ & 19.15 & $(0.153)$ & $(0.000)$ \\
\hline $\begin{array}{l}\text { Ability to talk about sex iss } \\
\text { 10) }\end{array}$ & 8.06 & $(0.034)$ & 8.05 & $(0.058)$ & $(0.937)$ \\
\hline \multicolumn{6}{|l|}{$\begin{array}{l}\text { Child demographic } \\
\text { charactheristics }\end{array}$} \\
\hline Age & 21.31 & $(0.047)$ & 21.30 & $(0.057)$ & $(0.899)$ \\
\hline Ethnicity: Black & 0.46 & $(0.018)$ & 0.38 & $(0.019)$ & $(0.001)$ \\
\hline \multicolumn{6}{|l|}{ School attainment } \\
\hline Grade (1-4) & 2.92 & $(0.015)$ & 2.64 & $(0.023)$ & $(0.000)$ \\
\hline \multicolumn{6}{|l|}{ Health and attractiveness } \\
\hline Poor health* disability & 0.01 & $(0.002)$ & 0.01 & $(0.003)$ & $(0.760)$ \\
\hline Underweight & 0.07 & $(0.005)$ & 0.03 & $(0.005)$ & $(0.000)$ \\
\hline Obese & 0.03 & $(0.003)$ & 0.07 & $(0.007)$ & $(0.000)$ \\
\hline Attractive (2-10) & 7.29 & $(0.030)$ & 7.07 & $(0.049)$ & $(0.000)$ \\
\hline \multicolumn{6}{|l|}{ Religion attendance } \\
\hline Never & 0.12 & $(0.006)$ & 0.06 & $(0.007)$ & $(0.000)$ \\
\hline Once per month & 0.44 & $(0.010)$ & 0.36 & $(0.015)$ & $(0.000)$ \\
\hline Once per week or more & 0.44 & $(0.010)$ & 0.58 & $(0.016)$ & $(0.000)$ \\
\hline
\end{tabular}

Note: Average values; standard deviation in parentheses. T-test for differences in mean ( $\mathrm{p}$-value reported in the last column) 
Table 5 Age of sexual debut

\section{Age of first sexual intercourse}

\begin{tabular}{|c|c|c|c|c|c|c|}
\hline & Girls & $\begin{array}{l}\text { Girls: } \\
\text { White }\end{array}$ & $\begin{array}{l}\text { Girls: } \\
\text { Black }\end{array}$ & Boys & $\begin{array}{l}\text { Boys: } \\
\text { White }\end{array}$ & $\begin{array}{l}\text { Boys: } \\
\text { Black }\end{array}$ \\
\hline Self esteem & $\begin{array}{c}3.239 * * \\
(1.463)\end{array}$ & $\begin{array}{c}2.917 * * \\
(1.366)\end{array}$ & $\begin{array}{c}0.082 \\
(0.055)\end{array}$ & $\begin{array}{c}0.047 \\
(0.054)\end{array}$ & $\begin{array}{c}0.041 \\
(0.066)\end{array}$ & $\begin{array}{l}-0.012 \\
(0.088)\end{array}$ \\
\hline Self esteem ${ }^{\wedge} 2$ & $\begin{array}{c}-0.346^{* *} \\
(0.173)\end{array}$ & $\begin{array}{c}-0.323 * * \\
(0.163)\end{array}$ & · & . & & $\cdot$ \\
\hline Self esteem ${ }^{\wedge} 3$ & $\begin{array}{l}0.009 * \\
(0.005)\end{array}$ & $\begin{array}{l}0.009 * \\
(0.005)\end{array}$ & . & . & . & . \\
\hline \multicolumn{7}{|l|}{ First stage: IVs } \\
\hline Mother's support & $\begin{array}{c}1.872 * * * \\
(0.134)\end{array}$ & $\begin{array}{c}1.548 * * * \\
(0.188)\end{array}$ & $\begin{array}{c}2.533 * * * \\
(0.288)\end{array}$ & $\begin{array}{c}1.593 * * * \\
(0.125)\end{array}$ & $\begin{array}{c}1.501 * * * \\
(0.178)\end{array}$ & $\begin{array}{c}2.112 * * * \\
(0.310)\end{array}$ \\
\hline Personality attractiveness & $\begin{array}{c}0.165 \\
(0.170)\end{array}$ & $\begin{array}{l}0.430^{*} \\
(0.239)\end{array}$ & $\begin{array}{c}0.016 \\
(0.373)\end{array}$ & $\begin{array}{c}0.245 \\
(0.162)\end{array}$ & $\begin{array}{c}0.130 \\
(0.225)\end{array}$ & $\begin{array}{c}0.773 * * \\
(0.389)\end{array}$ \\
\hline Subjective obesity & $\begin{array}{r}-1.197 * * * \\
(0.125) \\
\end{array}$ & $\begin{array}{c}-1.322 * * * \\
(0.174) \\
\end{array}$ & $\begin{array}{c}-1.028 * * * \\
(0.282)\end{array}$ & $=\begin{array}{c}-1.074 * * * \\
(0.143)\end{array}$ & $\begin{array}{c}-1.045^{* * *} * \\
(0.200) \\
\end{array}$ & $\begin{array}{c}-0.719 * \\
(0.419) \\
\end{array}$ \\
\hline F-test: self-esteem & 70.01 & 43.40 & 29.13 & 48.41 & 47.48 & 18.80 \\
\hline Sargan overid: $p$ value & . & 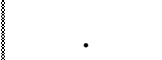 & 0.47 & 0.09 & 0.10 & 0.63 \\
\hline Durbin-Wu-Hausman & 0.01 & 0.09 & 0.00 & 0.05 & 0.04 & 0.05 \\
\hline Observations & 2000 & 1426 & 574 & 1656 & 1282 & 374 \\
\hline
\end{tabular}

Note: All control variables included (see list reported in Table 2.4). All models in the table have been estimated by instrumental variable estimation. Asterisks indicate significance at * $0.1 * * 0.05 * * * 0.01$ levels, respectively. The Sargan test is missing where there are no overidentifying restrictions to be tested (number of instruments is equal to the number of endogenous variables). 
Figure 1 Age of sexual debut

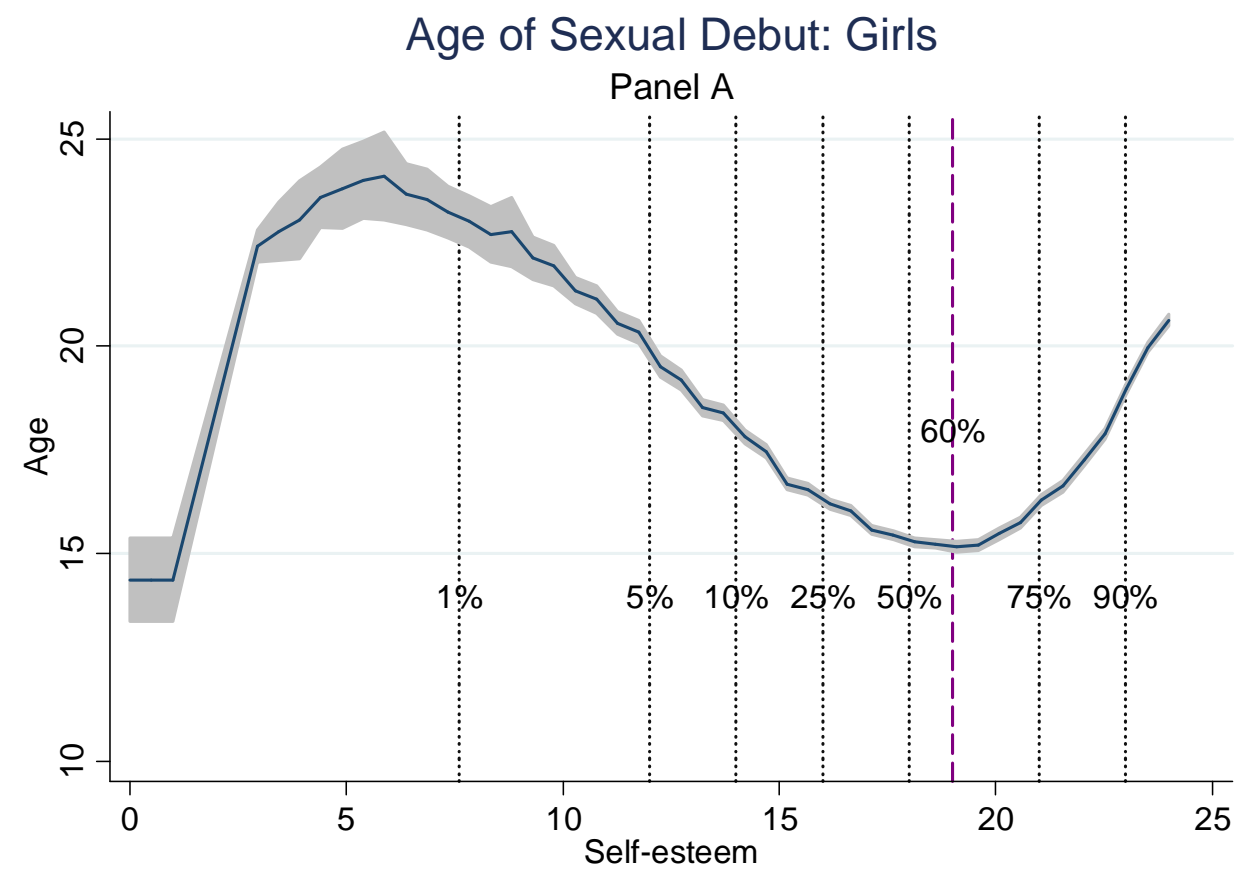

Age of Sexual Debut: Girls: White

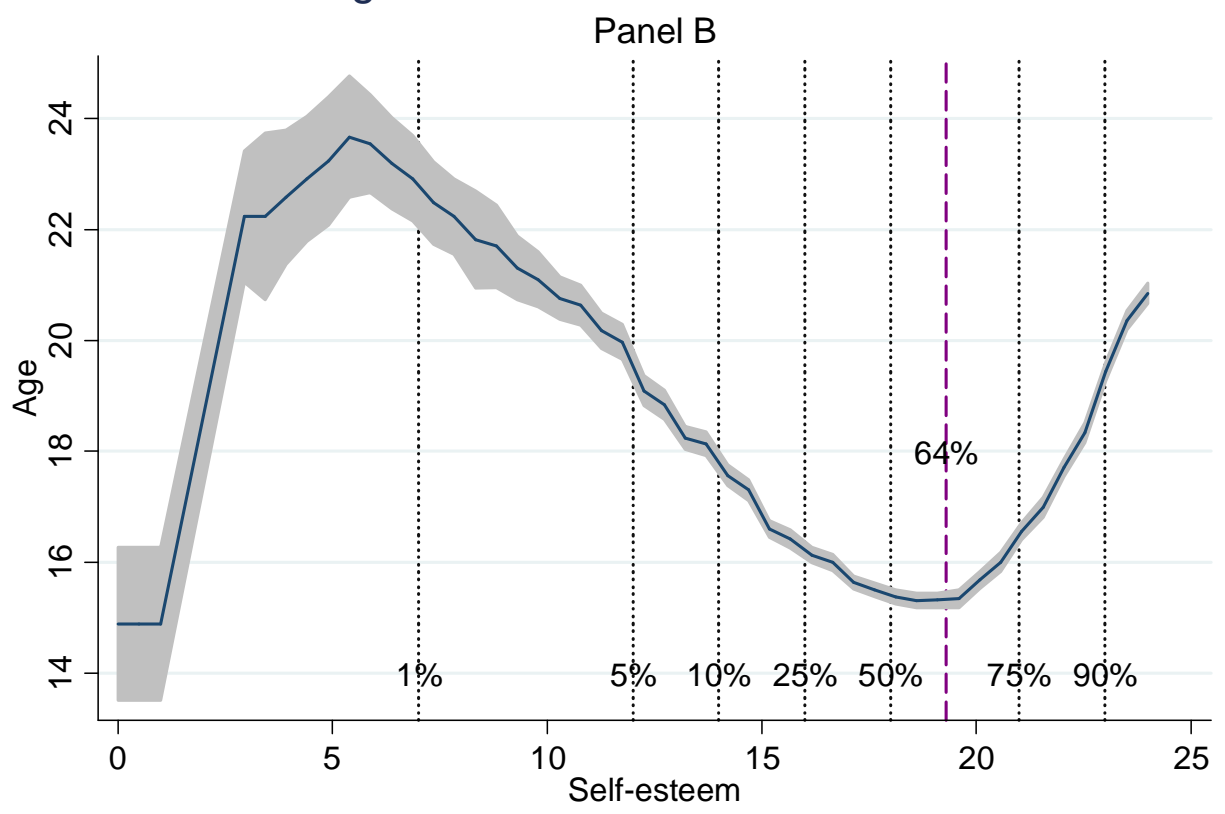

Note: The local polynomial smooth plot is based on a prediction computed using the estimated coefficients holding all control variables at their mean values ( $95 \%$ confidence interval reported). Vertical lines in correspondence of the self-esteem's values for the $1^{\text {st }}, 5^{\text {th }}, 10^{\text {th }}, 25^{\text {th }}$, $50^{\text {th }}, 75^{\text {th }}$ and $90^{\text {th }}$ (dashed lines) percentile of self-esteem's distribution for the sample considered in the estimation and of the $60^{\text {th }}$ and $64^{\text {th }}$ percentile of self-esteem at the upper inflection points (dotted line). 
Table 6 Number of sexual partners

\begin{tabular}{|c|c|c|c|c|c|c|}
\hline \multicolumn{7}{|c|}{ Number of sexual partners } \\
\hline & Girls & $\begin{array}{l}\text { Girls: } \\
\text { White }\end{array}$ & $\begin{array}{l}\text { Girls: } \\
\text { Black }\end{array}$ & Boys & $\begin{array}{l}\text { Boys: } \\
\text { White }\end{array}$ & $\begin{array}{l}\text { Boys: } \\
\text { Black }\end{array}$ \\
\hline Self esteem & $\begin{array}{c}-0.228 * * \\
(0.113)\end{array}$ & $-0.533 * * * *$ & $\begin{array}{l}-0.013 \\
(0.072)\end{array}$ & $\begin{array}{c}0.110 \\
(0.212)\end{array}$ & $\begin{array}{l}-0.037 \\
(0.064)\end{array}$ & $\begin{array}{c}0.498 * * * \\
(0.165)\end{array}$ \\
\hline Self esteem ${ }^{\wedge} 2$ & . & $\begin{array}{c}0.015^{* *} * \\
(0.006)\end{array}$ & . & . & . & . \\
\hline \multicolumn{7}{|l|}{ First stage: IVs } \\
\hline Mother's support & $\begin{array}{c}1.875^{* * *} \\
(0.157)\end{array}$ & . & . & $\begin{array}{c}1.639 * * * \\
(0.153)\end{array}$ & . & . \\
\hline Personality attractiveness & $\begin{array}{c}0.293 \\
(0.201)\end{array}$ & . & . & $\begin{array}{c}0.269 \\
(0.194)\end{array}$ & . & . \\
\hline Subjective obesity & $\begin{array}{r}-1.205^{* * *} \\
(0.148)\end{array}$ & . & . & $\begin{array}{c}-0.990 * * * * \\
(0.178)\end{array}$ & . & . \\
\hline F-test: self-esteem & 68.94 & . & . & 47.90 & . & . \\
\hline Sargan overid: $p$ value & 0.19 & . & . & 0.89 & . & . \\
\hline Durbin-Wu-Hausman & 0.06 & 0.74 & 0.26 & 0.07 & 0.31 & 0.29 \\
\hline Observations & 1984 & 1420 & 564 & 1641 & 1274 & 367 \\
\hline
\end{tabular}

Note: All control variables included. (see list reported in Table 2.4). Asterisks indicate significance at* $0.1 * * 0.05 * * * 0.01$ levels, respectively. The number of sexual partners for the sample of girls and boys (first and fourth columns) have been estimated by instrumental variable estimation; the remaining models by OLS. The Sargan test is missing where there are no over- identifying restrictions to be tested (number of instruments is equal to the number of endogenous variables). 
Figure 2 Number of sexual partners

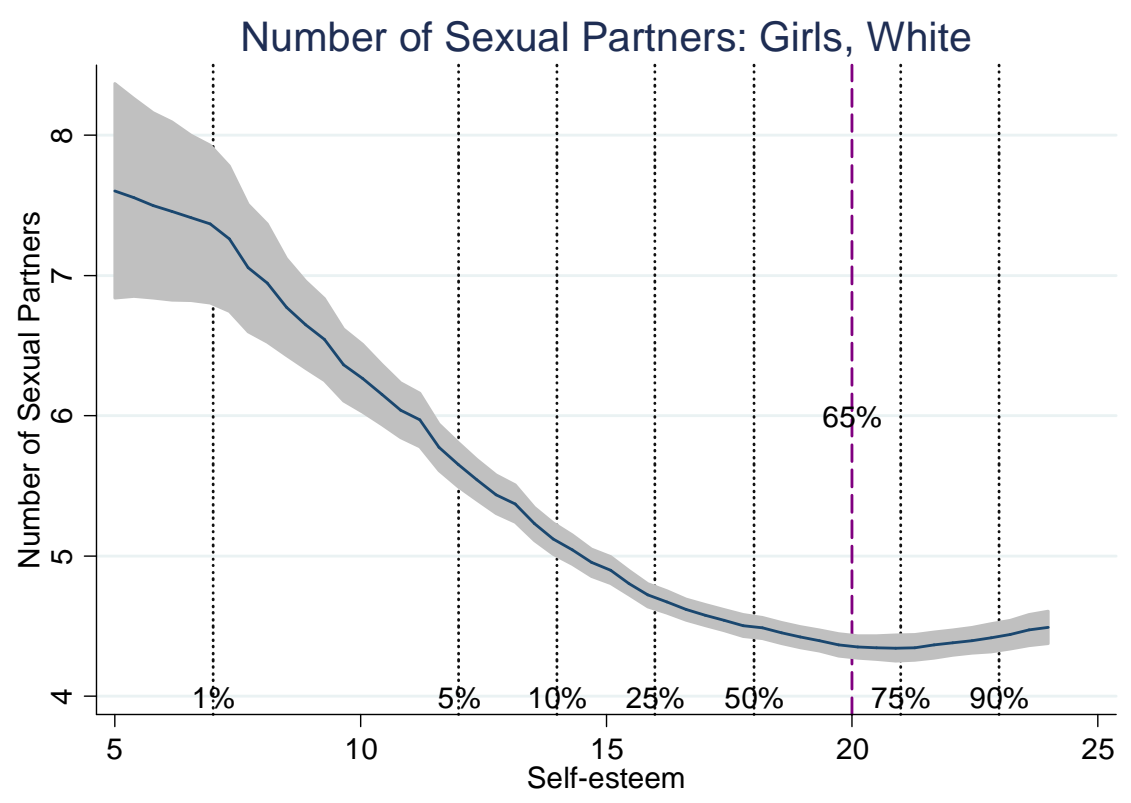

Note: The local polynomial smooth plot is based on a prediction computed using the estimated coefficients holding all control variables at their mean values $(95 \%$ confidence interval reported). Vertical lines in correspondence of the self-esteem's values for the $1^{\text {st }}, 5^{\text {th }}, 10^{\text {th }}, 25^{\text {th }}, 50^{\text {th }}, 75^{\text {th }}$ and $90^{\text {th }}$ (dashed lines) percentile of self-esteem's distribution for the sample considered in the estimation and of the $60^{\text {th }}$ and $64^{\text {th }}$ percentile of self-esteem at the upper inflection points (dotted line). 
Table 7 (Panel A) Probability of have been diagnosed with at least one STD in the past year

Probability of being diagnosed with at least one STD

\begin{tabular}{lc|c|c|c|c|c}
\hline & Girls & $\begin{array}{l}\text { Girls: } \\
\text { White }\end{array}$ & $\begin{array}{l}\text { Girls: } \\
\text { Black }\end{array}$ & Boys & $\begin{array}{l}\text { Boys: } \\
\text { White }\end{array}$ & $\begin{array}{l}\text { Boys: } \\
\text { Black }\end{array}$ \\
\hline \multirow{2}{*}{ Self esteem } & & & & & & \\
& -0.010 & -0.020 & 0.008 & 0.001 & -0.006 & 0.007 \\
& $(0.011)$ & $(0.014)$ & $(0.018)$ & $(0.021)$ & $(0.027)$ & $(0.038)$ \\
\hline Wald test (exogeneity) & 0.76 & 0.94 & 0.49 & 0.28 & 0.13 & 0.77 \\
Pseudo R-sq & 0.06 & 0.10 & 0.03 & 0.04 & 0.12 & 0.07 \\
\hline Observations & 2000 & 1426 & 568 & 1647 & 1275 & 354 \\
\hline
\end{tabular}

Note: All control variables included (see list reported in Table 2.4). All models in the table have been estimated by probit model. Marginal effects reported. Asterisks indicate significance at $* 0.1 * * 0.05 * * * 0.01$ levels, respectively.

Table 7 (Panel B) Number of STDs diagnosed in the past year

Number of STDs diagnosed in the past 12 months

\begin{tabular}{|c|c|c|c|c|c|c|}
\hline & Girls & $\begin{array}{l}\text { Girls: } \\
\text { White }\end{array}$ & $\begin{array}{l}\text { Girls: } \\
\text { Black }\end{array}$ & Boys & $\begin{array}{l}\text { Boys: } \\
\text { White }\end{array}$ & $\begin{array}{l}\text { Boys: } \\
\text { Black }\end{array}$ \\
\hline Self esteem & $\begin{array}{c}0.000 \\
(0.008)\end{array}$ & $\begin{array}{l}-0.004 \\
(0.003)\end{array}$ & $\begin{array}{c}0.003 \\
(0.006)\end{array}$ & $\begin{array}{c}0.006 \\
(0.006)\end{array}$ & $\begin{array}{c}0.000 \\
(0.002)\end{array}$ & $\begin{array}{c}0.001 \\
(0.006)\end{array}$ \\
\hline \multicolumn{7}{|l|}{ First stage: IVs } \\
\hline Mother's support & $\begin{array}{c}1.801 * * * \\
(0.178)\end{array}$ & . & . & $\begin{array}{c}1.703 * * * \\
(0.167)\end{array}$ & . & \\
\hline Personality attractiveness & $\begin{array}{c}0.334 \\
(0.228)\end{array}$ & . & . & $\begin{array}{c}0.299 \\
(0.206)\end{array}$ & . & . \\
\hline Subjective obesity & $\begin{array}{c}-1.156 * * * \\
(0.168)\end{array}$ & . & . & $\begin{array}{c}-0.816^{* * * *} \\
(0.194)\end{array}$ & . & . \\
\hline F-test: self-esteem & 50.41 & . & & 41.37 & r & \\
\hline Sargan overid: $p$ value & 0.09 & & & 0.80 & . & \\
\hline Durbin-Wu-Hausman & 0.00 & 0.58 & 0.37 & 0.09 & 0.86 & 0.67 \\
\hline Observations & 2000 & 1426 & 574 & 1656 & 1282 & 374 \\
\hline
\end{tabular}

Note: All control variables included (see list reported in Table 2.4). The number of STDs diagnosed for the sample of girls and boys (first and fourth columns) have been estimated by instrumental variable estimation; the remaining models by OLS. Asterisks indicate significance at $* 0.1 * * 0.05 * * * 0.01$ levels, respectively. 
Table 8 Probability of never/ just occasionally used condom in the past 12 months

Probability of never/just occasionally use condom

\begin{tabular}{|c|c|c|c|c|c|c|}
\hline & Girls & $\begin{array}{l}\text { Girls: } \\
\text { White } \\
\end{array}$ & $\begin{array}{l}\text { Girls: } \\
\text { Black }\end{array}$ & Boys & $\begin{array}{l}\text { Boys: } \\
\text { White }\end{array}$ & $\begin{array}{l}\text { Boys: } \\
\text { Black }\end{array}$ \\
\hline Self esteem & $\begin{array}{c}-0.016 * \\
(0.010)\end{array}$ & $\begin{array}{l}-0.018 \\
(0.012)\end{array}$ & $\begin{array}{c}-0.086 * \\
(0.049)\end{array}$ & $\begin{array}{c}0.275 * * * \\
(0.107)\end{array}$ & $\begin{array}{l}-0.005 \\
(0.014)\end{array}$ & $\begin{array}{l}-0.001 \\
(0.028)\end{array}$ \\
\hline Self esteem $` 2$ & 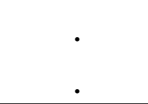 & . & . & $\begin{array}{c}0.007 * * * \\
(0.003)\end{array}$ & . & . \\
\hline$\overline{\text { IVs }}$ & & & & & & \\
\hline Mother's support & 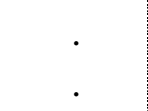 & . & $\begin{array}{c}2.533 * * * \\
(0.288)\end{array}$ & & . & . \\
\hline Personality attractiveness & . & . & $\begin{array}{c}0.016 \\
(0.373)\end{array}$ & & . & . \\
\hline Subjective obesity & . & . & $\begin{array}{c}-1.028 * * * \\
(0.282) \\
\end{array}$ & & . & . \\
\hline F-test: self-esteem & r & • & 21.75 & • & - & . \\
\hline Amemiya-Lee-Newey: p-value & . & . & 0.16 & 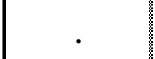 & & . \\
\hline Wald test (exogeneity) & 0.36 & 0.97 & 0.09 & 0.12 & 0.14 & 0.65 \\
\hline Observations & 1831 & 1316 & 515 & 1460 & 1119 & 341 \\
\hline
\end{tabular}

Note: All control variables included (see list reported in Table 2.4). All models have been estimated by probit model except the probability for black girls of never/just occasionally use condom (third column) which has been estimated by a probit model with endogenous regressors using maximum likelihood estimator. Marginal effects reported. Asterisks indicate significance at $* 0.1 * * 0.05 * * * 0.01$ levels, respectively. 
Figure 3 Probability of never/ just occasionally use condom

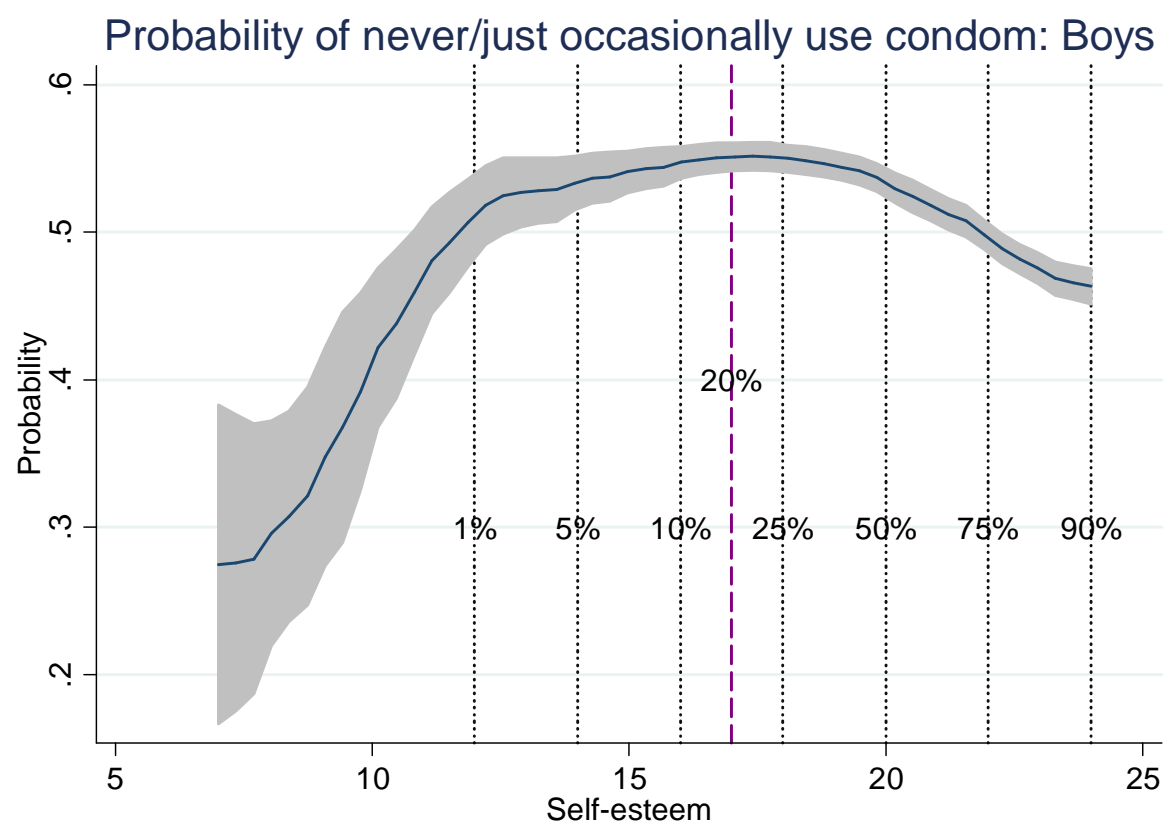

Note: The local polynomial smooth plot is based on a prediction computed using the estimated coefficients holding all control variables at their mean values (95\% confidence interval reported). Vertical lines in correspondence of the self-esteem's values for the $1^{\text {st }}, 5^{\text {th }}, 10^{\text {th }}, 25^{\text {th }}, 50^{\text {th }}, 75^{\text {th }}$ and $90^{\text {th }}$ (dashed lines) percentile of self-esteem's distribution for the sample considered in the estimation and of the $60^{\text {th }}$ and $64^{\text {th }}$ percentile of self-esteem at the upper inflection points (dotted line). 
Table 9 Probability of never/ just occasionally used any birth control method in the past 12 months

Probability of never/just occasionally use any birth control method

\begin{tabular}{|c|c|c|c|c|c|c|}
\hline & Girls & $\begin{array}{l}\text { Girls: } \\
\text { White }\end{array}$ & $\begin{array}{l}\text { Girls: } \\
\text { Black }\end{array}$ & Boys & $\begin{array}{l}\text { Boys: } \\
\text { White }\end{array}$ & $\begin{array}{l}\text { Boys: } \\
\text { Black }\end{array}$ \\
\hline Self esteem & $\begin{array}{l}-0.001 \\
(0.010)\end{array}$ & $\begin{array}{l}-0.005 \\
(0.012)\end{array}$ & $\begin{array}{c}-0.096^{*} \\
(0.053)\end{array}$ & $\begin{array}{l}-0.021 \\
(0.013)\end{array}$ & $\begin{array}{l}-0.025 \\
(0.015)\end{array}$ & $\begin{array}{l}-0.013 \\
(0.028)\end{array}$ \\
\hline \multicolumn{7}{|l|}{ IVs } \\
\hline Mother's support & . & . & $\begin{array}{c}2.533 * * * \\
(0.288)\end{array}$ & . & & . \\
\hline Personality attractiveness & . & 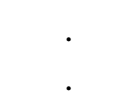 & $\begin{array}{c}0.016 \\
(0.373)\end{array}$ & . & . & \\
\hline Subjective obesity & . & . & $\begin{array}{c}-1.028 * * * \\
(0.282)\end{array}$ & . & . & . \\
\hline F-test: self-esteem & . & . & 22.66 & . & . & • \\
\hline Amemiya-Lee-Newey: p-value & . & & 0.16 & . & . & . \\
\hline Wald test (exogeneity) & 0.24 & 0.97 & 0.04 & 0.51 & 0.50 & 0.98 \\
\hline Observations & 1830 & 1316 & 514 & 1448 & 1110 & 338 \\
\hline
\end{tabular}

Note: All control variables included (see list reported in Table 2.4). All models have been estimated by probit model except the probability for black girls of never/just occasionally use any birth control method (third column) which has been estimated by a probit model with endogenous regressors using maximum likelihood estimator. Marginal effects reported. Asterisks indicate significance at * $0.1 * * 0.05 * * * 0.01$ levels, respectively. 


\section{References}

Alexander, T. 2001. "What is self-esteem and why does it matter? self-esteem as an aid to understanding and recovery." Mental Health and Learning Disabilities Care 4 (10):332335.

Almlund, M., A. Duckworth, J.J. Heckman, and T. Kautz. 2011. "Personality psychology and economics." In Handbook of the Economics of Education 4:1-181.

Amato, P.R. and G. Ochiltree. 1986. "Family resources and the development of child competence." Journal of Marriage and the Family 48 (1):47-56.

Amemiya, T. 1978. "The estimation of a simultaneous equation generalized probit model." Econometrica 46 (5):1193-1205.

American Social Health Association, ASHA. 2001. "STD Statistics." http://www.ashastd.org/std/stats/html .

Anderson, J.E. and L.L. Dahlberg. 1992. "High-risk sexual behavior in the general population. Results from a national survey, 1988-1990." Sexually Transmitted Diseases $19(6): 320$.

Ashcraft, A. and K. Lang. 2006. "The consequences of teenage childbearing." National Bureau of Economic Research Working Paper No. 12485 (No. 12485).

Ayduk, O., G. Downey, and M. Kim. 2001. "Rejection sensitivity and depressive symptoms in women." Personality and Social Psychology Bulletin 27 (7):868-877.

Bachman, J.G. 1970. The impact of family background and intelligence on tenth-grade boys, vol. 2. Institute for Social Research, University of Michigan.

-1978. Youth in transition. Adolescence to adulthood. Change and stability in the lives of young men. Ann Arbor, Institute for Social Research.

Bankston III, C.L. and M. Zhou. 2002. "Being well vs. doing well: self-esteem and school performance among immigrant and non immigrant racial and ethnic groups." International Migration Review 36 (2):389-415. 
Barber, B.K. and B.C. Rollins. 1990. Parent-adolescent relationships. University Press of America.

Baumeister, R.F. 1996. "Should schools try to boost self-esteem? Beware the dark side." American Educator 20 (2):14-19.

Baumeister, R.F., L. Smart, and J. Boden. 1996. "Relation of threatened egoism to violence and aggression: the dark side of high self esteem." Psychological Review 103 (1):533.

Billy, J.O.G., K.L. Brewster, and W.R. Grady. 1994. "Contextual effects on the sexual behavior of adolescent women." Journal of Marriage and the Family 56 (2):387-404.

Bingham, C.R. 1989. "AIDS and adolescents threat of infection and approaches for prevention." The Journal of Early Adolescence 9 (1-2):50-66.

Biro, F. M., R. H. Striegel-Moore, D. L. Franko, J. Padgett, and J. A. Bean. 2006. "Selfesteem in adolescent females." Journal of Adolescent Health 39 (4):501-507.

Block, J. 1971. Lives through time. Berkeley, CA: Bancroft Books.

Blumer, H. 1969. Symbolic interactionism. Englewood Cliffs, NJ: Prentice-Hall.

Borghans, L., A.L. Duckworth, and B. Heckman, J.J.and ter Weel. 2008. "The economics and psychology of personality traits." Journal of Human Resources 43 (4):972-1059.

Bowden, R.J. and D.A. Turkington. 1984. Instrumental variables, vol. 8. Cambridge University Press, New York.

Branden, N. 1994. The six pillars of self-esteem. Bantam Dell Pub Group.

Caspi, A. and G.H. Elder. 1988. "Emergent family patterns: the intergenerational construction of problem behavior and relationships." Relationships within families: mutual influences :218-240.

Centers for Disease Control and Prevention (CDC). 2000a. "Tracking the hidden epidemics: trends in STDs in the United States." http://www . cdc.gov/nchstp/dstd/Stats-Trends/Trends2000.pdf. 
- 2000b. "STDs in racial and ethnic minorities." http://wwww.cdc.gov/std/stats/TOC2000.htm.

- 2002. "HIV prevalence trends in selected populations in the united states: results from national sero surveillance 1993-1997." http://www . cdc.gov/nchstp/dstd/Stats-Trends/Trends2000.pdf.

Chen, X.K., S.W. Wen, N. Fleming, K. Demissie, G.G. Rhoads, and M. Walker. 2007. "Teenage pregnancy and adverse birth outcomes: a large population based retrospective cohort study." International Journal of Epidemiology 36 (2):368-373.

Coker, A.L., D.L. Richter, R.F. Valois, R.E. McKeown, C.Z. Garrison, and M.L. Vincent. 1994. "Correlates and consequences of early initiation of sexual intercourse." Journal of School Health 64 (9):372-377.

Conde-Agudelo, A., J.M. Belizán, and C. Lammers. 2005. "Maternal-perinatal morbidity and mortality associated with adolescent pregnancy in Latin America: Cross-sectional study." American Journal of Obstetrics and Gynecology 192 (2):342-349.

Conger, R.D., X. Ge, G.H. Elder Jr, F.O. Lorenz, and R.L. Simons. 1994. "Economic stress, coercive family process, and developmental problems of adolescents." Child development $65(2): 541-561$.

Conti, G. and J.J. Heckman. 2010. "Understanding the Early Origins of the EducationHealth Gradient." Perspectives on Psychological Science 5 (5):585-605.

Cooksey, E.C. and M.M. Fondell. 1996. "Spending time with his kids: effects of family structure on fathers' and children's lives." Journal of Marriage and the Family $58(3): 693-707$.

Costa Jr, P.T. and R.R. McCrae. 1992. NEO Personality Inventory-Revised (NEO-PI-R) and NEO Five-Factor Inventory (NEO-FFI) professional manual. Odessa, FL: Psychological Assessment Resources.

Crocker, J., K. Voelkl, M. Testa, and B. Major. 1991. "Social stigma: the affective consequences of attributional ambiguity." Journal of Personality and Social Psychology $60(2): 218$. 
Cronbach, L.J. 1946. "Response sets and test validity." Educational and psychological measurement 6 (4):475-494.

- 1950. "Further evidence on response sets and test design." Educational and Psychological Measurement 10 (3):3-31.

Cunha, F., J.J. Heckman, and S.M. Schennach. 2010. "Estimating the technology of cognitive and noncognitive skill formation." Econometrica 78 (3):883-931.

D'Augelli, AR, CR Bingham, and RM Lerner. 1993. "Interventions to prevent HIV infections in young adolescents." Early adolescence: Perspectives on research, policy, and intervention :353-368.

Davila, J., S.J. Steinberg, L. Kachadourian, R. Cobb, and F. Fincham. 2004. "Romantic involvement and depressive symptoms in early and late adolescence: the role of a preoccupied relational style." Personal Relationships 11 (2):161-178.

Day, R.D. 1992. "The transition to first intercourse among racially and culturally diverse youth." Journal of Marriage and the Family 54 (4):749-762.

Dornbusch, S.M., J.M. Carlsmith, S.J. Bushwall, P.L. Ritter, H. Leiderman, A.H. Hastorf, and R.T. Gross. 1985. "Single parents, extended households, and the control of adolescents." Child Development 56 (2):326-341.

Dryfoos, J.G. 1991. Adolescents at risk: prevalence and prevention. Oxford University Press, USA.

Duncan, G.J., J. Brooks-Gunn, and P.K. Klebanov. 1994. "Economic deprivation and early childhood development." Child development 65 (2):296-318.

Durbin, M., R.J. DiClemente, D. Siegel, F. Krasnovsky, N. Lazarus, and T. Camacho. 1993. "Factors associated with multiple sex partners among junior high school students." Journal of Adolescent Health 14 (3):202-207.

East, P.L. 1998. "Racial and ethnic differences in girls' sexual, marital, and birth expectations." Journal of Marriage and the Family 60 (1):150-162.

Elder Jr, G.H. and A. Caspi. 1988. "Economic stress in lives: developmental perspectives." Journal of Social Issues 44 (4):25-45. 
Emler, N. 2001. Self esteem: the costs and causes of low self worth. York Publishing Services.

Fergusson, DM, ME Dimond, and LJ Horwood. 1986. "Childhood family placement history and behaviour problems in 6-year-old children." Journal of Child Psychology and Psychiatry 27 (2):213-226.

Francesconi, M. 2008. "Adult outcomes for children of teenage mothers." The Scandinavian Journal of Economics 110 (1):93-117.

Friedman, H.L. 1989. "The health of adolescents: beliefs and behaviour." Social Science \& Medicine 29 (3):309-315.

Furstenberg Jr, F.F., S.P. Morgan, K.A. Moore, and J.L. Peterson. 1987. "Race differences in the timing of adolescent intercourse." American Sociological Review 52 (4):511-518.

Geronimus, A.T. and S. Korenman. 1993. "Maternal youth or family background? On the health disadvantages of infants with teenage mothers." American Journal of Epidemiology 137 (2):213-225.

Greene, W.H. 2000. Econometric analysis, vol. 5. Prentice-Hall, Upper Saddle River, NJ.

Grello, C.M., D.P. Welsh, and M.S. Harper. 2003. "No strings attached: the nature of casual sex in college students." Journal of Sex Research 43 (3):255-267.

Hahn, J. and J. Hausman. 2003. "Weak instruments: diagnosis and cures in empirical econometrics." The American Economic Review 93 (2):118-125.

Hallfors, D.D., M.W. Waller, D. Bauer, C.A. Ford, and C.T. Halpern. 2005. "Which comes first in adolescence: sex and drugs or depression?" American Journal of Preventive Medicine 29 (3):163-170.

Hashima, P.Y. and P.R. Amato. 1994. "Poverty, social support, and parental behavior." Child Development 65 (2):394-403.

Heckman, J.J., J. Stixrud, and S. Urzua. 2006. "The effects of cognitive and noncognitive abilities on labor market outcomes and social behavior." National Bureau of Economic Research :Working Paper No. 12006. 
Hofferth, S.L., J.R. Kahn, and W. Baldwin. 1987. "Premarital sexual activity among US teenage women over the past three decades." Family Planning Perspectives 19 (2):46-53.

Inazu, J.K. and G.L. Fox. 1980. "Maternal influence on the sexual behavior of teen-age daughters." Journal of Family Issues 1 (1):81-99.

Jessor, S.L. and R. Jessor. 1975. "Transition from virginity to non-virginity among youth: a social-psychological study over time." Developmental psychology 11 (4):473-484.

Joyner, K. and J.R. Udry. 2000. "You don't bring me anything but down: adolescent romance and depression." Journal of Health and Social Behavior 41 (4):369-391.

Judge, T.A., A. Erez, J.E. Bono, and C.J. Thoresen. 2002. "Are measures of self-esteem, neuroticism, locus of control, and generalized self-efficacy indicators of a common core construct?" Journal of personality and social psychology 83 (3):693-710.

Judge, T.A. and C. Hurst. 2007. "Capitalizing on one's advantages: role of core selfevaluations." Journal of Applied Psychology 92 (5):1212-1227.

Kahn, J.R., W.D. Kalsbeek, and S.L. Hofferth. 1988. "National estimates of teenage sexual activity: evaluating the comparability of three national surveys." Demography $25(2): 189-204$.

Kinsman, S.B., D. Romer, F.F. Furstenberg, and D.F. Schwarz. 1998. "Early sexual initiation: the role of peer norms." Pediatrics 102 (5):1185-1192.

Kirby, D. 2007. "Emerging answers 2007: research findings on programs to reduce teen pregnancy and sexually transmitted diseases. National campaign to prevent teen and unplanned pregnancy." Retrieved February 23:2009.

Ku, L., F.L. Sonenstein, and J.H. Pleck. 1993. "Factors influencing first intercourse for teenage men." Public Health Reports 108 (6):680-694.

Larson, R.W., G.L. Clore, and G.A. Wood. 1999. "The emotions of romantic relationships: Do they wreak havoc on adolescents." In W. Furman and B. B. Brown (Eds.), The development of romantic relationships in adolescence :19-49.

Laumann, E.O., J.H. Gagnon, R.T. Michael, and S. Michaels. 2000. The social organization of sexuality: Sexual practices in the United States. University of Chicago Press. 
Lawson, M.C. 1980. "Development of body build stereotypes, peer ratings, and selfesteem in Australian children." Journal of Psychology: Interdisciplinary and Applied $104(4): 111-118$.

Lee, L.F. 1992. “Amemiya's generalized least squares and tests of over identification in simultaneous equation models with qualitative or limited dependent variables." Econometric Reviews 11 (3):319-328.

Lehrer, J.A., L.A. Shrier, S. Gortmaker, and S. Buka. 2006. "Depressive symptoms as a longitudinal predictor of sexual risk behaviors among US middle and high school students." Pediatrics 118 (1):189-200.

Levine, J.A., H. Pollack, and M.E. Comfort. 2001. "Academic and behavioral outcomes among the children of young mothers." Journal of Marriage and Family 63 (2):355-369.

Longmore, M.A., W.D. Manning, P.C. Giordano, and J.L. Rudolph. 2004. "Self-esteem, depressive symptoms, and adolescents' sexual onset." Social Psychology Quarterly $67(3): 279-295$.

Luster, T. and H.P. McAdoo. 1994. "Factors related to the achievement and adjustment of young African American children." Child Development 65 (4):1080-1094.

Maynard, R.A. 1996. Kids having kids: A Robin Hood Foundation special report on the costs of adolescent childbearing. Robin Hood Foundation.

McCrae, R.R. and O.P. John. 1992. "An introduction to the five-factor model and its applications." Journal of personality 60 (2):175-215.

McGee, R. and S. Williams. 2000. "Does low self-esteem predict health compromising behaviours among adolescents?" Journal of Adolescence 23 (5):569-582.

McLeod, J.D. and M.J. Shanahan. 1993. "Poverty, parenting, and children's mental health." American Sociological Review 58 (3):351-366.

McLoyd, V.C. 1990. "The impact of economic hardship on Black families and children: Psychological distress, parenting, and socio-emotional development." Child development $61(2): 311-346$. 
Mead, G.H. 1934. Mind, self, and society: from the standpoint of a social behaviorist, vol. 1. The University of Chicago Press.

Meier, A.M. 2007. "Adolescent first sex and subsequent mental health." American Journal of Sociology 112 (6):1811-1847.

Meschke, L.L. and R.K. Silbereisen. 1997. "The influence of puberty, family processes, and leisure activities on the timing of first sexual experience." Journal of Adolescence $20(4): 403-418$.

Miller, B.C. and C.R. Bingham. 1989. "Family configuration in relation to the sexual behavior of female adolescents." Journal of Marriage and the Family 51 (2):499-506.

Miller, B.C. and K.A. Moore. 1990. "Adolescent sexual behavior, pregnancy, and parenting: research through the 1980s." Journal of Marriage and the Family 52 (4):1025-1044.

Newcomer, S. and J.R. Udry. 1987. "Parental marital status effects on adolescent sexual behavior." Journal of Marriage and the Family 49 (2):235-240.

Newey, W.K. 1987. "Efficient estimation of limited dependent variable models with endogenous explanatory variables." Journal of Econometrics 36 (3):231-250.

Ornelas, I.J., K.M. Perreira, and G.X. Ayala. 2007. "Parental influences on adolescent physical activity: a longitudinal study." International Journal of Behavioral Nutrition and Physical Activity 4 (1):3.

Orr, D.P., M.L. Wilbrandt, C.J. Brack, S.P. Rauch, and G.M. Ingersoll. 1989. "Reported sexual behaviors and self-esteem among young adolescents." Archives of Pediatrics and Adolescent Medicine 143 (1):86-90.

Pick, S. and P.A. Palos. 1995. "Impact of the family on the sex lives of adolescents." Adolescence 30 (119):667-667.

Rector, R.E., K.A. Johnson, L.R. Noyes, and S. Martin. 2002. "The harmful effects of early sexual activity and multiple sexual partners among women: a book of charts." Washington: The Heritage Foundation .

Roberts, R.E.L. and V.L. Bengtson. 1996. "Affective ties to parents in early adulthood and self-esteem across 20 years." Social Psychology Quarterly 59 (1):96-106. 
Robinson, R.B. and D.I. Frank. 1994. "The relation between self-esteem, sexual activity, and pregnancy." Adolescence 29 (113):27-27.

Rosenberg, M. 1965. Society and the adolescent self-image. Princeton, NJ: Princeton University Press.

1986. Conceiving the self. Krieger Malabar,Fla.

Rosenberg, M. and L.I. Pearlin. 1978. "Social class and self-esteem among children and adults." American Journal of Sociology 84 (1):53-77.

Rosenberg, M., C. Schooler, and C. Schoenbach. 1989. "Self-esteem and adolescent problems: modeling reciprocal effects." American Sociological Review 54 (6):1004-1018.

Rosenberg, M. and R.G. Simmons. 1972. Black and white self-esteem: the urban school child. American Sociological Association Washington, DC.

Ruud, P.A. 2000. An introduction to classical econometric theory. Oxford University Press.

Salazar, L.F., R.A. Crosby, R.J. DiClemente, G.M. Wingood, C.M. Lescano, L.K. Brown, K. Harrington, and S. Davies. 2005. "Self-esteem and theoretical mediators of safer sex among African American female adolescents: implications for sexual risk reduction interventions." Health Education \& Behavior 32 (3):413-427.

Santelli, J.S., RJ DiClemente, KS Miller, D. Kirby et al. 1999. "Sexually transmitted diseases, unintended pregnancy, and adolescent health promotion." Adolescent medicine $10(1): 87-108$.

Sargan, J.D. 1958. "The estimation of economic relationships using instrumental variables." Econometrica 26 (3):393-415.

Smith, E.A. and J.R. Udry. 1985. "Coital and non-coital sexual behaviors of white and black adolescents." American Journal of Public Health 75 (10):1200-1203.

Smith, T.W. 1991. "Adult sexual behavior in 1989: number of partners, frequency of intercourse and risk of AIDS." Family Planning Perspectives 23 (3):102-107. 
Snarey, J.R. 1993. How fathers care for the next generation: a four-decade study. Harvard University Press.

Spencer, J.M., G.D. Zimet, M.C. Aalsma, and D.P. Orr. 2002. "Self-esteem as a predictor of initiation of coitus in early adolescents." Pediatrics 109 (4):581-584.

Steinberg, L. 1987. "Single parents, stepparents, and the susceptibility of adolescents to antisocial peer pressure." Child Development 58 (1):269-275.

Stock, J. and D. Staiger. 1997. "Instrumental variables regression with weak instruments." Econometrica 65 (3):557-586.

Stock, J.H., J.H. Wright, and M. Yogo. 2002. "A survey of weak instruments and weak identification in generalized method of moments." Journal of business and economic statistics 20 (4):518-529.

Stock, J.H. and M. Yogo. 2002. "Testing for weak instruments in linear IV regression." NBER Technical Working Paper :No.0284.

Teachman, J., R. Day, K. Paasch, K. Carver, and V. Call. 1998. "Sibling resemblance in behavioral and cognitive outcomes: the role of father presence." Journal of Marriage and the Family 60 (4):835-848.

Thomas, D.L., V. Gecas, A. J. Weigert, and E. Rooney. 1974. Family socialization and the adolescent: determinants of self-concept, conformity, religiosity and counterculture values. Lexington Books.

Thornton, A. 1991. "Influence of the marital history of parents on the marital and cohabitational experiences of children." American Journal of Sociology 96 (4):868-894.

Thornton, A. and D. Camburn. 1987. "The influence of the family on premarital sexual attitudes and behavior." Demography 24 (3):323-340.

Wallerstein, J.S. 1985. "Children of divorce: emerging trends." Psychiatric Clinics of North America; Psychiatric Clinics of North America .

Walsh, A. 1991. "Self-esteem and sexual behavior: exploring gender differences." Sex Roles 25 (7):441-450. 
Wells, L.E. and J.H. Rankin. 1983. "Self-concept as a mediating factor in delinquency." Social Psychology Quarterly 46 (1):11-22.

Whitbeck, L.B., R.D. Conger, and M.Y. Kao. 1993. "The influence of parental support, depressed affect, and peers on the sexual behaviors of adolescent girls." Journal of family issues 14 (2):261-278.

Whitbeck, L.B., R.L. Simons, R.D. Conger, F.O. Lorenz, S. Huck, and G.H. Elder Jr. 1991. "Family economic hardship, parental support, and adolescent self-esteem." Social Psychology Quarterly 54 (4):353-363.

White, S.D. and R.R. DeBlassie. 1992. "Adolescent sexual behavior." Adolescence .

Wooldridge, J.M. 2002. Econometric analysis of cross section and panel data. The MIT press.

Young, E.W., L.C. Jensen, J.A. Olsen, and B.P. Cundick. 1991. "The effects of family structure on the sexual behavior of adolescents." Adolescence 26 (104):977-986.

Zelnik, M., J.F. Kantner, and K. Ford. 1981. Sex and pregnancy in adolescence. Sage Beverly Hills, CA.

Zimmerman, M.A., L.A. Copeland, J.T. Shope, and T.E. Dielman. 1997. "A longitudinal study of self-esteem: implications for adolescent development." Journal of youth and Adolescence 26 (2):117-141. 


\section{Appendix}

Table A1 Variables

\begin{tabular}{|c|c|}
\hline Age at first sexual intercourse & $\begin{array}{l}\text { "In what [month and] year did you have } \\
\text { sexual intercourse for the very first } \\
\text { time? When we say sexual intercourse, } \\
\text { we mean when a male inserts his penis } \\
\text { into a female's vagina". }\end{array}$ \\
\hline Adolescent Sexual Promiscuity & $\begin{array}{l}\text { With how many partners have you ever } \\
\text { had vaginal intercourse, even if only } \\
\text { once? }\end{array}$ \\
\hline Risk of Contracting a STD & $\begin{array}{l}\text { On how many of these occasions of } \\
\text { vaginal intercourse in the past } 12 \text { did } \\
\text { you or your partner use a condom? } \\
0=\text { Most, All; } 1=\text { None, Some, Half }\end{array}$ \\
\hline Use of Birth Control Methods & $\begin{array}{l}\text { On how many of these occasions of } \\
\text { vaginal intercourse in the past } 12 \\
\text { months did you or your partner use } \\
\text { some form of birth control or pregnancy } \\
\text { protection? } 0=\text { Most, All; } 1=\text { None, } \\
\text { Some, Half }\end{array}$ \\
\hline Diagnosed with STD & $\begin{array}{l}\text { In the past } 12 \text { month s, have you been } \\
\text { told by a doctor or nurse that you had } \\
\text { the following sexually transmitted } \\
\text { diseases? Chlamidya, gonorrhoea, } \\
\text { trichomoniasis, syphilis, genital herpes, } \\
\text { genital warts, human papilloma virus, } \\
\text { bacterial vaginosis, pelvic inflammatory } \\
\text { disease, cervicitis or muco purulent } \\
\text { cervicitis, urethritis, vaginitis, HIV } \\
\text { infection or AIDS or others. } \\
0=\text { No, } 1=\text { Yes, been diagnosed with at } \\
\text { least one STD. }\end{array}$ \\
\hline $\begin{array}{l}\text { Adolescent personality attractiveness } \\
\text { (asked to the interviewer) }\end{array}$ & $\begin{array}{l}\text { How attractive is the respondent's } \\
\text { personality? It takes values from } 1 \\
\text { ("Very unattractive"), to } 5 \text { ("Very } \\
\text { attractive"). }\end{array}$ \\
\hline Religion salience & $\begin{array}{l}\text { How important is religion to you? It } \\
\text { takes values } 0 \text { ("Not important at all"), } \\
1 \text { ("Fairly important") and } 2 \text { ("Very } \\
\text { important"). }\end{array}$ \\
\hline
\end{tabular}


In the past 12 months, how often did you attend religious services? It takes values from 0 ("Never") to 4 ("Once a week or more"). 
Table A2 Age of sexual debut

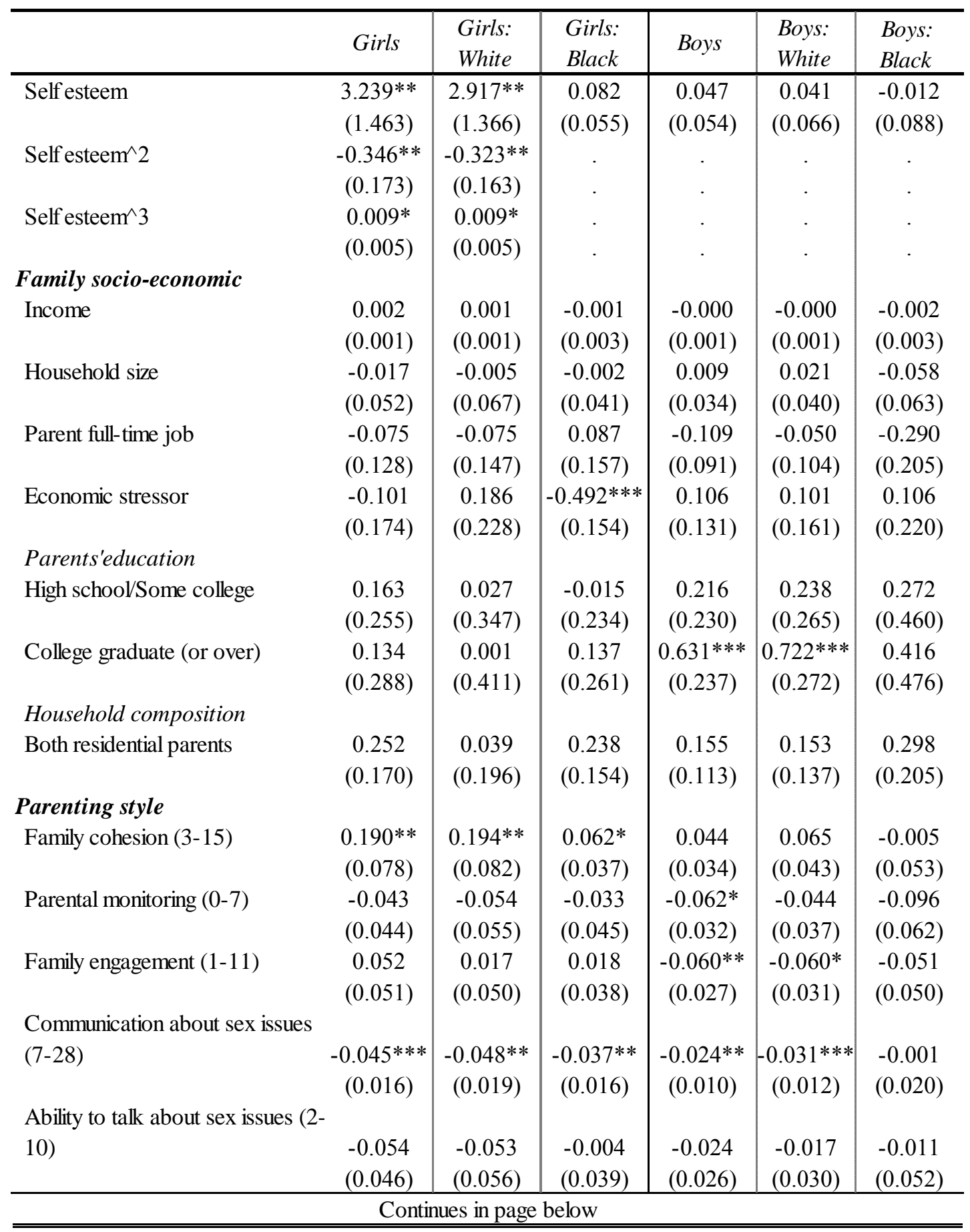




\begin{tabular}{|c|c|c|c|c|c|c|}
\hline \multicolumn{7}{|c|}{ Continues from page above } \\
\hline \multicolumn{7}{|l|}{ Religion value } \\
\hline Faily important & $\begin{array}{l}0.912 * \\
(0.547)\end{array}$ & $\begin{array}{l}0.925^{*} \\
(0.540)\end{array}$ & $\begin{array}{c}-0.364 * * \\
(0.161)\end{array}$ & $\begin{array}{l}-0.026 \\
(0.243)\end{array}$ & $\begin{array}{l}-0.163 \\
(0.259)\end{array}$ & $\begin{array}{c}0.917 \\
(0.712)\end{array}$ \\
\hline Very important & $\begin{array}{c}1.080 * * \\
(0.528)\end{array}$ & $\begin{array}{l}0.950 * \\
(0.496)\end{array}$ & & $\begin{array}{c}0.141 \\
(0.252)\end{array}$ & $\begin{array}{c}0.001 \\
(0.272)\end{array}$ & $\begin{array}{c}1.095 \\
(0.707)\end{array}$ \\
\hline \multicolumn{7}{|l|}{ Religion attendance } \\
\hline Once per month & $\begin{array}{l}-0.070 \\
(0.240)\end{array}$ & $\begin{array}{l}-0.209 \\
(0.261)\end{array}$ & $\begin{array}{l}0.618 * \\
(0.374)\end{array}$ & $\begin{array}{l}-0.055 \\
(0.146)\end{array}$ & $\begin{array}{l}-0.079 \\
(0.158)\end{array}$ & $\begin{array}{c}0.069 \\
(0.391)\end{array}$ \\
\hline Once per week or more & $\begin{array}{c}0.360 \\
(0.257)\end{array}$ & $\begin{array}{c}0.403 \\
(0.267)\end{array}$ & $\begin{array}{c}0.854 * * \\
(0.379)\end{array}$ & $\begin{array}{c}0.276^{*} \\
(0.152)\end{array}$ & $\begin{array}{l}0.324^{*} \\
(0.167)\end{array}$ & $\begin{array}{c}0.112 \\
(0.386)\end{array}$ \\
\hline \multicolumn{7}{|l|}{ Child demographic } \\
\hline Age & $\begin{array}{c}0.590 * * * \\
(0.041)\end{array}$ & $\begin{array}{c}0.654 * * * \\
(0.053)\end{array}$ & $\begin{array}{c}0.488 * * * \\
(0.043)\end{array}$ & $\begin{array}{c}0.619 * * * \\
(0.031)\end{array}$ & $\begin{array}{c}0.619 * * * \\
(0.035)\end{array}$ & $\begin{array}{c}0.564 * * * \\
(0.063)\end{array}$ \\
\hline Ethnicity: Black & $\begin{array}{l}-0.145 \\
(0.217)\end{array}$ & . & . & $\begin{array}{c}-0.553 * * * \\
(0.117)\end{array}$ & . & . \\
\hline \multicolumn{7}{|l|}{ Health and attractiveness } \\
\hline Poor health* disability & $\begin{array}{l}-1.160 \\
(0.933)\end{array}$ & $\begin{array}{c}-2.703 * \\
(1.387)\end{array}$ & $\begin{array}{c}0.619 \\
(0.652)\end{array}$ & $\begin{array}{c}0.788 \\
(0.592)\end{array}$ & $\begin{array}{c}0.229 \\
(0.788)\end{array}$ & $\begin{array}{l}1.635^{*} \\
(0.939)\end{array}$ \\
\hline Obese & $\begin{array}{c}0.905^{* * *} * \\
(0.328)\end{array}$ & $\begin{array}{c}0.534 \\
(0.556)\end{array}$ & $\begin{array}{c}0.989 * * * \\
(0.253)\end{array}$ & $\begin{array}{c}0.312 \\
(0.253)\end{array}$ & $\begin{array}{c}0.335 \\
(0.313)\end{array}$ & $\begin{array}{c}0.197 \\
(0.424)\end{array}$ \\
\hline Underweight & $\begin{array}{c}0.196 \\
(0.254)\end{array}$ & $\begin{array}{c}0.373 \\
(0.282)\end{array}$ & $\begin{array}{c}0.179 \\
(0.356)\end{array}$ & $\begin{array}{c}0.494 * * \\
(0.201)\end{array}$ & $\begin{array}{c}0.497 * * \\
(0.215)\end{array}$ & $\begin{array}{c}0.434 \\
(0.572)\end{array}$ \\
\hline Attractive (2-10) & $\begin{array}{l}-0.049 \\
(0.040)\end{array}$ & $\begin{array}{c}-0.095 * \\
(0.051)\end{array}$ & $\begin{array}{l}-0.009 \\
(0.042)\end{array}$ & $\begin{array}{c}-0.066^{* *} \\
(0.034)\end{array}$ & $\begin{array}{l}-0.045 \\
(0.039)\end{array}$ & $\begin{array}{l}-0.098 \\
(0.067)\end{array}$ \\
\hline \multicolumn{7}{|l|}{ School attainment } \\
\hline Grade (1-4) & $\begin{array}{c}0.419 * * * \\
(0.099) \\
\end{array}$ & $\begin{array}{c}0.467^{* * *} * \\
(0.116) \\
\end{array}$ & $\begin{array}{c}0.247 * * \\
(0.101) \\
\end{array}$ & $\begin{array}{c}0.353 * * * \\
(0.060) \\
\end{array}$ & $\begin{array}{c}0.382 * * * \\
(0.068) \\
\end{array}$ & $\begin{array}{c}0.181 \\
(0.127) \\
\end{array}$ \\
\hline \multicolumn{7}{|l|}{ IVs } \\
\hline Maternal support & $\begin{array}{c}1.872 * * * \\
(0.134)\end{array}$ & $\begin{array}{l}1.548 * * * \\
(0.188)\end{array}$ & $\begin{array}{c}2.533 * * * \\
(0.288)\end{array}$ & $\begin{array}{l}1.593 * * * \\
(0.125)\end{array}$ & $\begin{array}{l}1.501 * * * \\
(0.178)\end{array}$ & $\begin{array}{c}2.112 * * * \\
(0.310)\end{array}$ \\
\hline Personality attractiveness & $\begin{array}{c}0.165 \\
(0.170)\end{array}$ & $\begin{array}{l}0.430^{*} \\
(0.239)\end{array}$ & $\begin{array}{c}0.016 \\
(0.373)\end{array}$ & $\begin{array}{l}0.245 \\
(0.162)\end{array}$ & $\begin{array}{l}0.130 \\
(0.225)\end{array}$ & $\begin{array}{c}0.773 * * \\
(0.389)\end{array}$ \\
\hline Subjective obesity & $\begin{array}{c}-1.197 * * * \\
(0.125) \\
\end{array}$ & $\begin{array}{l}-1.322 * * * \\
(0.174) \\
\end{array}$ & $\begin{array}{c}-1.028 * * * \\
(0.282) \\
\end{array}$ & $\begin{array}{l}-1.074 * * * \\
(0.143)\end{array}$ & $\begin{array}{l}-1.045^{* * *} \\
(0.200)\end{array}$ & $\begin{array}{c}-0.719 * \\
(0.419) \\
\end{array}$ \\
\hline F-test: self-esteem & 70.01 & 43.40 & 29.13 & 48.41 & 47.48 & 18.80 \\
\hline Sargan overid: $p$ value & . & . & 0.47 & 0.09 & 0.10 & 0.63 \\
\hline Durbin-Wu-Hausman & 0.01 & 0.09 & 0.00 & 0.05 & 0.04 & 0.05 \\
\hline Observations & 2,000 & 1,426 & 574 & 1,656 & 1282 & 374 \\
\hline
\end{tabular}

Note: All control variables included. All models in the table have been estimated by instrumental variable estimation. Asterisks indicate significance at $* 0.1 * * 0.05 * * * 0.01$ levels, respectively. The Sargan test is missing where there are no over- identifying restrictions to be tested (number of instruments is equal to the number of endogenous variables). 
Table A3 Number of sexual partners

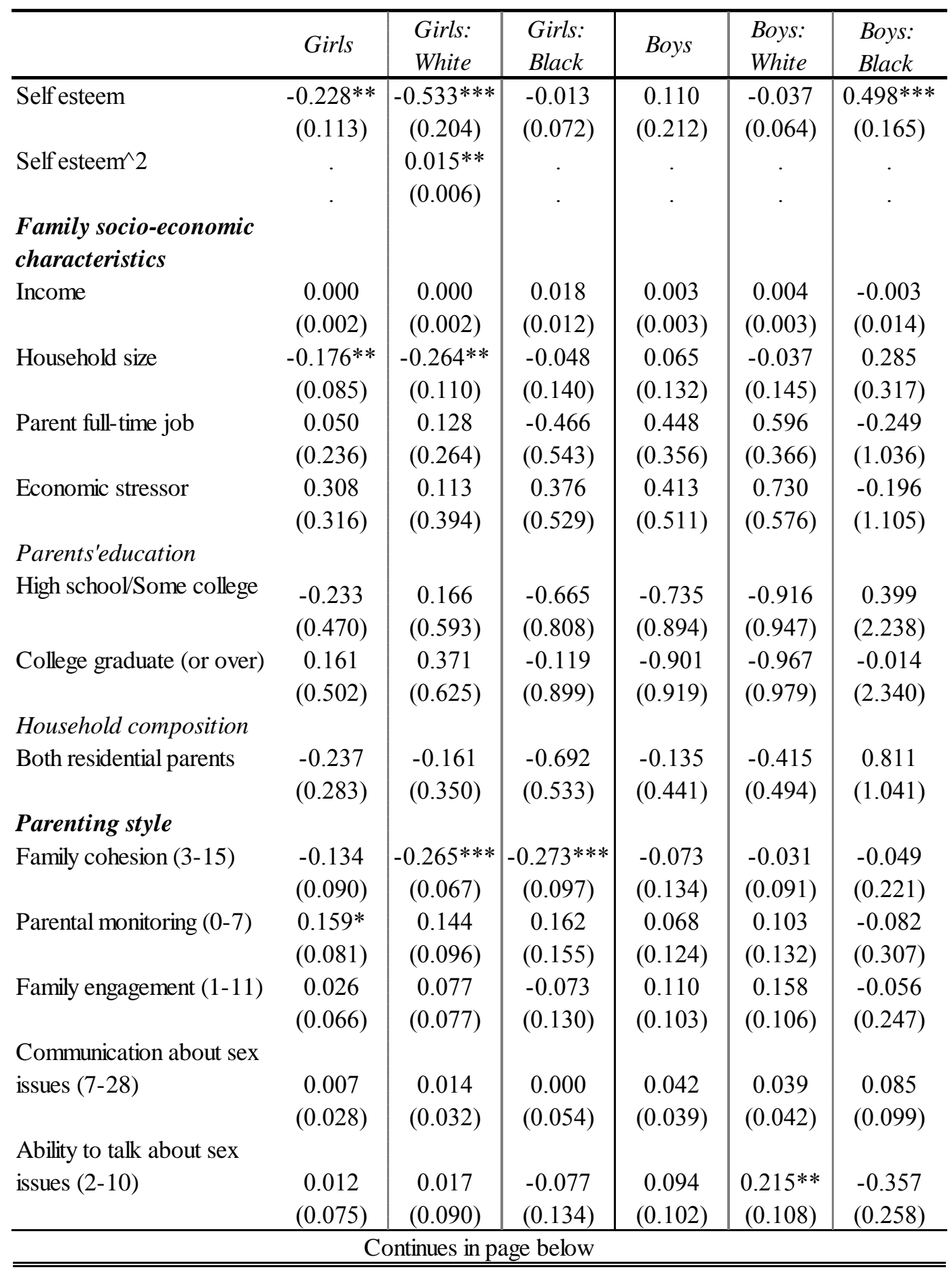




\begin{tabular}{|c|c|c|c|c|c|c|}
\hline \multicolumn{7}{|c|}{ Continues from page above } \\
\hline \multicolumn{7}{|l|}{ Religion value } \\
\hline Faily important & $\begin{array}{c}-1.520^{* *} \\
(0.750)\end{array}$ & $\begin{array}{c}-1.497 * * \\
(0.731)\end{array}$ & $\begin{array}{c}0.732 \\
(0.556)\end{array}$ & $\begin{array}{l}1.038 \\
(0.944)\end{array}$ & $\begin{array}{c}0.696 \\
(0.931)\end{array}$ & $\begin{array}{r}2.620 \\
(3.575)\end{array}$ \\
\hline Very important & $\begin{array}{c}-1.812 * * \\
(0.775)\end{array}$ & $\begin{array}{c}-1.739 * * \\
(0.764)\end{array}$ & 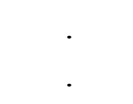 & $\begin{array}{l}0.971 \\
(0.979)\end{array}$ & $\begin{array}{c}0.879 \\
(0.979)\end{array}$ & $\begin{array}{c}1.841 \\
(3.554)\end{array}$ \\
\hline \multicolumn{7}{|l|}{ Religion attendance } \\
\hline Once per month & $\begin{array}{c}0.636 \\
(0.419)\end{array}$ & $\begin{array}{l}0.782 * \\
(0.436)\end{array}$ & $\begin{array}{c}0.019 \\
(1.283)\end{array}$ & $\begin{array}{l}-0.292 \\
(0.569)\end{array}$ & $\begin{array}{l}-0.134 \\
(0.569)\end{array}$ & $\begin{array}{l}-2.197 \\
(1.947)\end{array}$ \\
\hline Once per week or more & $\begin{array}{l}0.068 \\
(0.443)\end{array}$ & $\begin{array}{c}0.130 \\
(0.467)\end{array}$ & $\begin{array}{l}-0.159 \\
(1.299)\end{array}$ & $\begin{array}{c}-1.353 * * \\
(0.591)\end{array}$ & $\begin{array}{c}-1.322 * * \\
(0.602)\end{array}$ & $\begin{array}{l}-2.673 \\
(1.938)\end{array}$ \\
\hline \multicolumn{7}{|l|}{$\begin{array}{l}\text { Child demographic } \\
\text { charactheristics }\end{array}$} \\
\hline Age & $\begin{array}{c}-0.226 * * * \\
(0.073)\end{array}$ & $\begin{array}{c}-0.260 * * * \\
(0.083)\end{array}$ & $\begin{array}{l}-0.062 \\
(0.147)\end{array}$ & $\begin{array}{l}0.059 \\
(0.119)\end{array}$ & $\begin{array}{l}-0.041 \\
(0.125)\end{array}$ & $\begin{array}{c}0.418 \\
(0.300)\end{array}$ \\
\hline Ethnicity: Black & $\begin{array}{c}0.939 * * * \\
(0.335)\end{array}$ & 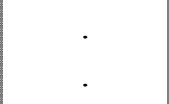 & 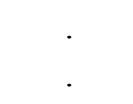 & $\begin{array}{c}2.306^{* * *} \\
(0.457)\end{array}$ & & \\
\hline \multicolumn{7}{|l|}{$\begin{array}{l}\text { Health and } \\
\text { attractiveness }\end{array}$} \\
\hline Poor health* disability & $\begin{array}{l}-1.201 \\
(1.341)\end{array}$ & $\begin{array}{c}0.558 \\
(1.707)\end{array}$ & $\begin{array}{l}-2.928 \\
(2.236)\end{array}$ & $\begin{array}{l}1.271 \\
(2.296)\end{array}$ & $\begin{array}{c}2.862 \\
(2.824)\end{array}$ & $\begin{array}{l}-4.786 \\
(4.498)\end{array}$ \\
\hline Obese & $\begin{array}{c}0.369 \\
(0.610)\end{array}$ & $\begin{array}{c}0.392 \\
(0.961)\end{array}$ & $\begin{array}{c}0.934 \\
(0.833)\end{array}$ & $\begin{array}{l}0.419 \\
(0.982)\end{array}$ & $\begin{array}{c}0.055 \\
(1.126)\end{array}$ & $\begin{array}{c}2.224 \\
(2.121)\end{array}$ \\
\hline Underweight & $\begin{array}{l}-0.197 \\
(0.470)\end{array}$ & $\begin{array}{l}-0.294 \\
(0.498)\end{array}$ & $\begin{array}{c}0.099 \\
(1.250)\end{array}$ & $\begin{array}{c}-2.249 * * * \\
(0.796)\end{array}$ & $\begin{array}{c}-1.974 * * \\
(0.781)\end{array}$ & $\begin{array}{l}-4.935^{*} \\
(2.956)\end{array}$ \\
\hline Attractive (2-10) & $\begin{array}{c}0.072 \\
(0.075)\end{array}$ & $\begin{array}{l}-0.017 \\
(0.087)\end{array}$ & $\begin{array}{c}0.193 \\
(0.144)\end{array}$ & $\begin{array}{l}0.095 \\
(0.131)\end{array}$ & $\begin{array}{c}0.119 \\
(0.131)\end{array}$ & $\begin{array}{c}0.107 \\
(0.336)\end{array}$ \\
\hline \multicolumn{7}{|l|}{ School attainment } \\
\hline Grade (1-4) & $\begin{array}{r}-0.295^{*} \\
(0.161) \\
\end{array}$ & $\begin{array}{c}-0.517 * * * \\
(0.176) \\
\end{array}$ & $\begin{array}{c}0.138 \\
(0.338) \\
\end{array}$ & $\begin{array}{l}-0.408^{*} \\
(0.234) \\
\end{array}$ & \begin{tabular}{|c}
$-0.599 * *$ \\
$(0.242)$ \\
\end{tabular} & $\begin{array}{r}0.579 \\
(0.637) \\
\end{array}$ \\
\hline
\end{tabular}

IVs

\begin{tabular}{lc|c|c|c|c|c}
\hline Maternal support & $1.875^{* * *}$ & $\cdot$ & $\cdot$ & $1.639 * * *$ & $\cdot$ & $\cdot$ \\
Personality attractiveness & $(0.157)$ & $\cdot$ & $\cdot$ & $(0.153)$ & $\cdot$ & $\cdot$ \\
& $(0.293$ & $\cdot$ & $\cdot$ & 0.269 & $\cdot$ & $\cdot$ \\
Subjective obesity & $-1.205^{* * *}$ & $\cdot$ & $\cdot$ & $(0.194)$ & $\cdot$ & $\cdot$ \\
& $(0.148)$ & $\cdot$ & $\cdot$ & $-0.990^{* * *}$ & $\cdot$ & $\cdot$ \\
\hline F-test: self-esteem & 68.94 & $\cdot$ & $\cdot$ & $(0.178)$ & $\cdot$ & $\cdot$ \\
Sargan overid: $p$ value & 0.19 & $\cdot$ & $\cdot$ & 0.87 .90 & $\cdot$ & $\cdot$ \\
Durbin-Wu-Hausman & 0.06 & 0.74 & 0.26 & 0.07 &. &. \\
\hline Observations & 1,984 & 1,420 & 564 & 1,641 & 1274 & 0.29 \\
\hline
\end{tabular}

Note: All control variables included. Asterisks indicate significance at $* 0.1 * * 0.05 * * * 0.01$ levels, respectively. The number of sexual partners for the sample of girls and boys (first and fourth columns) have been estimated by instrumental variable estimation; the remaining models by OLS. The Sargan test is missing where there are no over- identifying restrictions to be tested (number of instruments is equal to the number of endogenous variables). 
Table A4 Probability of have been diagnosed with at least one STD in the past year (Panel A)

\begin{tabular}{|c|c|c|c|c|c|c|}
\hline & Girls & $\begin{array}{l}\text { Girls: } \\
\text { White }\end{array}$ & $\begin{array}{l}\text { Girls: } \\
\text { Black }\end{array}$ & Boys & $\begin{array}{l}\text { Boys: } \\
\text { White }\end{array}$ & $\begin{array}{l}\text { Boys: } \\
\text { Black }\end{array}$ \\
\hline$\overline{\text { Self e }}$ & $\begin{array}{l}-0.010 \\
(0.011)\end{array}$ & $\begin{array}{l}-0.020 \\
(0.014)\end{array}$ & $\begin{array}{c}0.008 \\
(0.018)\end{array}$ & $\begin{array}{c}0.001 \\
(0.021)\end{array}$ & $\begin{array}{l}-0.006 \\
(0.027)\end{array}$ & $\begin{array}{c}0.007 \\
(0.038)\end{array}$ \\
\hline \multicolumn{7}{|l|}{$\begin{array}{l}\text { Family socio-economic } \\
\text { characteristics }\end{array}$} \\
\hline Income & $\begin{array}{l}0.000 \\
(0.001)\end{array}$ & $\begin{array}{c}0.001 \\
(0.001)\end{array}$ & $\begin{array}{c}0.001 \\
(0.003)\end{array}$ & $\begin{array}{l}0.001 * \\
(0.001)\end{array}$ & $\begin{array}{c}0.001 \\
(0.001)\end{array}$ & $\begin{array}{c}0.000 \\
(0.003)\end{array}$ \\
\hline Household size & $\begin{array}{l}-0.042 \\
(0.027)\end{array}$ & $\begin{array}{c}-0.068^{*} \\
(0.040)\end{array}$ & $\begin{array}{l}-0.028 \\
(0.038)\end{array}$ & $\begin{array}{l}0.026 \\
(0.045)\end{array}$ & $\begin{array}{l}-0.009 \\
(0.067)\end{array}$ & $\begin{array}{c}0.075 \\
(0.072)\end{array}$ \\
\hline Parent full-time job & $\begin{array}{l}-0.056 \\
(0.075)\end{array}$ & $\begin{array}{l}-0.005 \\
(0.093)\end{array}$ & $\begin{array}{l}-0.169 \\
(0.143)\end{array}$ & $\begin{array}{l}0.088 \\
(0.131)\end{array}$ & $\begin{array}{c}0.114 \\
(0.170)\end{array}$ & $\begin{array}{l}-0.002 \\
(0.234)\end{array}$ \\
\hline Economic stressor & $\begin{array}{l}0.013 \\
(0.096)\end{array}$ & $\begin{array}{l}0.101 \\
(0.142)\end{array}$ & $\begin{array}{l}-0.055 \\
(0.138)\end{array}$ & $\begin{array}{l}-0.056 \\
(0.172)\end{array}$ & $\begin{array}{c}0.006 \\
(0.264)\end{array}$ & $\begin{array}{l}-0.043 \\
(0.253)\end{array}$ \\
\hline \multicolumn{7}{|l|}{ Parents'education } \\
\hline High s & $\begin{array}{c}0.068 \\
(0.149)\end{array}$ & $\begin{array}{c}0.021 \\
(0.211)\end{array}$ & $\begin{array}{c}0.130 \\
(0.217)\end{array}$ & $\begin{array}{l}-0.132 \\
(0.303)\end{array}$ & $\begin{array}{l}-0.311 \\
(0.372)\end{array}$ & $\begin{array}{c}0.222 \\
(0.591)\end{array}$ \\
\hline Colleg & $\begin{array}{l}-0.010 \\
(0.159)\end{array}$ & $\begin{array}{l}-0.018 \\
(0.222)\end{array}$ & $\begin{array}{l}-0.002 \\
(0.240)\end{array}$ & $\begin{array}{l}-0.143 \\
(0.316)\end{array}$ & $\begin{array}{l}-0.201 \\
(0.386)\end{array}$ & $\begin{array}{c}0.188 \\
(0.614)\end{array}$ \\
\hline Househ & & & & & & \\
\hline Both $\mathrm{r}$ & $\begin{array}{l}0.079 \\
(0.089)\end{array}$ & $\begin{array}{c}0.169 \\
(0.126)\end{array}$ & $\begin{array}{c}0.002 \\
(0.140)\end{array}$ & $\begin{array}{l}0.151 \\
(0.156)\end{array}$ & $\begin{array}{c}0.078 \\
(0.223)\end{array}$ & $\begin{array}{c}0.253 \\
(0.241)\end{array}$ \\
\hline \multicolumn{7}{|l|}{ Parenting style } \\
\hline Family cohesion (3-15) & $\begin{array}{c}-0.047 * * * \\
(0.017)\end{array}$ & $\begin{array}{c}-0.049 * * \\
(0.023)\end{array}$ & $\begin{array}{c}-0.050^{* *} \\
(0.025)\end{array}$ & $\begin{array}{c}-0.072 * * \\
(0.029)\end{array}$ & $\left|\begin{array}{c}-0.121 * * * \\
(0.038)\end{array}\right|$ & $\begin{array}{c}0.004 \\
(0.050)\end{array}$ \\
\hline Parent & $\begin{array}{l}0.034 \\
(0.026)\end{array}$ & $\begin{array}{l}0.017 \\
(0.034)\end{array}$ & $\begin{array}{l}0.070^{*} \\
(0.042)\end{array}$ & $\begin{array}{l}-0.048 \\
(0.041)\end{array}$ & $\begin{array}{c}-0.093 * \\
(0.054)\end{array}$ & $\begin{array}{l}-0.002 \\
(0.069)\end{array}$ \\
\hline Family & $\begin{array}{l}-0.007 \\
(0.021)\end{array}$ & $\begin{array}{l}-0.004 \\
(0.027)\end{array}$ & $\begin{array}{l}-0.008 \\
(0.034)\end{array}$ & $\begin{array}{l}-0.042 \\
(0.037)\end{array}$ & $\begin{array}{l}-0.006 \\
(0.050)\end{array}$ & $\begin{array}{l}-0.080 \\
(0.059)\end{array}$ \\
\hline $\begin{array}{l}\text { Communication about sex } \\
\text { issues (7-28) }\end{array}$ & $\begin{array}{l}-0.005 \\
(0.009)\end{array}$ & $\begin{array}{l}-0.013 \\
(0.011)\end{array}$ & $\begin{array}{c}0.009 \\
(0.014)\end{array}$ & $\begin{array}{l}0.012 \\
(0.014)\end{array}$ & $\begin{array}{c}0.005 \\
(0.019)\end{array}$ & $\begin{array}{c}0.029 \\
(0.024)\end{array}$ \\
\hline $\begin{array}{l}\text { Ability to talk about sex } \\
\text { issues }(2-10)\end{array}$ & $\begin{array}{c}0.030 \\
(0.023)\end{array}$ & $\begin{array}{c}0.036 \\
(0.032)\end{array}$ & $\begin{array}{c}0.030 \\
(0.036)\end{array}$ & $\begin{array}{c}0.029 \\
(0.037)\end{array}$ & $\begin{array}{c}0.058 \\
(0.050)\end{array}$ & $\begin{array}{l}-0.028 \\
(0.059) \\
\end{array}$ \\
\hline
\end{tabular}




\begin{tabular}{|c|c|c|c|c|c|c|}
\hline \multicolumn{7}{|c|}{ Continues from page above } \\
\hline \multicolumn{7}{|l|}{ Religion value } \\
\hline Faily important & $\begin{array}{l}-0.091 \\
(0.243)\end{array}$ & $\begin{array}{l}-0.057 \\
(0.248)\end{array}$ & $\begin{array}{c}0.116 \\
(0.144)\end{array}$ & $\begin{array}{l}-0.145 \\
(0.319)\end{array}$ & $\begin{array}{l}-0.070 \\
(0.349)\end{array}$ & $\begin{array}{c}4.667^{* * *} \\
(0.235)\end{array}$ \\
\hline Very important & $\begin{array}{l}-0.012 \\
(0.251)\end{array}$ & $\begin{array}{c}0.115 \\
(0.261)\end{array}$ & . & $\begin{array}{l}-0.130 \\
(0.332)\end{array}$ & $\begin{array}{l}-0.094 \\
(0.376)\end{array}$ & $\begin{array}{l}4.705 \\
(0.334)\end{array}$ \\
\hline \multicolumn{7}{|l|}{ Religion attendance } \\
\hline Once per month & $\begin{array}{l}0.124 \\
(0.140)\end{array}$ & $\begin{array}{c}0.050 \\
(0.153)\end{array}$ & $\begin{array}{c}0.434 \\
(0.375)\end{array}$ & $\begin{array}{c}0.224 \\
(0.219)\end{array}$ & $\begin{array}{c}0.126 \\
(0.239)\end{array}$ & $\begin{array}{l}5.085^{* *} \\
(2.037)\end{array}$ \\
\hline Once per week or more & $\begin{array}{l}0.015 \\
(0.148)\end{array}$ & $\begin{array}{l}-0.081 \\
(0.166)\end{array}$ & $\begin{array}{c}0.323 \\
(0.382)\end{array}$ & $\begin{array}{l}0.002 \\
(0.231)\end{array}$ & $\begin{array}{l}-0.333 \\
(0.276)\end{array}$ & $\begin{array}{c}5.047 * * \\
(2.051)\end{array}$ \\
\hline \multicolumn{7}{|l|}{$\begin{array}{l}\text { Child demographic } \\
\text { charactheristics }\end{array}$} \\
\hline Age & $\begin{array}{l}-0.035 \\
(0.023)\end{array}$ & $\begin{array}{l}-0.032 \\
(0.029)\end{array}$ & $\begin{array}{l}-0.037 \\
(0.039)\end{array}$ & $\begin{array}{l}0.063 \\
(0.041)\end{array}$ & $\begin{array}{c}0.072 \\
(0.055)\end{array}$ & $\begin{array}{c}0.067 \\
(0.067)\end{array}$ \\
\hline Ethnicity: Black & $\begin{array}{c}0.589 * * * \\
(0.088)\end{array}$ & . & . & $\begin{array}{c}0.644 * * * \\
(0.144)\end{array}$ & 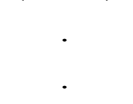 & . \\
\hline \multicolumn{7}{|l|}{$\begin{array}{l}\text { Health and } \\
\text { attractiveness }\end{array}$} \\
\hline Poor health* disability & $\begin{array}{l}-0.474 \\
(0.518)\end{array}$ & $\begin{array}{l}-0.004 \\
(0.589)\end{array}$ & . & . & & . \\
\hline Obese & $\begin{array}{l}-0.103 \\
(0.188)\end{array}$ & $\begin{array}{l}-0.281 \\
(0.391)\end{array}$ & $\begin{array}{l}-0.003 \\
(0.225)\end{array}$ & $\begin{array}{l}-0.388 \\
(0.445)\end{array}$ & $\begin{array}{c}0.091 \\
(0.496)\end{array}$ & . \\
\hline Underweight & $\begin{array}{l}-0.064 \\
(0.155)\end{array}$ & $\begin{array}{c}0.056 \\
(0.171)\end{array}$ & $\begin{array}{l}-0.603 \\
(0.401)\end{array}$ & $\begin{array}{l}-0.046 \\
(0.331)\end{array}$ & $\begin{array}{l}-0.285 \\
(0.466)\end{array}$ & $\begin{array}{c}0.350 \\
(0.599)\end{array}$ \\
\hline Attractive (2-10) & $\begin{array}{c}0.059^{* *} \\
(0.024)\end{array}$ & $\begin{array}{c}0.048 \\
(0.031)\end{array}$ & $\begin{array}{l}0.073^{*} \\
(0.038)\end{array}$ & $\begin{array}{l}0.001 \\
(0.046)\end{array}$ & $\begin{array}{l}-0.016 \\
(0.062)\end{array}$ & $\begin{array}{c}0.057 \\
(0.077)\end{array}$ \\
\hline School attainment & & & & & & \\
\hline Grade (1-4) & $\begin{array}{l}-0.017 \\
(0.050) \\
\end{array}$ & $\begin{array}{l}-0.050 \\
(0.061) \\
\end{array}$ & $\begin{array}{c}0.052 \\
(0.088) \\
\end{array}$ & $\begin{array}{l}-0.077 \\
(0.082) \\
\end{array}$ & $\begin{array}{l}-0.086 \\
(0.107) \\
\end{array}$ & $\begin{array}{l}-0.037 \\
(0.142) \\
\end{array}$ \\
\hline Wald test (exogeneity) & 0.76 & 0.94 & 0.49 & 0.28 & 0.13 & 0.77 \\
\hline Pseudo R-squared & 0.06 & 0.10 & 0.03 & 0.04 & 0.12 & 0.07 \\
\hline Observations & 2000 & 1426 & 568 & 1647 & 1275 & 354 \\
\hline
\end{tabular}

Note: All control variables included. All models in the table have been estimated by probit model. Marginal effects reported. Asterisks indicate significance at $* 0.1 * * 0.05 * * * 0.01$ levels, respectively. 
Table A4 Number of STDs diagnosed in the past year (Panel B)

\begin{tabular}{|c|c|c|c|c|c|c|}
\hline & Girls & $\begin{array}{l}\text { Girls: } \\
\text { White }\end{array}$ & $\begin{array}{l}\text { Girls: } \\
\text { Black }\end{array}$ & Boys & $\begin{array}{l}\text { Boys: } \\
\text { White }\end{array}$ & $\begin{array}{l}\text { Boys: } \\
\text { Black }\end{array}$ \\
\hline Self esteem & $\begin{array}{c}0.000 \\
(0.008)\end{array}$ & $\begin{array}{l}-0.004 \\
(0.003)\end{array}$ & $\begin{array}{l}0.003 \\
(0.006)\end{array}$ & $\begin{array}{l}0.006 \\
(0.006)\end{array}$ & $\begin{array}{c}0.000 \\
(0.002)\end{array}$ & $\begin{array}{c}0.001 \\
(0.006)\end{array}$ \\
\hline \multicolumn{7}{|l|}{$\begin{array}{l}\text { Family socio-economic } \\
\text { characteristics }\end{array}$} \\
\hline Income & $\begin{array}{c}0.000 \\
(0.000)\end{array}$ & $\begin{array}{c}0.000 \\
(0.000)\end{array}$ & $\begin{array}{l}0.000 \\
(0.001)\end{array}$ & $\begin{array}{c}0.000^{* *} \\
(0.000)\end{array}$ & $\begin{array}{c}0.000^{* * *} \\
(0.000)\end{array}$ & $\begin{array}{c}0.000 \\
(0.000)\end{array}$ \\
\hline \multicolumn{7}{|l|}{ Household size } \\
\hline Parent full-time job & $\begin{array}{c}-0.010^{*} \\
(0.006)\end{array}$ & $\begin{array}{r}-0.012^{*} \\
(0.007)\end{array}$ & $\begin{array}{l}-0.008 \\
(0.011)\end{array}$ & $\begin{array}{c}0.002 \\
(0.004)\end{array}$ & $\begin{array}{l}-0.001 \\
(0.004)\end{array}$ & $\begin{array}{c}0.010 \\
(0.011)\end{array}$ \\
\hline Economic stressor & $\begin{array}{l}-0.012 \\
(0.017)\end{array}$ & $\begin{array}{c}0.000 \\
(0.018)\end{array}$ & $\begin{array}{l}-0.050 \\
(0.043)\end{array}$ & $\begin{array}{c}0.006 \\
(0.010)\end{array}$ & $\begin{array}{c}0.006 \\
(0.009)\end{array}$ & $\begin{array}{l}-0.002 \\
(0.034)\end{array}$ \\
\hline Parents'education & $\begin{array}{c}0.002 \\
(0.022)\end{array}$ & $\begin{array}{c}0.018 \\
(0.026)\end{array}$ & $\begin{array}{l}-0.017 \\
(0.042)\end{array}$ & $\begin{array}{l}-0.005 \\
(0.015)\end{array}$ & $\begin{array}{l}-0.005 \\
(0.015)\end{array}$ & $\begin{array}{l}-0.005 \\
(0.037)\end{array}$ \\
\hline \multicolumn{7}{|l|}{ High school/Some college } \\
\hline College graduate (or over) & $\begin{array}{c}0.016 \\
(0.033)\end{array}$ & $\begin{array}{c}0.003 \\
(0.040)\end{array}$ & $\begin{array}{l}0.041 \\
(0.064)\end{array}$ & $\begin{array}{l}-0.016 \\
(0.026)\end{array}$ & $\begin{array}{l}-0.019 \\
(0.025)\end{array}$ & $\begin{array}{c}0.006 \\
(0.075)\end{array}$ \\
\hline Household composition & $\begin{array}{l}-0.003 \\
(0.036)\end{array}$ & $\begin{array}{l}-0.005 \\
(0.042)\end{array}$ & $\begin{array}{l}0.001 \\
(0.071)\end{array}$ & $\begin{array}{l}-0.016 \\
(0.026)\end{array}$ & $\begin{array}{l}-0.017 \\
(0.025)\end{array}$ & $\begin{array}{c}0.005 \\
(0.078)\end{array}$ \\
\hline \multicolumn{7}{|l|}{ Both residential parents } \\
\hline Parenting style & $\begin{array}{c}0.019 \\
(0.020)\end{array}$ & $\begin{array}{c}0.032 \\
(0.023)\end{array}$ & $\begin{array}{l}-0.000 \\
(0.042)\end{array}$ & $\begin{array}{c}0.011 \\
(0.013)\end{array}$ & $\begin{array}{c}0.002 \\
(0.013)\end{array}$ & $\begin{array}{c}0.032 \\
(0.035)\end{array}$ \\
\hline Family cohesion (3-15) & $\begin{array}{c}-0.013 * * \\
(0.006)\end{array}$ & $\begin{array}{c}-0.010^{* *} \\
(0.005)\end{array}$ & $\begin{array}{c}-0.015^{* *} \\
(0.008)\end{array}$ & $\begin{array}{c}-0.009 * * \\
(0.004)\end{array}$ & $\begin{array}{c}-0.008^{* * *} \\
(0.002)\end{array}$ & $\begin{array}{c}0.001 \\
(0.007)\end{array}$ \\
\hline Parental monitoring $(0-7)$ & $\begin{array}{c}0.008 \\
(0.006)\end{array}$ & $\begin{array}{c}0.003 \\
(0.006)\end{array}$ & $\begin{array}{l}0.019 \\
(0.012)\end{array}$ & $\begin{array}{l}-0.005 \\
(0.004)\end{array}$ & $\begin{array}{c}-0.006^{*} \\
(0.003)\end{array}$ & $\begin{array}{l}-0.000 \\
(0.010)\end{array}$ \\
\hline Family engagement (1-11) & $\begin{array}{l}-0.001 \\
(0.005)\end{array}$ & $\begin{array}{l}-0.001 \\
(0.005)\end{array}$ & $\begin{array}{l}-0.002 \\
(0.010)\end{array}$ & $\begin{array}{l}-0.005 \\
(0.003)\end{array}$ & $\begin{array}{l}-0.001 \\
(0.003)\end{array}$ & $\begin{array}{l}-0.011 \\
(0.008)\end{array}$ \\
\hline $\begin{array}{l}\text { Communication about sex } \\
\text { issues (7-28) }\end{array}$ & $\begin{array}{l}-0.001 \\
(0.002)\end{array}$ & $\begin{array}{l}-0.002 \\
(0.002)\end{array}$ & $\begin{array}{c}0.002 \\
(0.004)\end{array}$ & $\begin{array}{c}0.001 \\
(0.001)\end{array}$ & $\begin{array}{c}0.000 \\
(0.001)\end{array}$ & $\begin{array}{c}0.004 \\
(0.003)\end{array}$ \\
\hline $\begin{array}{l}\text { Ability to talk about sex } \\
\text { issues }(2-10)\end{array}$ & $\begin{array}{c}0.007 \\
(0.005)\end{array}$ & $\begin{array}{c}0.006 \\
(0.006)\end{array}$ & $\begin{array}{c}0.010 \\
(0.011)\end{array}$ & $\begin{array}{c}0.001 \\
(0.003)\end{array}$ & $\begin{array}{c}0.003 \\
(0.003)\end{array}$ & $\begin{array}{l}-0.003 \\
(0.009)\end{array}$ \\
\hline \multicolumn{7}{|c|}{ Continues in page below } \\
\hline
\end{tabular}




\begin{tabular}{|c|c|c|c|c|c|c|}
\hline \multicolumn{7}{|c|}{ Continues from page above } \\
\hline \multicolumn{7}{|l|}{ Religion value } \\
\hline Faily important & $\begin{array}{l}-0.018 \\
(0.053)\end{array}$ & $\begin{array}{l}-0.015 \\
(0.049)\end{array}$ & $\begin{array}{c}0.040 \\
(0.044)\end{array}$ & $\begin{array}{l}-0.009 \\
(0.027)\end{array}$ & $\begin{array}{l}-0.012 \\
(0.024)\end{array}$ & $\begin{array}{c}0.052 \\
(0.120)\end{array}$ \\
\hline Very important & $\begin{array}{l}-0.003 \\
(0.055)\end{array}$ & $\begin{array}{c}0.016 \\
(0.051)\end{array}$ & . & $\begin{array}{l}-0.010 \\
(0.028)\end{array}$ & $\begin{array}{l}-0.010 \\
(0.025)\end{array}$ & $\begin{array}{c}0.056 \\
(0.119)\end{array}$ \\
\hline \multicolumn{7}{|l|}{ Religion attendance } \\
\hline Once per month & $\begin{array}{c}0.024 \\
(0.030)\end{array}$ & $\begin{array}{c}0.007 \\
(0.029)\end{array}$ & $\begin{array}{c}0.116 \\
(0.103)\end{array}$ & $\begin{array}{c}0.015 \\
(0.016)\end{array}$ & $\begin{array}{c}0.006 \\
(0.015)\end{array}$ & $\begin{array}{c}0.072 \\
(0.065)\end{array}$ \\
\hline Once per week or more & $\begin{array}{c}0.001 \\
(0.031)\end{array}$ & $\begin{array}{l}-0.016 \\
(0.031)\end{array}$ & $\begin{array}{c}0.084 \\
(0.104)\end{array}$ & $\begin{array}{l}-0.000 \\
(0.017)\end{array}$ & $\begin{array}{l}-0.016 \\
(0.016)\end{array}$ & $\begin{array}{c}0.071 \\
(0.065)\end{array}$ \\
\hline \multicolumn{7}{|l|}{$\begin{array}{l}\text { Child demographic } \\
\text { charactheristics }\end{array}$} \\
\hline Age & $\begin{array}{l}-0.008 \\
(0.005)\end{array}$ & $\begin{array}{l}-0.006 \\
(0.006)\end{array}$ & $\begin{array}{l}-0.012 \\
(0.012)\end{array}$ & $\begin{array}{l}0.006^{*} \\
(0.003)\end{array}$ & $\begin{array}{c}0.004 \\
(0.003)\end{array}$ & $\begin{array}{c}0.008 \\
(0.010)\end{array}$ \\
\hline Ethnicity: Black & $\begin{array}{c}0.142 * * * \\
(0.024)\end{array}$ & . & . & $\begin{array}{c}0.060^{* * *} \\
(0.013)\end{array}$ & . & . \\
\hline \multicolumn{7}{|l|}{$\begin{array}{l}\text { Health and } \\
\text { attractiveness }\end{array}$} \\
\hline Poor health* disability & $\begin{array}{l}-0.086 \\
(0.095)\end{array}$ & $\begin{array}{c}0.003 \\
(0.114)\end{array}$ & $\begin{array}{l}-0.215 \\
(0.179)\end{array}$ & $\begin{array}{l}-0.049 \\
(0.066)\end{array}$ & $\begin{array}{l}-0.042 \\
(0.073)\end{array}$ & $\begin{array}{l}-0.055 \\
(0.151)\end{array}$ \\
\hline Obese & $\begin{array}{l}-0.022 \\
(0.043)\end{array}$ & $\begin{array}{l}-0.037 \\
(0.065)\end{array}$ & $\begin{array}{c}0.000 \\
(0.066)\end{array}$ & $\begin{array}{l}-0.026 \\
(0.028)\end{array}$ & $\begin{array}{l}0.005 \\
(0.029)\end{array}$ & $\begin{array}{l}-0.066 \\
(0.071)\end{array}$ \\
\hline Underweight & $\begin{array}{l}-0.014 \\
(0.033)\end{array}$ & $\begin{array}{c}0.014 \\
(0.033)\end{array}$ & $\begin{array}{l}-0.138 \\
(0.098)\end{array}$ & $\begin{array}{l}-0.002 \\
(0.022)\end{array}$ & $\begin{array}{l}-0.006 \\
(0.020)\end{array}$ & $\begin{array}{c}0.042 \\
(0.094)\end{array}$ \\
\hline Attractive (2-10) & $\begin{array}{l}0.013^{* *} \\
(0.005)\end{array}$ & $\begin{array}{c}0.009 \\
(0.006)\end{array}$ & $\begin{array}{l}0.022^{*} \\
(0.011)\end{array}$ & $\begin{array}{l}-0.001 \\
(0.004)\end{array}$ & $\begin{array}{l}-0.001 \\
(0.003)\end{array}$ & $\begin{array}{c}0.007 \\
(0.011)\end{array}$ \\
\hline \multicolumn{7}{|l|}{ School attainment } \\
\hline Grade (1-4) & $\begin{array}{l}-0.005 \\
(0.011) \\
\end{array}$ & $\begin{array}{l}-0.009 \\
(0.012) \\
\end{array}$ & $\begin{array}{c}0.015 \\
(0.027) \\
\end{array}$ & $\begin{array}{l}-0.007 \\
(0.007) \\
\end{array}$ & $\begin{array}{l}-0.006 \\
(0.006) \\
\end{array}$ & $\begin{array}{l}-0.001 \\
(0.021) \\
\end{array}$ \\
\hline \multicolumn{7}{|l|}{ IVs } \\
\hline Maternal support & $\begin{array}{c}1.875^{* * *} \\
(0.157)\end{array}$ & . & . & $\begin{array}{c}1.639^{* * *} \\
(0.153)\end{array}$ & . & \\
\hline Personality attractiveness & $\begin{array}{c}0.293 \\
(0.201)\end{array}$ & . & . & $\begin{array}{c}0.269 \\
(0.194)\end{array}$ & . & . \\
\hline Subjective obesity & $\begin{array}{c}-1.205^{* * *} \\
(0.148) \\
\end{array}$ & . & . & $\begin{array}{c}-0.990 * * * \\
(0.178) \\
\end{array}$ & . & . \\
\hline F-test: self-esteem & 50.41 & . & . & 41.37 & . & . \\
\hline Sargan overid: $p$ value & 0.09 & . & . & 0.80 & . & . \\
\hline Durbin-Wu-Hausman & 0.00 & 0.58 & 0.37 & 0.09 & 0.86 & 0.67 \\
\hline Observations & 2000 & 1426 & 574 & 1656 & 1282 & 374 \\
\hline
\end{tabular}

Note: All control variables included. The number of STDs diagnosed for the sample of girls and boys (first and fourth columns) have been estimated by instrumental variable estimation; the remaining models by OLS. Asterisks indicate significance at $* 0.1 * * 0.05 * * * 0.01$ levels, respectively. 
Table A5 Probability of never/ just occasionally used condom in the past 12 months

\begin{tabular}{|c|c|c|c|c|c|c|}
\hline & Girls & $\begin{array}{l}\text { Girls: } \\
\text { White }\end{array}$ & $\begin{array}{l}\text { Girls: } \\
\text { Black }\end{array}$ & Boys & $\begin{array}{l}\text { Boys: } \\
\text { White }\end{array}$ & $\begin{array}{l}\text { Boys: } \\
\text { Black }\end{array}$ \\
\hline Self esteem & $\begin{array}{l}-0.016^{*} \\
(0.010)\end{array}$ & $\begin{array}{l}-0.018 \\
(0.012)\end{array}$ & $\begin{array}{l}-0.086^{*} \\
(0.049)\end{array}$ & $\begin{array}{c}0.275^{* * * *} \\
(0.107)\end{array}$ & $\begin{array}{l}-0.005 \\
(0.014)\end{array}$ & $\begin{array}{l}-0.001 \\
(0.028)\end{array}$ \\
\hline $\begin{array}{l}\text { Self esteem^2 } \\
\text { Family socio-economic } \\
\text { characteristics }\end{array}$ & & . & & $\begin{array}{c}-0.007 * * * \\
(0.003)\end{array}$ & . & \\
\hline Income & $\begin{array}{l}-0.000 \\
(0.001)\end{array}$ & $\begin{array}{l}-0.000 \\
(0.001)\end{array}$ & $\begin{array}{l}-0.001 \\
(0.003)\end{array}$ & $\begin{array}{c}0.001 \\
(0.001)\end{array}$ & $\begin{array}{c}0.001 \\
(0.001)\end{array}$ & $\begin{array}{l}-0.002 \\
(0.003)\end{array}$ \\
\hline Household size & $\begin{array}{l}0.042 * \\
(0.023)\end{array}$ & $\begin{array}{c}0.007 \\
(0.031)\end{array}$ & $\begin{array}{c}0.076^{* *} \\
(0.036)\end{array}$ & $\begin{array}{l}-0.002 \\
(0.026)\end{array}$ & $\begin{array}{l}-0.010 \\
(0.031)\end{array}$ & $\begin{array}{c}0.005 \\
(0.052)\end{array}$ \\
\hline Parent full-time job & $\begin{array}{c}0.085 \\
(0.064)\end{array}$ & $\begin{array}{c}0.154^{* *} \\
(0.075)\end{array}$ & $\begin{array}{l}-0.079 \\
(0.136)\end{array}$ & $\begin{array}{c}0.047 \\
(0.072)\end{array}$ & $\begin{array}{c}0.025 \\
(0.080)\end{array}$ & $\begin{array}{c}0.086 \\
(0.175)\end{array}$ \\
\hline Economic stressor & $\begin{array}{c}0.019 \\
(0.084)\end{array}$ & $\begin{array}{c}0.016 \\
(0.111)\end{array}$ & $\begin{array}{c}0.037 \\
(0.135)\end{array}$ & $\begin{array}{c}0.086 \\
(0.103)\end{array}$ & $\begin{array}{c}0.067 \\
(0.126)\end{array}$ & $\begin{array}{c}0.115 \\
(0.184)\end{array}$ \\
\hline Parents'education & & & & & & \\
\hline High schoo & $\begin{array}{l}-0.062 \\
(0.127)\end{array}$ & $\begin{array}{l}-0.090 \\
(0.172)\end{array}$ & $\begin{array}{l}-0.039 \\
(0.197)\end{array}$ & $\begin{array}{c}0.172 \\
(0.175)\end{array}$ & $\begin{array}{c}0.205 \\
(0.204)\end{array}$ & $\begin{array}{c}0.075 \\
(0.361)\end{array}$ \\
\hline College g & $\begin{array}{l}-0.135 \\
(0.135)\end{array}$ & $\begin{array}{l}-0.207 \\
(0.181)\end{array}$ & $\begin{array}{c}0.066 \\
(0.219)\end{array}$ & $\begin{array}{c}0.053 \\
(0.182)\end{array}$ & $\begin{array}{c}0.147 \\
(0.211)\end{array}$ & $\begin{array}{l}-0.173 \\
(0.381)\end{array}$ \\
\hline Househ & & & & & & \\
\hline Both re & $\begin{array}{l}-0.013 \\
(0.077)\end{array}$ & $\begin{array}{c}0.051 \\
(0.099)\end{array}$ & $\begin{array}{l}-0.088 \\
(0.133)\end{array}$ & $\begin{array}{l}-0.054 \\
(0.089)\end{array}$ & $\begin{array}{l}-0.120 \\
(0.108)\end{array}$ & $\begin{array}{c}0.116 \\
(0.174)\end{array}$ \\
\hline Pare & & & & & & \\
\hline$(3-15)$ & $\begin{array}{l}-0.015 \\
(0.015)\end{array}$ & $\begin{array}{c}0.000 \\
(0.019)\end{array}$ & $\begin{array}{l}-0.009 \\
(0.034)\end{array}$ & $\begin{array}{l}-0.022 \\
(0.017)\end{array}$ & $\begin{array}{l}-0.026 \\
(0.020)\end{array}$ & $\begin{array}{l}-0.003 \\
(0.036)\end{array}$ \\
\hline Parent: & $\begin{array}{l}-0.006 \\
(0.022)\end{array}$ & $\begin{array}{l}-0.004 \\
(0.027)\end{array}$ & $\begin{array}{c}0.001 \\
(0.039)\end{array}$ & $\begin{array}{l}-0.013 \\
(0.025)\end{array}$ & $\begin{array}{l}-0.024 \\
(0.029)\end{array}$ & $\begin{array}{l}-0.005 \\
(0.051)\end{array}$ \\
\hline Family engagemen & $\begin{array}{l}-0.018 \\
(0.018)\end{array}$ & $\begin{array}{l}-0.020 \\
(0.022)\end{array}$ & $\begin{array}{l}-0.018 \\
(0.032)\end{array}$ & $\begin{array}{c}0.009 \\
(0.020)\end{array}$ & $\begin{array}{c}0.001 \\
(0.023)\end{array}$ & $\begin{array}{c}0.021 \\
(0.041)\end{array}$ \\
\hline $\begin{array}{l}\text { Communication about sex } \\
\text { issues (7-28) }\end{array}$ & $\begin{array}{c}0.020 * * * \\
(0.007)\end{array}$ & $\begin{array}{c}0.020^{* *} \\
(0.009)\end{array}$ & $\begin{array}{c}0.020 \\
(0.013)\end{array}$ & $\begin{array}{c}0.006 \\
(0.008)\end{array}$ & $\begin{array}{c}0.001 \\
(0.009)\end{array}$ & $\begin{array}{c}0.019 \\
(0.016)\end{array}$ \\
\hline $\begin{array}{l}\text { Ability to talk about sex } \\
\text { issues }(2-10)\end{array}$ & $\begin{array}{c}0.008 \\
(0.020)\end{array}$ & $\begin{array}{l}-0.004 \\
(0.026)\end{array}$ & $\begin{array}{c}0.038 \\
(0.033)\end{array}$ & $\begin{array}{l}-0.033 \\
(0.020)\end{array}$ & $\begin{array}{l}-0.032 \\
(0.024)\end{array}$ & $\begin{array}{l}-0.023 \\
(0.042)\end{array}$ \\
\hline
\end{tabular}




\begin{tabular}{|c|c|c|c|c|c|c|}
\hline \multicolumn{7}{|c|}{ Continues from page above } \\
\hline \multicolumn{7}{|l|}{ Religion value } \\
\hline Faily important & $\begin{array}{c}0.082 \\
(0.199)\end{array}$ & $\begin{array}{c}0.042 \\
(0.203)\end{array}$ & $\begin{array}{l}-0.136 \\
(0.139)\end{array}$ & $\begin{array}{c}-0.409^{* *} \\
(0.193)\end{array}$ & $\begin{array}{l}-0.294 \\
(0.206)\end{array}$ & $\begin{array}{l}-0.824 \\
(0.561)\end{array}$ \\
\hline Very important & $\begin{array}{c}0.212 \\
(0.207)\end{array}$ & $\begin{array}{c}0.147 \\
(0.213)\end{array}$ & . & $\begin{array}{l}-0.268 \\
(0.200)\end{array}$ & $\begin{array}{l}-0.074 \\
(0.216)\end{array}$ & $\begin{array}{r}-0.934 * \\
(0.558)\end{array}$ \\
\hline \multicolumn{7}{|l|}{ Religion attendance } \\
\hline Once per month & $\begin{array}{c}0.055 \\
(0.115)\end{array}$ & $\begin{array}{c}0.055 \\
(0.123)\end{array}$ & $\begin{array}{l}-0.156 \\
(0.348)\end{array}$ & $\begin{array}{c}0.127 \\
(0.113)\end{array}$ & $\begin{array}{c}0.109 \\
(0.122)\end{array}$ & $\begin{array}{c}0.055 \\
(0.308)\end{array}$ \\
\hline Once per week or more & $\begin{array}{l}-0.023 \\
(0.121)\end{array}$ & $\begin{array}{c}0.046 \\
(0.132)\end{array}$ & $\begin{array}{l}-0.362 \\
(0.356)\end{array}$ & $\begin{array}{l}0.012 \\
(0.118)\end{array}$ & $\begin{array}{l}-0.031 \\
(0.131)\end{array}$ & $\begin{array}{l}-0.020 \\
(0.306)\end{array}$ \\
\hline \multicolumn{7}{|l|}{$\begin{array}{l}\text { Child demographic } \\
\text { charactheristics }\end{array}$} \\
\hline Age & $\begin{array}{c}0.043^{* *} \\
(0.020)\end{array}$ & $\begin{array}{r}0.049^{* *} \\
(0.024)\end{array}$ & $\begin{array}{c}0.015 \\
(0.037)\end{array}$ & $\begin{array}{c}0.132 * * * \\
(0.024)\end{array}$ & $\begin{array}{c}0.139 * * * \\
(0.028)\end{array}$ & $\begin{array}{r}0.122 * * \\
(0.049)\end{array}$ \\
\hline Ethnicity: Black & $\begin{array}{c}-0.371 * * * \\
(0.079)\end{array}$ & . & . & $\begin{array}{c}-0.510^{* * *} \\
(0.090)\end{array}$ & . & \\
\hline $\begin{array}{l}\text { Health and } \\
\text { attractiveness }\end{array}$ & & & & & & \\
\hline Poor health* disability & $\begin{array}{c}0.318 \\
(0.369)\end{array}$ & $\begin{array}{c}0.298 \\
(0.502)\end{array}$ & $\begin{array}{c}0.265 \\
(0.534)\end{array}$ & $\begin{array}{l}-0.081 \\
(0.441)\end{array}$ & $\begin{array}{l}-0.326 \\
(0.577)\end{array}$ & $\begin{array}{c}0.236 \\
(0.743)\end{array}$ \\
\hline Obese & $\begin{array}{c}0.044 \\
(0.163)\end{array}$ & $\begin{array}{c}0.454 \\
(0.301)\end{array}$ & $\begin{array}{l}-0.227 \\
(0.217)\end{array}$ & $\begin{array}{l}-0.204 \\
(0.207)\end{array}$ & $\begin{array}{l}-0.194 \\
(0.265)\end{array}$ & $\begin{array}{l}-0.151 \\
(0.342)\end{array}$ \\
\hline Underweight & $\begin{array}{l}-0.154 \\
(0.124)\end{array}$ & $\begin{array}{l}-0.214 \\
(0.136)\end{array}$ & $\begin{array}{c}0.079 \\
(0.301)\end{array}$ & $\begin{array}{l}-0.052 \\
(0.156)\end{array}$ & $\begin{array}{l}-0.052 \\
(0.166)\end{array}$ & $\begin{array}{l}-0.242 \\
(0.505)\end{array}$ \\
\hline Attractive (2-10) & $\begin{array}{c}0.016 \\
(0.020)\end{array}$ & $\begin{array}{c}0.026 \\
(0.025)\end{array}$ & $\begin{array}{c}0.008 \\
(0.036)\end{array}$ & $\begin{array}{l}0.013 \\
(0.025)\end{array}$ & $\begin{array}{c}0.020 \\
(0.029)\end{array}$ & $\begin{array}{l}-0.007 \\
(0.055)\end{array}$ \\
\hline School attainment & & & & & & \\
\hline Grade (1-4) & $\begin{array}{l}-0.002 \\
(0.042) \\
\end{array}$ & $\begin{array}{c}0.015 \\
(0.050) \\
\end{array}$ & $\begin{array}{c}0.006 \\
(0.087) \\
\end{array}$ & $\begin{array}{r}0.020 \\
(0.047) \\
\end{array}$ & $\begin{array}{r}0.004 \\
(0.053) \\
\end{array}$ & $\begin{array}{c}0.088 \\
(0.106) \\
\end{array}$ \\
\hline
\end{tabular}

\begin{tabular}{|c|c|c|c|c|c|c|}
\hline \multicolumn{7}{|l|}{ IVs } \\
\hline Maternal support & & . & $\begin{array}{c}2.533 * * * \\
(0.288)\end{array}$ & . & . & \\
\hline Personality attractiveness & & 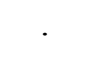 & $\begin{array}{c}0.016 \\
0.373\end{array}$ & & . & \\
\hline Subjective obesity & & . & $\begin{array}{c}(0.3 / 3) \\
-1.028 * * * \\
(0.282)\end{array}$ & & . & \\
\hline F-test: self-esteem & & - & 21.75 & . & . & . \\
\hline Sargan overid: $p$ value & & . & 0.16 & · & . & . \\
\hline Durbin-Wu-Hausman & & 0.97 & 0.09 & 0.12 & 0.14 & 0.65 \\
\hline Observations & 1,831 & 1,316 & 515 & 1,460 & 1119 & 341 \\
\hline
\end{tabular}

Note: All control variables included. All models have been estimated by probit model except the probability for black girls of never/just occasionally use condom (third column) which has been estimated by a probit model with endogenous regressors using maximum likelihood estimator. Marginal effects reported. Asterisks indicate significance at $* 0.1 * * 0.05 * * * 0.01$ levels, respectively. 
Table A6 Probability of never/ just occasionally used any birth control method in the past 12 months

\begin{tabular}{|c|c|c|c|c|c|c|}
\hline & Girls & $\begin{array}{l}\text { Girls: } \\
\text { White }\end{array}$ & $\begin{array}{l}\text { Girls: } \\
\text { Black }\end{array}$ & Boys & $\begin{array}{l}\text { Boys: } \\
\text { White }\end{array}$ & $\begin{array}{l}\text { Boys: } \\
\text { Black }\end{array}$ \\
\hline Self esteem & $\begin{array}{l}-0.001 \\
(0.010)\end{array}$ & $\begin{array}{l}-0.005 \\
(0.012)\end{array}$ & $\begin{array}{l}-0.096^{*} \\
(0.053)\end{array}$ & $\begin{array}{l}-0.021 \\
(0.013)\end{array}$ & $\begin{array}{l}-0.025 \\
(0.015)\end{array}$ & $\begin{array}{l}-0.013 \\
(0.028)\end{array}$ \\
\hline \multicolumn{7}{|l|}{$\begin{array}{l}\text { Family socio-economic } \\
\text { characteristics }\end{array}$} \\
\hline Income & $\begin{array}{c}-0.004 * * * \\
(0.001)\end{array}$ & $\begin{array}{c}-0.004 * * * \\
(0.001)\end{array}$ & $\begin{array}{l}-0.004 \\
(0.003)\end{array}$ & $\begin{array}{l}-0.000 \\
(0.001)\end{array}$ & $\begin{array}{l}-0.000 \\
(0.001)\end{array}$ & $\begin{array}{l}-0.001 \\
(0.003)\end{array}$ \\
\hline Household size & $\begin{array}{c}0.068^{* * *} \\
(0.024)\end{array}$ & $\begin{array}{c}0.036 \\
(0.033)\end{array}$ & $\begin{array}{c}0.121^{* * *} \\
(0.038)\end{array}$ & $\begin{array}{c}0.037 \\
(0.027)\end{array}$ & $\begin{array}{c}0.024 \\
(0.033)\end{array}$ & $\begin{array}{r}0.048 \\
(0.052)\end{array}$ \\
\hline Parent full-time job & $\begin{array}{c}0.063 \\
(0.069)\end{array}$ & $\begin{array}{c}0.072 \\
(0.081)\end{array}$ & $\begin{array}{l}0.003 \\
(0.145)\end{array}$ & $\begin{array}{l}-0.031 \\
(0.076)\end{array}$ & $\begin{array}{l}-0.012 \\
(0.087)\end{array}$ & $\begin{array}{l}-0.116 \\
(0.173)\end{array}$ \\
\hline Economic stressor & $\begin{array}{c}0.066 \\
(0.089)\end{array}$ & $\begin{array}{c}0.044 \\
(0.119)\end{array}$ & $\begin{array}{l}0.107 \\
(0.143)\end{array}$ & $\begin{array}{l}-0.062 \\
(0.107)\end{array}$ & $\begin{array}{l}-0.108 \\
(0.134)\end{array}$ & $\begin{array}{c}0.007 \\
(0.183)\end{array}$ \\
\hline \multicolumn{7}{|l|}{ Parents'education } \\
\hline High school/Some college & $\begin{array}{l}-0.123 \\
(0.127)\end{array}$ & $\begin{array}{c}-0.320 * \\
(0.169)\end{array}$ & $\begin{array}{c}0.141 \\
(0.210)\end{array}$ & $\begin{array}{c}0.118 \\
(0.188)\end{array}$ & $\begin{array}{c}0.059 \\
(0.222)\end{array}$ & $\begin{array}{c}0.195 \\
(0.365)\end{array}$ \\
\hline College graduate (or over) & $\begin{array}{l}-0.231^{*} \\
(0.139)\end{array}$ & $\begin{array}{c}-0.486^{* * *} \\
(0.183)\end{array}$ & $\begin{array}{l}0.201 \\
(0.236)\end{array}$ & $\begin{array}{c}0.028 \\
(0.195)\end{array}$ & $\begin{array}{l}-0.020 \\
(0.229)\end{array}$ & $\begin{array}{r}0.167 \\
(0.385)\end{array}$ \\
\hline Household c & & & & & & \\
\hline Both residential parents & $\begin{array}{l}-0.080 \\
(0.082)\end{array}$ & $\begin{array}{l}-0.064 \\
(0.106)\end{array}$ & $\begin{array}{l}-0.110 \\
(0.143)\end{array}$ & $\begin{array}{l}-0.017 \\
(0.094)\end{array}$ & $\begin{array}{l}-0.049 \\
(0.117)\end{array}$ & $\begin{array}{r}0.065 \\
(0.173)\end{array}$ \\
\hline \multicolumn{7}{|l|}{ Parenting style } \\
\hline Family cohesion (3-15) & $\begin{array}{c}-0.036^{* *} \\
(0.016)\end{array}$ & $\begin{array}{l}-0.027 \\
(0.020)\end{array}$ & $\begin{array}{l}0.007 \\
(0.035)\end{array}$ & $\begin{array}{c}0.011 \\
(0.018)\end{array}$ & $\begin{array}{l}-0.003 \\
(0.021)\end{array}$ & $\begin{array}{c}0.042 \\
(0.037)\end{array}$ \\
\hline Parental monitoring $(0-7)$ & $\begin{array}{c}-0.057 * * \\
(0.023)\end{array}$ & $\begin{array}{c}-0.068^{* *} \\
(0.029)\end{array}$ & $\begin{array}{l}-0.033 \\
(0.042)\end{array}$ & $\begin{array}{l}-0.036 \\
(0.026)\end{array}$ & $\begin{array}{l}-0.010 \\
(0.032)\end{array}$ & $\begin{array}{l}-0.084 \\
(0.051)\end{array}$ \\
\hline Family engagement (1-11) & $\begin{array}{l}-0.020 \\
(0.019)\end{array}$ & $\begin{array}{l}-0.030 \\
(0.023)\end{array}$ & $\begin{array}{l}-0.008 \\
(0.035)\end{array}$ & $\begin{array}{l}-0.008 \\
(0.021)\end{array}$ & $\begin{array}{l}-0.029 \\
(0.026)\end{array}$ & $\begin{array}{c}0.036 \\
(0.041)\end{array}$ \\
\hline $\begin{array}{l}\text { Communication about sex } \\
\text { issues (7-28) }\end{array}$ & $\begin{array}{r}0.019^{* *} \\
(0.008)\end{array}$ & $\begin{array}{c}0.021 * * \\
(0.010)\end{array}$ & $\begin{array}{l}0.012 \\
(0.014)\end{array}$ & $\begin{array}{l}-0.006 \\
(0.008)\end{array}$ & $\begin{array}{l}-0.002 \\
(0.010)\end{array}$ & $\begin{array}{l}-0.016 \\
(0.016)\end{array}$ \\
\hline $\begin{array}{l}\text { Ability to talk about sex } \\
\text { issues }(2-10)\end{array}$ & $\begin{array}{l}-0.020 \\
(0.021)\end{array}$ & $\begin{array}{l}-0.014 \\
(0.027)\end{array}$ & $\begin{array}{l}-0.024 \\
(0.036)\end{array}$ & $\begin{array}{c}0.001 \\
(0.022)\end{array}$ & $\begin{array}{c}0.017 \\
(0.026)\end{array}$ & $\begin{array}{l}-0.035 \\
(0.042)\end{array}$ \\
\hline
\end{tabular}




\begin{tabular}{|c|c|c|c|c|c|c|}
\hline \multicolumn{7}{|c|}{ Continues from page above } \\
\hline \multicolumn{7}{|l|}{ Religion value } \\
\hline Faily important & $\begin{array}{l}-0.059 \\
(0.220)\end{array}$ & $\begin{array}{l}-0.111 \\
(0.224)\end{array}$ & $\begin{array}{c}0.003 \\
(0.149)\end{array}$ & $\begin{array}{l}-0.069 \\
(0.197)\end{array}$ & $\begin{array}{l}-0.106 \\
(0.212)\end{array}$ & $\begin{array}{c}0.126 \\
(0.571)\end{array}$ \\
\hline Very important & $\begin{array}{l}0.008 \\
(0.227)\end{array}$ & $\begin{array}{l}-0.038 \\
(0.234)\end{array}$ & . & $\begin{array}{l}0.075 \\
(0.204)\end{array}$ & $\begin{array}{c}0.105 \\
(0.223)\end{array}$ & $\begin{array}{c}0.059 \\
(0.569)\end{array}$ \\
\hline \multicolumn{7}{|l|}{ Religion attendance } \\
\hline Once per month & $\begin{array}{l}-0.023 \\
(0.120)\end{array}$ & $\begin{array}{c}0.008 \\
(0.132)\end{array}$ & $\begin{array}{l}-0.294 \\
(0.352)\end{array}$ & $\begin{array}{l}-0.153 \\
(0.119)\end{array}$ & $\begin{array}{l}-0.168 \\
(0.131)\end{array}$ & $\begin{array}{l}-0.138 \\
(0.309)\end{array}$ \\
\hline Once per week or more & $\begin{array}{l}0.008 \\
(0.127)\end{array}$ & $\begin{array}{c}0.123 \\
(0.141)\end{array}$ & $\begin{array}{l}-0.434 \\
(0.362)\end{array}$ & $\begin{array}{l}-0.117 \\
(0.124)\end{array}$ & $\begin{array}{l}-0.095 \\
(0.139)\end{array}$ & $\begin{array}{l}-0.224 \\
(0.307)\end{array}$ \\
\hline \multicolumn{7}{|l|}{$\begin{array}{l}\text { Child demographic } \\
\text { charactheristics }\end{array}$} \\
\hline Age & $\begin{array}{l}-0.014 \\
(0.021)\end{array}$ & $\begin{array}{l}-0.012 \\
(0.026)\end{array}$ & $\begin{array}{l}-0.033 \\
(0.040)\end{array}$ & $\begin{array}{c}0.084 * * * \\
(0.025)\end{array}$ & $\begin{array}{c}0.065^{* *} \\
(0.030)\end{array}$ & $\begin{array}{r}0.119 * * \\
(0.049)\end{array}$ \\
\hline Ethnicity: Black & $\begin{array}{c}0.039 \\
(0.082)\end{array}$ & & . & $\begin{array}{c}0.319 * * * \\
(0.093)\end{array}$ & & \\
\hline \multicolumn{7}{|l|}{$\begin{array}{l}\text { Health and } \\
\text { attractiveness }\end{array}$} \\
\hline Poor health* disability & $\begin{array}{l}0.619^{*} \\
(0.354)\end{array}$ & $\begin{array}{c}0.754 \\
(0.476)\end{array}$ & $\begin{array}{c}0.513 \\
(0.561)\end{array}$ & $\begin{array}{c}0.067 \\
(0.468)\end{array}$ & $\begin{array}{l}-0.211 \\
(0.661)\end{array}$ & $\begin{array}{c}0.333 \\
(0.743)\end{array}$ \\
\hline Obese & $\begin{array}{c}0.415^{* * *} \\
(0.161)\end{array}$ & $\begin{array}{c}0.902 * * * \\
(0.282)\end{array}$ & $\begin{array}{c}0.037 \\
(0.231)\end{array}$ & $\begin{array}{l}-0.262 \\
(0.220)\end{array}$ & $\begin{array}{l}-0.016 \\
(0.278)\end{array}$ & $\begin{array}{l}-0.607 \\
(0.374)\end{array}$ \\
\hline Underweight & $\begin{array}{l}-0.060 \\
(0.135)\end{array}$ & $\begin{array}{l}-0.065 \\
(0.152)\end{array}$ & $\begin{array}{l}-0.153 \\
(0.318)\end{array}$ & $\begin{array}{l}-0.015 \\
(0.174)\end{array}$ & $\begin{array}{l}-0.065 \\
(0.191)\end{array}$ & $\begin{array}{c}0.351 \\
(0.457)\end{array}$ \\
\hline Attractive (2-10) & $\begin{array}{l}-0.014 \\
(0.022)\end{array}$ & $\begin{array}{l}-0.007 \\
(0.027)\end{array}$ & $\begin{array}{l}-0.002 \\
(0.039)\end{array}$ & $\begin{array}{l}0.020 \\
(0.027)\end{array}$ & $\begin{array}{c}0.033 \\
(0.032)\end{array}$ & $\begin{array}{c}0.002 \\
(0.055)\end{array}$ \\
\hline School attainment & & & & & & \\
\hline Grade (1-4) & $\begin{array}{c}-0.201 * * * \\
(0.045) \\
\end{array}$ & $\begin{array}{c}-0.215^{* * *} \\
(0.053) \\
\end{array}$ & $\begin{array}{l}-0.081 \\
(0.092) \\
\end{array}$ & $\begin{array}{c}-0.105^{* *} \\
(0.050) \\
\end{array}$ & $\begin{array}{l}-0.080 \\
(0.058) \\
\end{array}$ & $\begin{array}{l}-0.172 \\
(0.106) \\
\end{array}$ \\
\hline
\end{tabular}

\begin{tabular}{|c|c|c|c|c|c|c|}
\hline \multicolumn{7}{|l|}{ IVs } \\
\hline Maternal support & & · & $\begin{array}{c}2.533 * * * \\
(0.288)\end{array}$ & . & & . \\
\hline Personality attractiveness & & . & 0.016 & . & - & \\
\hline Subjective obesity & & . & $\begin{array}{c}(0.373) \\
-1.028^{* * *} \\
(0.282)\end{array}$ & . & . & . \\
\hline F-test: self-esteem & & . & 22.66 & . & . & . \\
\hline Sargan overid: $p$ value & & . & 0.16 & . & . & \\
\hline Durbin-Wu-Hausman & & 0.97 & 0.04 & 0.51 & 0.50 & 0.98 \\
\hline Observations & 1830 & 1316 & 514 & 1448 & 1110 & 338 \\
\hline
\end{tabular}

Note: All control variables included. All models have been estimated by probit model except the probability for black girls of never/just occasionally use any birth control method (third column) which has been estimated by a probit model with endogenous regressors using maximum likelihood estimator. Marginal effects reported. Asterisks indicate significance at * $0.1 * * 0.05 * * * 0.01$ levels, respectively. 